\title{
Kernos
}

Revue internationale et pluridisciplinaire de religion grecque antique

19 | 2006

Varia

\section{Epigraphic Bulletin for Greek Religion 2003 (EBGR 2003)}

Angelos Chaniotis and Joannis Mylonopoulos

\section{(2) OpenEdition}

\section{Journals}

Electronic version

URL: https://journals.openedition.org/kernos/469

DOI: 10.4000/kernos.469

ISSN: 2034-7871

\section{Publisher}

Centre international d'étude de la religion grecque antique

\section{Printed version}

Date of publication: 1 January 2006

Number of pages: 343-390

ISSN: 0776-3824

\section{Electronic reference}

Angelos Chaniotis and Joannis Mylonopoulos, "Epigraphic Bulletin for Greek Religion 2003 (EBGR 2003)", Kernos [Online], 19 | 2006, Online since 18 June 2011, connection on 24 August 2022. URL http://journals.openedition.org/kernos/469 ; DOl: https://doi.org/10.4000/kernos.469 


\title{
Epigraphic Bulletin for Greek Religion 2003 (EBGR 2003)
}

\author{
To Henk Versnel on the occasion of his $70 t h$ birthday.
}

The 16th issue of the Epigraphic Bulletin for Greek Religion presents a representative part of epigraphic publications of the year 2003 and many additions to EBGR 2002 and to earlier issues. Unfortunately, the heavy - but luckily temporary - duties of one of the editors in the Rectorate in Heidelberg (AC) and the move of the second editor from Vienna to Erfurt (JM) have not allowed us to present in this issue summaries of all the relevant books and articles. In order to avoid a substantial delay in the publication of Kernos we have decided to postpone the presentation of these publications, including numerous corpora.

Nevertheless, the 190 lemmata presented here are a representative segment of epigraphical contributions to the study of Greek religion. The most significant new text is the Greek version of an oracle of Apollon Klarios from Pisidia, hitherto known only from its widely disseminated Latin versions (116). According to S. Mitchell's attractive hypothesis, this text is an interpretation (exegesis) of the famous theosophical oracle of Oinoanda that explains the nature of god (SEG XXVII 933), attempting a reconciliation of traditional religion with the rising popularity of monotheistic beliefs. The exegesis of this oracle recommended the worship of the traditional gods, although they ranked below the highest god (Theos Hypsistos). A nice illustration of the conflict between traditional pagan religion and Christianity in Late Antiquity is a Christian graffito on the back of the head of the statue of Oecumenius, a (pagan?) governor of Karia in late fourth-century Aphrodisias (161)

The emperor cult in the Roman East continues to attract a lot of attention (e.g., 13. 22. 70. 79. 159. 169. 189; the volume H. CANCIK - K. HITZL [eds], Die Praxis der Herrscherverehrung in Rom und seinen Provinzen, Akten der Tagung in Blaubeuren vom 4. bis zum 6. April 2002, Tübingen, 2003, will be presented in EBGR 2004). A very interesting text from the area of Phellos (153) lists the contributions made by priests for the celebration of a festival, possibly a sort of summa bonoraria.

Among the new inscriptions we single out a new Orphic lamella from Macedonia which seems to address Plouton as lord of the Underworld (68) and an important new piece of evidence for the mystery cult at Samothrake (83). New finds continue to contribute to the study of magic; we single out a group of interesting curse tablets from Pydna (32), one of them using emotional language (for this phenomenon see H.S. VERSNEL, "Sachliche Sprache und emotionale Sprache in griechischen und römischen Fluch-Texten", in A. Kneppe - D. Metzler [eds], Die emotionale Dimension antiker Religiosität, Münster, 2003, p. 87-116, which will summarised in the next issue of $E B G R$ ), and an amulet found near the Lake Garda (26) aiming at protecting its owner from the symptoms of epilepsy. The epitaph of a priest of Apollon at Oinoanda stresses the affinity of his divinatory practices with those in Delphi (115); an oracle from the same city probably instructed the worship of Asklepios (115). One of the most intriguing new texts is a praise of Mes Axiottenos from Lydia (99); it illustrates

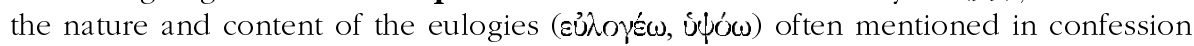


inscriptions and related texts. Among the dedications we single out an unusual anatomical (or apotropaic?) dedication to Poseidon in Macedonia (138): a woman dedicated a relief depicting male genitals.

The principles explained in Kernos 4 (1991), p. 287-288 and 7 (1994), p. 287 also apply to this issue. Abbreviations which are not included in the list of abbreviations are those of L'Année Philologique and J.H.M. STrubBe (ed.), Supplementum Epigraphicum Graecum. Consolidated Index for Volumes XXXVI-XLV (1986-1995), Amsterdam, 1999, as well as of later volumes of the SEG. If not otherwise specified, dates are BC. We are very much obliged to cand. phil. Benedict BECKELD for improving the English text.

We dedicate this issue to H.S. Versnel whose studies on ancient religion and his contributions to the methodology of religious studies have been a source of inspiration. $[\mathrm{AC}]$

\begin{tabular}{|c|c|}
\hline BIWK & $\begin{array}{l}\text { G. PETZL, Die Beichtinschriften Westkleinasiens, Bonn, } 1994 \\
(E A, 22) \text {. }\end{array}$ \\
\hline Excavating Classical Culture & $\begin{array}{l}\text { M. STAMATOPOUlou - M. YEROUlanou (eds), Excavating } \\
\text { Classical Culture. Recent Archaeological Discoveries in Greece, } \\
\text { Oxford, } 2002 \text {. }\end{array}$ \\
\hline Influenze vicino-orientali & $\begin{array}{l}\text { S. RIBICHINI - M. ROCCHI - P. XELLA (eds), La questione delle } \\
\text { influenze vicino-orientali sulla religione greca. Stato degli studi } \\
\text { e prospettive della ricerca. Atti del Colloquio Internazionale, } \\
\text { Roma, 20-22 maggio 1999, Rome, } 2001 \text {. }\end{array}$ \\
\hline JORDAN, $S G D$ & $\begin{array}{l}\text { D.R. JORDAN, "Survey of Greek Defixiones not Included in the } \\
\text { Special Corpora", GRBS } 26 \text { (1985), p. 1-81. }\end{array}$ \\
\hline Jubilaeus $\mathrm{V}$ & $\begin{array}{l}\text { K. BOSHNAKOV - D. BOTEVA (eds), Jubilaeus V. Sbornik v čest } \\
\text { na prof. Margarita Tačeva, Sofia, } 2002 .\end{array}$ \\
\hline Kallisteuma & 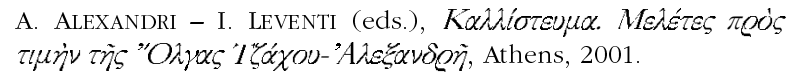 \\
\hline Latreies & 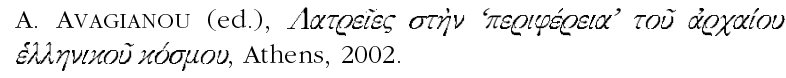 \\
\hline The Roman and Late Roman City & $\begin{array}{l}\text { L. RUSEVA-SLOKOSKA - V. DINCHEV (eds), The Roman and Late } \\
\text { Roman City: The International Conference, Veliko Târnovo, 26- } \\
\text { 30 July 20OO, Sofia, } 2002 \text {. }\end{array}$ \\
\hline Studia Karayotov & $\begin{array}{l}\text { Studia in honorem Ivani Karayotov, Bourgas, } 2002 \text { (Bulletin du } \\
\text { Musée National de Bourgas, 4). }\end{array}$ \\
\hline Studies Skydsgaard & $\begin{array}{l}\text { K. ASCANI et al. (eds), Ancient History Matters. Studies Presented } \\
\text { to Jens Erik Skydsgaard on His Seventieth Birthday, Rome, } 2002 .\end{array}$ \\
\hline Stuttgarter Kolloquium 7 & $\begin{array}{l}\text { E. OLSHAUSEN - H. SONNABEND (eds), Stuttgarter Kolloquium } \\
\text { zur historischen Geographie des Altertums 7, 1999. Zu Wasser } \\
\text { und zu Land. Verkehrswege in der antiken Welt, Stuttgart, } 2002 .\end{array}$ \\
\hline
\end{tabular}

\section{Select Topics}

Geographical areas (in the sequence adopted by $S E G$ )

Attica: 3. 10-12. 27. 29. 37. 47-48. 89. 94. 98. 120. 129. 154. 158. 162. 184. Boiotia Oropos: 97; Thebes: 112. Peloponnesos: 118. Korinthia: Isthmos: 24. 108. Kleonaia: 
Nemea: 108. 114. Argolis: Argos: 4. Kynouria: 131. Epidauria: Epidauros: 56.104. 108. 134. Messenia: Messene: 130. Lakonia: Amyklai: 150; Sparta: 25. Elis: Olympia: 108. 181. Delphi: 37. 73. 93. 101. 108. 115. 134. 145-146. 179. 181. Akarnania: Aktion: 34. Ionian Islands: Ithake: 85; Korkyra: 81. Thessaly: 7. 135. 187-188; Aiginion: 186; Melitaia: 35; Metropolis: 74-75; Pherai: 6. Epeiros: Dodona: 53. 181; Passaron: 86. Macedonia: 68. 108. 117; Amphipolis: 83; Dion: 125. 132; Kallindoia: 159; Naousa 138; Pella: 95; Philippi: 173; Sandanski: 5; Skydra: 67. Thrace: 45. 160; Agathopolis: 9; Augusta Traiana: 23; Kabyle: 54; Kallatis: 8; Maroneia: 28; Mesambria: 84; Philippopolis: 154; Trajanopolis: 190. Moesia: 45. 124. 160; Histria: 113; Nikopolis: 58. 96. North Shore of the Black Sea: Berezan: 123; Bosporan Kingdom: 61; Chersonesos 65. 91; Leuke: 148; Olbia: 6. 171; Tyras: 30. Delos: 11. 21. 49. 66. 136. 172. Rhodes: 40. 128; Lindos: 80. Lesbos: Eresos: 79. Thera: 157. Melos: 79. Tenos: 90. Paros: 111. Kos: 18. 182-183. Thasos: 63. 126. Samothrake: 18. 28. 72. 83. 107. 135. 190. Crete: 133. 174; Gortyn: 77. 105-106; Lebena: 110; Lisos: 109. Euboia: Styra: 140. Italy: 14. 26. 38. Sicily: 102-103. 180; Syracuse: 55. Britain: 87. Karia: 69; Alabanda: 168; Aphrodisias: 161; Halikarnassos: 76; Herakleia under Latmos: 185; Knidos: 143; Lagina: 149 176; Loryma: 69; Mylasa: 134; Panamara: 175; Stratonikeia: 27. 57. Ionia: Ephesos: 22. 27. 162. 166; Klaros: 53; Kolophon: 53; Magnesia on the Maeander: 85. 147; Miletos 27. 46. 64; Smyrna: 22. 70. Troas: Ilion: 121. Lydia: 99. 141-142. Mysia: Kyzikos: 22 Miletoupolis: 31; Pergamon: 119; Silandos: 100. Phrygia: 41. 71. 141. 167; Hierapolis: 144. Pisidia: Melli: 116; Pednelissos: 13. Pamphylia: Side: 165. Lykia: Arykanda: 152; Oinoanda: 115; Patara: 88; Phellos: 153; Termessos: 169. Lykaonia: 170. Killikia: Aigeai: 189. Cyprus: 78. Syria: 1. 50; Antiocheia: 72. Palaestina: 2. 127. Arabia: 122. 177. North Africa: Kyrene/Kyrenaika: 44. 104; Leptis Magna: 43. 139; Egypt: 15. 19 33. 82. 92.151

Abrasax: 2. 60

afterlife: 6-7. 68.71. 83. 143

agonistic festival, and women: 42 ; see also festival altar: 21. 66. 69. 118. 125. 131. 139. 167-168. 170. 190

amphictyony; 118. 181. 188

amulet: 2. 14.26

anatomical dedication: 111. 138

animal, sacred: 118

arkteia: 42.48

association, cult: 8. 11. 18. 117. 123. 139. 141. 166, 172-173

asylia: 18. 85. 147

baetyl: 81

banquet: 11. 27. 150. 153

burial: 19; see also funerary cult

calendar: 137. 185. 186

cave: 8

Christians, Christianity: 161

chthonic cult: 7

clothes, of priests: 115

confession inscription: 56. 99. 142 
cosmology: 6. 19

crown: 8. 64. 100

cult, continuity: 178; exclusion from: 42; founder of: 31; introduction of: 67. 158. 169; private: 66; reform: 57; regulation: 27.69 .128 .183 ; table: 44. 114; transfer: 11; see also emperor cult, royal cult

cult personnel: agonothetes: 18. 70. 160; alektris: 42; archiereia: 160; archiereus, of the city emperor cult: 13. 23. 58. 79; archiereus of the provincial emperor cult: 24 (Achaia). 70 (Asia); archieristas: 40; arktos: 42; arrhephoros: 42; Asiarches: 70; diakonos: 141; ergastinai: 3; hiereia: 187; hiereus: 8. 79. 115. 141; hiereus heptaterikos: 188; hierodoulos: 141; hieromnemon: 149; hieronomos: 160; hieropoios: 40. 136. 160. 182; hieros/hiera: 141. 160; hierothytes: 40. 180; hydrophoros: 42; hymnodos: 58. 70. 160; kanephoros: 42; kleidophoros: 176; lampadarchos: 111; napoios: 111; neokoros: 70. 111. 141. 160; neopoiai: 9; panegyriarchos/es: 13. 160; prophetes: 64. 141; stephanoplokos: 8; theorodokos: 4. 108; theoros: 18. 135. 180; zakoros: 160

curse, curse tablet: 12. 72. 87. 120. 171; see also funerary imprecation

Cypriots: 11

dedication: 34. 89. 106. 136; after the death of a relative: 139; after war: 61. 86; anatomical: 111; by cult personnel after the term of office: 13.125 ; by family members: 139; by soldiers: 122; for the well-being of the master: 142; label on d.: 109; of persons: 41. 180; removal of: 80. 89; restoration of: 119; selling of: 80; thanksgiving d.: 33. 95. 122. 139; upon divine command: 177

deities: Agra: 158. Amphiaraos: 97. 110. Aphrodite: 44. 47. 76. 78. 133. 157; Hegemone 129; Sebasmiotate 177. Apollon: 9. 34. 44. 53-54. 61. 71. 73. 75.84 110. 113-115. 123. 136. 145-146. 150. 153-154. 165. 181; Agyieus 81; Archegetes 76; Didymaios 27; Drymaios 78; Erethymios 40; Klarios 61. 116; Lairbenos 41; Pandemos 151: Pythaios 81; Pythios 111; Samnaios 69. Ares: 13. Artemis: 10. 35. 44. 59. 68-69. 84. 152. 158. 162. 173; Agrotera 67. 158; Bloureitis 67; Brauronia 48; Ephesia 27; Gazoreitis 67; Leukophryene 85; Pergaia 69. Asklepios: 18. 47. 59-60. 68. 84. 96. 109-111. 114-115. 132. 134. 189-190. Athena: 3 45. 84. 91. 96. 104-105. 121. 185. 188; Alea 24; Areia 185; Azesie 156; Chitone 46; Leitis 56; Lindia 40. 80; Polias 58. 119; Skyletria 56; Syleteira 56. Brimo: 7. Demeter: 27. 72. 83-84. 90. 103. 110. 112. 132. 143. 158; Potnia 90. Dionysos: 8. 10. 20. 28. 68. 72. 84. 96. 115. 117. 124. 173; Bakcheus 8; Dasyllios 8; Narthakophoros 69; Patroos 8; Thyllophoros 182. Dioskouroi: 44. 131. Dodekatheon 18. 99. Eileithyia: 130. 157-158. Ennodia: 35. Ge: 6. 112. 185. Hekate: 61. 71. 149; Aoria 72; Laginitis 76. Helios: 40. 71. 134. 185; Pantepoptes 169; see also Zeus. Hephaistos: 45. Hera: 38. 45. 135; Argeia 4; Zygia 58. Herakles: 16.66. 154; Agoraios 54; Kynagidas 68; Patroios 68. Hermes: 45. 66. 84. 91. 96. 143. 154; Agoraios 95; Chthonios 7; Enagonios 182; Propylaios 162. Hestia: 40. Homonoia: 84. Hosios kai Dikaios: 167. 170. Hygieia: 59-60. 84. 109. 111 190. Iaso: 104. Iatros: 104. Kabeiroi/Kab(e)iros: 72. 83. 110. Kore: 110.112 143. 158. Korybantes: 72. 84. Kronos: 20. Leto: 140. 153. Meter: 31. 53. 158, Andeirene 142; Megale 96; Patroia 31; Theon 68. 170. Methysis: 104. Moirai: 26. Nemesis: 84. 99. 134. Nike: 84. 91. 99. Nymphs: 115. 183. Nyx: 20. Ouranos: 20. Pan: 84. Parthenos: 91. Persephone: 72. Plouton: 72. Ploutos: 29. Poseidon: 24. 72. 118. 138. 183. 185; Hippios 40. Protogonos: 20. Rhome: 23. 66. 159. 172. Tauropolos: 185. Telesphoros: 59. Theoi: 153; Chthonioi 153; Epidaurioi: 114; Megaloi 72. 83. 135. 190; Pantes 28. 130; Patrioi 116.172. 
Theos: Hypsistos 51. 116; Megas 124. Trophonios: 110. Tyche: 60. 84. Zeus: 6. 13. 20. 45. 52. 68. 72. 84. 86. 96. 102. 153-154. 159. 185; Akraios 22; Areios 86; Atabyrios 69; Barachos 50; Chrysaoreus 149; Helios 139; Hypsistos 125. 139; Kapetolios 176; Kannokos 176; Karaios 188; Kretagenes 178; Kronion 139?; Labraundos 185; Megas 139; Megistos 116; Meilichios 158; Nemeios 4. 114; Olympios 22. 58. 166; Opores 112; Ouranios 139; Panamaros 57. 176; Polieus 80; Sarapis 122. 139; Sosonianos 13; Soter 130. 188; Teleios 40; see also personifications

deities, Anatolian: Kakasbos: 61; Kybele: 84; Men/Mes: 99. 142. Egyptian: 43. 84. 92. 110. 122. 126. 139. 144. 173. Oriental: Agdistis: 17; Atargatis: 11; Manes: 71; Mithras: 71. 96; Sabazios: 64; Thea Syria: 11; Zeus Tour Barachos: 50. Roman: Iuno: 173; Iupiter: 173; Iupiter Optimus Maximus: 125; Capitoline Triad: 45.58 96; Liber Pater: 173; Silvanus: 96. 173. Thracian: Derzelas: 124; Melsa: 84; Rider God: 5. 59. 96. 173

deities, descent from: 6; patrons of agriculture: 65; of city: 27-28; of healing: 104. 110. 115. 139, of prostitution: 151; of seafaring: 151; of youth; 111; of war: 56

Derveni papyrus: 6.20

divination: 71. 115. 150; see also cult personnel (prophetes), oracle dream: 143

earth: 6

Eleusis, Eleusinian mysteries: 27. 29. 72. 83

emperor cult: 13. 22. 45. 58. 70. 79. 159. 168-169. 173. 177. 188-189

epiphany: 39

eschatology: 6

expiatory ritual: 150

festival: 25. 39. 91. 118. 137. 153. 163-165; commemorative: 187; distributions during f: 91; dramatic contests: 184

festivals: Adonia: 42; Asklepieia, Megala: 18 (Kos); Compitalia: 66 (Delos); Dionysia: 10. 98 (Athens). 18 (Kos). 42 (Methymna); Dionysia xenika: 8 (Kallatis); Hadriana Olympia: 166 (Ephesos); Hadrianeia: 22 (Ephesos); Hadrianeia Olympia: 22 (Kyzikos, Smyrna); Hadrianeios Philadelphios: 164; Haloa: 42 (Athens); Heraia: 42 (Olympia); Koina Asias: 70 (Smyrna); Komyria: 57 (Stratonikeia); Nikephoria: 119 (Pergamon); Olympia: 22 (Ephesos, Kyzikos, Smyrna). 42 and 163 (Olympia); Panathenaia: 3 (Athens). 121 (Ilion). 155 (Athens); Skira: 42 (Athens); Stenia: 42 (Athens); Thesmophoria: 42

finances, of cults/sanctuaries: 8. 33. 80. 119. 182

fire: 6

funerary cult: 5-7. 19. 88. 115-116. 166; imprecation: 153. 170

gem: 36.60

grove: 118

gymnasium: 16

hair, dedication of: 57.111

healing, healing deity: 104. 110. 115. 139

hero cult: 24 (Palaimon). 30 (Achilleus). 35 (Aspalis). 48 (Iphigeneia). 59 (Thracian Rider). 61.74 (Aiatos). 84 (Melsa, Sosipolis). 148 (Achilleus). 150 (Agamemnon, Kassandra)

heroisation: 6-7 
Homer: 49

hymn: 27. 123. 134. 178; hymnodos: 58. 70. 160

immortality: 71

incubation: 97. 110

initiation: 6. 68. 71.83

inventory: 89. 136

justice, divine: 41. 99. 141-142

lamp: 51.139

land, sacred: 69. 73. 136. 141. 145-146. 190

lex sacra; see cult regulation

libation: 15.18

light: 83

magic: 26. 36. 60. 87. 120; see also amulet, curse

miracle: 57 ; see also epiphany

Mithraic mysteries: 71

monotheistic tendencies: 116

music, musicians: 34. 134. 163

Mycenaeans: 74. 112

mystery cult: 6-8, 18. 68. 71. 83. 107, 158 (Agrai). 160; see also Eleusis, Orphics

mythology: 1. 37.52 (Kassandra). 74 (Aiatos); see also hero

names, theophoric: 31. 43.186

neokoria: 22

nymph(s): 78. 115. 183

oath: 28. 185

oracle: $38.85 .115-116.123 .148 .165$

Orpheus: 154

Orphics, Orphism: 6-7. 68. 71. 123. 174

paganism in Late Antiquity: 161

peplos: 3

personifications: 84; Methysis: 104; Pistis: 66

pilgrimage: 101

Phoenicians: 11

politics and religion: 34. 46. 55. 93. 108. 118. 150

prayer: 123

priesthood, priest: 40. 115. 119. 141, 153; board of: 40; career of: 40; clothes of: 115; contribution to festival: 153; dedications of: 76 ; for life: 13. 24 . 40. 176; former p.: 40. 125; identity of: 40; iteration: 23 ; purchase of: 152.182

procession: 27.37 .158

proskynema: 82

punishment, divine: 142

purity, purification: 39. 115. 158; of the mind: 115.161 
rite of passage: 133.180

ritual, dynamics: 27; introduction of: 57. 111; organisation of: 27; see arkteia, banquet, expiatory r., incubation, initiation, libation, oath, procession, sacrifice, supplication, theoxenia

royal cult: 18 (Alexander, Ptolemy)

sacrifice: 15. 47. 66. 69. 97. 113. 115. 129. 153. 182-183. 185; sacrificial animal: 73. 128 (yearling). 153 (ox). 185 (bull, boar)

sacrilege: 53.56

sanctuary: $8.34 .41 .89 .108 .118 .136 .141 .145-146$; building activities: 113. 136; fines paid to s.: 152-153; privileges of: 175; publication of documents in: 94; revenues: 119. 136. 141. 185; rural: 41. 141; supra-regional: 181; see also asylia, finances, inventory, land, thesauros

sexuality: 133.151

slave, of god: 141

soul: 6

statue, cult: 125

supplication: 63

Syrians: 11

theogony: 19

theoria: 18; theorodokos: 4.108 ; theoros: 18. 135. 180; architheoros: 184

theosophy: 116

theoxenia: 150

thesauros: 110

vow: 43. 167; see Greek words (Eư $\left.\chi_{1}^{\prime}\right)$

war: 56.86

water: 190

wine: 104.115

women: 42. 138. 150

wreath: 8

\section{Greek Words}

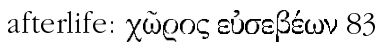

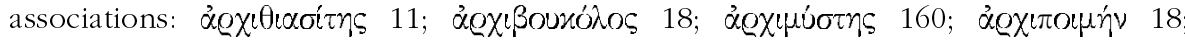

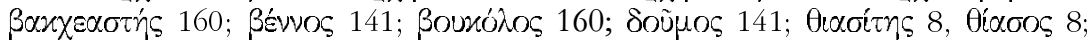

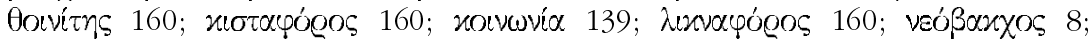

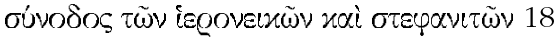

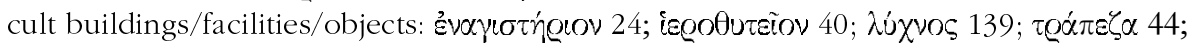

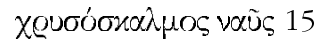

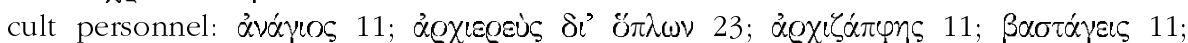

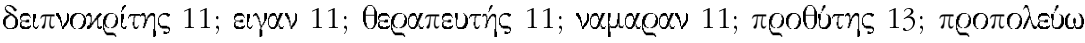

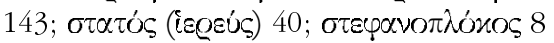

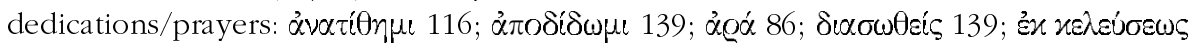

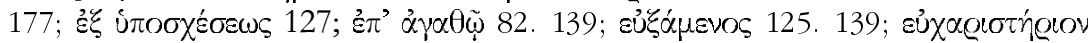

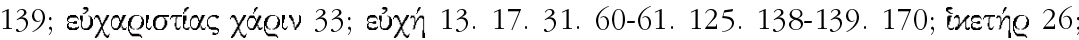

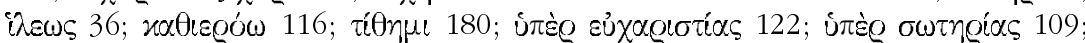

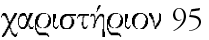




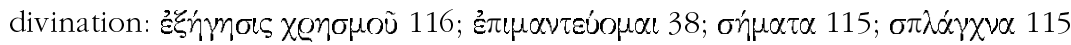

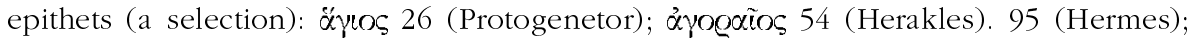

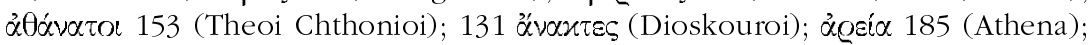

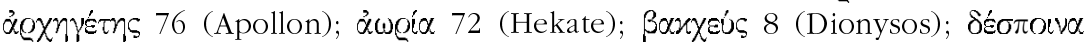

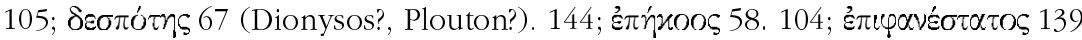

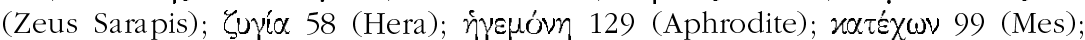

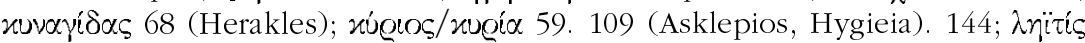

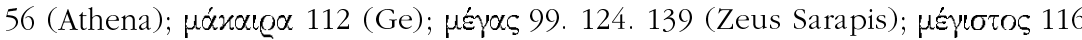

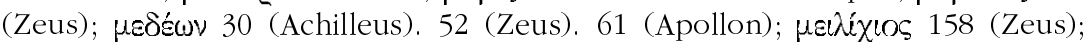

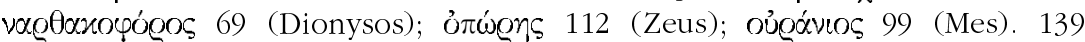

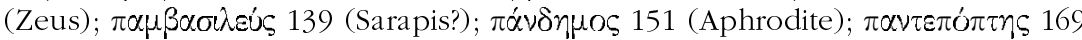

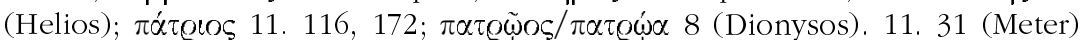

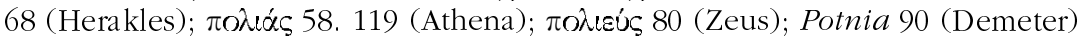

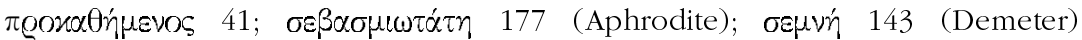

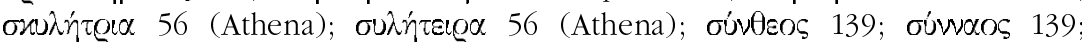

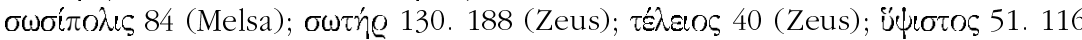

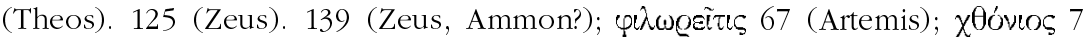
(Hermes). 153 (Theoi)

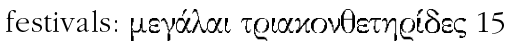

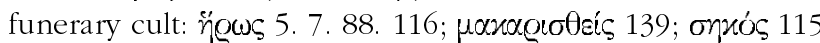

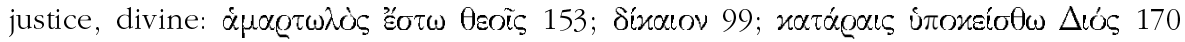

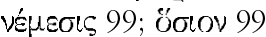

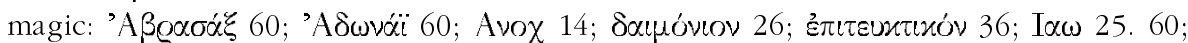

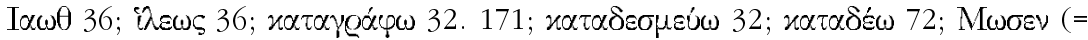

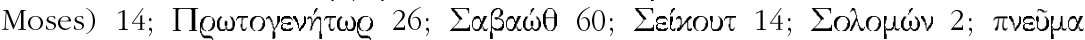

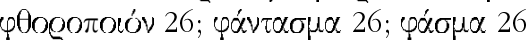

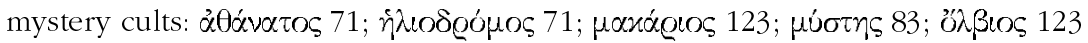

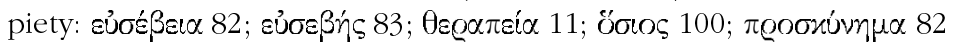

rituals: $\pi \varrho 0 \sigma \tau 00 \pi \dot{\alpha} 150$

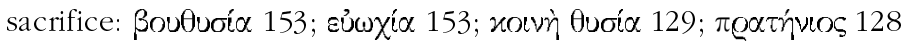

1) C. Abadie-Reynal, "Les maisons aux décors mosaïqués de Zeugma", CRAI (2002), p. 743-771 [cf. BE 2002, 72]: Overview of the mosaic that decorated private houses in Seleukeia/Zeugma (Roman Imperial period). Some of them are inspired by mythology (the wedding of Dionysos and Ariadne, Daidalos and Ikaros, Achilleus in Skyros, Poseidon, Tethys and Okeanos, Andromeda and Perseus); the mythical figures are identified with inscriptions (Pasiphae, Daidalos and Ikaros, Dionysos, Nike and Bakche, Andromeda, Perseus, xútoc). [AC]

2) S. Agady et al., "Byzantine Shops in the Street of the Monuments at Bet Shean (Scythopolis)", in L.V. RuTGERs (ed.), What Athens has to do with Jerusalem. Essays on Classical, Jewish, and Early Christian Art and Archaeology in Honor of Gideon Foerster, Leuven, 2002, p. 423-506 [SEG LII 1684-1685]: Ed. pr. of two amulets (Skythopolis, Late Antiquity; 3 and 5). The first amulet is a circular clay medallion with the inscription $\Sigma 0 \lambda o u(o v v$ and an unidentifiable object (perhaps the root of the mandragora plant by which Solomon controlled the demons). The second amulet is made of black steatite and set in a silver frame; on the obverse a schematic snake-legged figure (Abrasax), on the reverse the imperative $\pi \dot{\varepsilon} \pi \tau \varepsilon$ ('digest!'); the amulet was used against stomach diseases. [AC]

3) S.B. Aleshire - S.D. LAmberT, "Making the Peplos for Athena: a New Edition of IG $\mathrm{II}^{2}$ 1060 + IG II' 1036", ZPE 142 (2003), p. 65-86 [BE 2004, 165]: L. presents, on the basis of 
autopsies made by A. before her death and by himself, a new edition of a very fragmentary Athenian inscription ( $I G \mathrm{II}^{2} 1060+1036,108 / 7 \mathrm{BC}$ ) which preserves two decrees concerning the peplos of Athena and the Panathenaic procession. The first decree contains general regulations; the second honors the partheno $i$ who had made the peplos presented to the goddess in that specific year. Already the earlier editors identified the partheno $i$ with the ergastinai responsible for the weaving of the peplos. In a useful appendix L. discusses briefly prosopographical aspects of the list of the maidens, which is organised according to the tribes. The large majority of the maidens belonged apparently to families which held similar religious and secular offices, although only one of them was member of a family with a prominent position already in the Classical period (the family of Kallias from Bathe, fr. b, 1. 43). The text shows that maidens were allowed to work on the peplos more than one year, since four of the parthenoi of the tribe Akamantis in the list of 108/7 reappear in a list of $103 / 2\left(I G \mathrm{II}^{2} 1034+1943\right)$, and two from the latter list reappear in the one of c. 100 ( $I G \mathrm{II}^{2}$ 1942). [JM]

4) A. Alonso Déniz - M.L. Del Barrio Vega, "À propos de la stèle de Pallantion, SEG XI 1084”, ZPE 144 (2003), p. 141-146: The authors offer some minor corrections to a document concerning the renewal of the friendly relations between Argos and Pallantion (Pallantion, 3rd cent.; SEG XI 1084). In lines 29-31 there is a reference to the theorodokoi of Zeus of Nemea and Hera Argeia (lines 29-31). [JM]

5) D.G. AngeLov, "New Greek Inscriptions from the Strymon Valley (Province of Macedonia)", ZPE 143 (2003), p. 138-142: Ed. pr. of a funerary relief for a Roman rider (2; near Sandanski; Imperial period); the deceased man is called a $\ddot{\gamma}$ ow . The relief adapts the iconography of the Thracian Rider, showing in the upper register a rider, a small person on the left, and a snake twined around a tree on the right. In the lower register two women are depicted in a mourning gesture, accompanied by a third woman [see also EBGR 2002, 33]. [JM]

6) A. Avagianou, "Physiology and Mysticism at Pherai. The Funerary Epigram for Lykophron", Kernos 15 (2002), p. 75-89 [SEG LII 567]: A. republishes with English translation the interesting funerary epigram for Lykophron from Pherai in Thessaly (SEG XXVIII 528, 3rd cent.): "I, Lykophron, the son of Philiskos, seem sprung from the root of great Zeus, but in truth am from the immortal fire; and I live among the heavenly stars, uplifted by my father; but the body born of my mother occupies mother-earth". A.'s detailed analysis of the eschatological ideas expressed in this epigram show that Lykophron was probably a heroised initiate in the 'OrphicDionysiac' mysteries, which are attested in Pherai (SEG XLV 646; EBGR 1996, 40). A. observes that

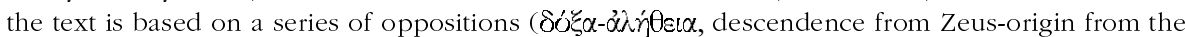
cosmic fire, soul-body, heavenly stars-earth, father Zeus-mother Earth), close parallels for which can be found in Presocratic writings, in the Derveni papyrus, and in Orphic texts. The opposition truth-lie and body-soul, e.g., is attested in the Olbian bone tablets (IGDOP 74; EBGR 1987, 32; 1991, 264; 1992, 245; 1996, 62; 1997, 343; 1999, 242; 2000, 119 and 198); the expression urire $r$ r recalls the phrase $\Gamma \tilde{r} \zeta \pi x i \varsigma$ si $i_{!}$in Orphic texts. The poem's main idea is that the soul is immortal fire associated with Zeus-Father and cognate with the stars. [AC]

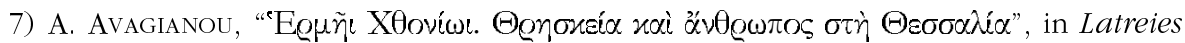
p. 65-111 [SEG LII 546]: A. studies in great detail the funerary stelae dedicated to Hermes Chthonios in Thessaly (primarily in Pelasgiotis). She distinguishes four subgroups according to the formulas used and their decoration with engraved representations of the god. The form of the stelae (naiskos stelae), the dedicatory formula 'to/of Hermes Chthonios', and the significance of Hermes Chthonios in Greek concepts of afterlife and in Greek magic lead A. to the assumption that in Thessalian popular religion the deceased person - often designated with the attribute rows - was heroised and identified with Hermes Chthonios. A connection with the 'Orphic-Dionysiac' mysteries is probable, since Hermes was associated with Brimo, who is mentioned in one of the Thessalian 'Orphic' texts (SEG XLV 646; EBGR 1996, 40). Hermes possibly played a role in ancient mystery cults (e.g., IG XII.1, 141; XII.8, 70). [AC] 
8) A. Avram, "Der dionysische thiasos in Kallatis: Organisation, Repräsentation, Funktion”, in U. EgelHAAF-GAiser - A. SCHÄFER (eds), Religiöse Vereine in der römischen Antike, Tübingen, 2002, p. 69-80 [BE 2003, 389]: A. gives an overview of the cult of Dionysios in Kallatis, which is attested epigraphically as one of the most important cults of this city (4th cent. BC - 1st cent. AD); Dionysos was worshipped with the epithets Bakcheus, Dasyllios, and Patroos. A. discusses in detail the organisation of the Dionysiac association

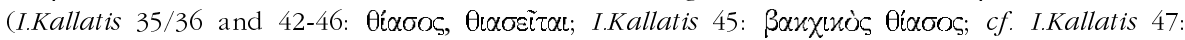

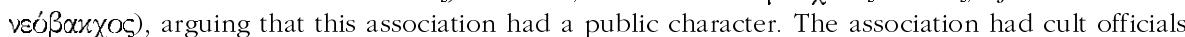

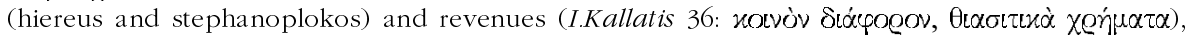

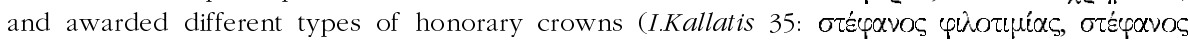
$\dot{\alpha} \pi \circ \delta c \chi \tilde{\alpha} c)$ depending on the contribution of the members [on different types of crowns, such as

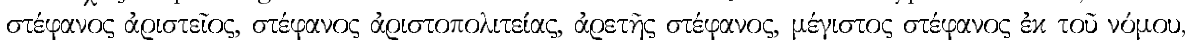
see A. CHANIOTIS, "Griechische Rituale der Statusänderung und ihre Dynamik", in M. STEINICKE S. WEINFURTER (eds), Investitur- und Krönungsritual, Cologne/Weimar, 2005, p. 56]. The Dionysiac

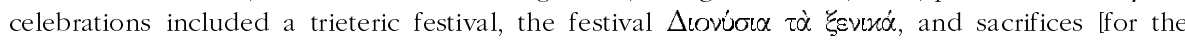
expression $\pi \varrho x \tau \dot{r} v i c \subseteq$ in the context of a sacrifice in I.Kallatis 47 see infra, $\mathrm{n}^{\circ} 128$ ]. A. suspects that celebrations that took place in the theater were not reserved for the mysts alone. [IGBulg $\mathrm{I}^{2}$ 12 (p. 75 note 29) seems to me irrelevant for a distinction between mysts and other citizens in the cult practice; the text simply states that a priest performed sacrifices "on behalf of the mysts and the polis"]. The cult of Dionysos took place in various cult facilities, including the sanctuary called

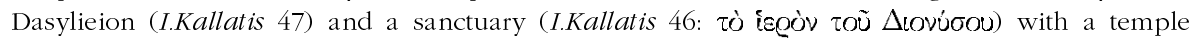

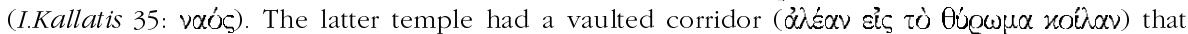
lead to (subterranean?) vaulted chambers ( $\psi \alpha \lambda i \delta \varepsilon c)$ ), probably imitating caves ( $c f$. I.Kallatis 44:

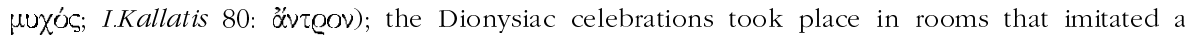
mythical landscape [for the reproduction of mythical or real landscapes in cult see A. CHANIOTIS, "Ritual Dynamics in the Eastern Mediterranean Case Studies in Ancient Greece and Asia Minor", in W.V. HARRIS (ed.), Rethinking the Mediterranean, Oxford, 2005, p. 161]. [AC]

9) A. Avram, "Zu zwei Inschriften aus Agathopolis", in Jubilaeus V, p. 17-19 [SEG LII 658-659; $B E$ 2003, 386]: A. republishes two honorary decrees found in Agathopolis (c. 320-250; originally published by V. VelKov, Thracia Pontica 5, 1994, p. 105-112; non vidimus), demonstrating that these decrees were in fact passed by Apollonia Pontica. There is no evidence that the fortress at Agathopolis had the status of a polis. The decrees were to be set up in the sanctuary of Apollon in Apollonia (cf. IGBulg I $391=$ SEG LII 661). [The first decree attests the office of the

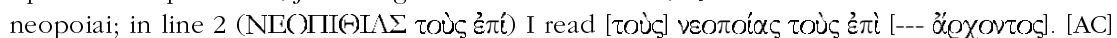

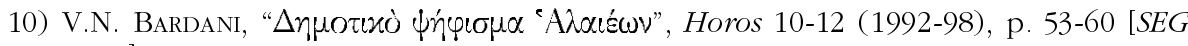
XIVI 153]: Ed. pr. of a decree of the demos of the Halaieis in honor of two choregoi, found near the temple of Artemis (Halai Araphenides, $341 \mathrm{BC}$ ). The fact that the stele was to be erected in

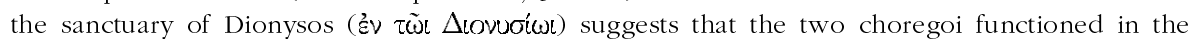
rural Dionysia in this deme. $[\mathrm{AC}]$

11) M.-F. BASLEz, "Entre traditions nationales et intégration : les associations sémitiques du monde grec", in Influenze vicino-orientali, p. 235-247 [SEG LII 1898]: B. gives an excellent overview of the private associations - including the cult associations - founded by persons of Semitic origin (Phoenicians, Syrians, Cypriots) in Greece, exploiting the evidence of numerous inscriptions, especially from Athens and Delos. These associations usually preserved

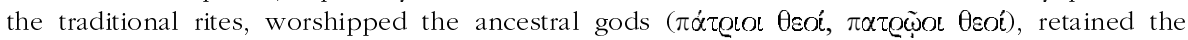
designations of cult officials and cult objects associated with traditional rituals (e.g., jंvófycoc,

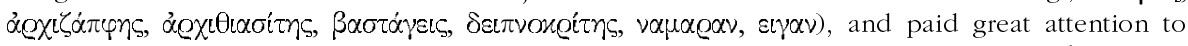
ritual banquets. Also the idea that an association was founded by a divinity (SEG LII 761) was of Semitic origin. In the case of the Syrian associations, which had a more durable organisation, one observes an amalgamation of Syrian and Greek traditions in the cult of Thea Syria/Atargatis. The members of the associations participated in the public festivals of the cities where they resided. An influence of the Semitic associations on Greek religious practices may be recognised in the figure of the therapeutes and the concept of therapeia as a religious service. [AC] 
12) A.J. BAYliss, "Curse-Tablets as Evidence: Identifying the Elusive 'Peiraikoi Soldiers", ZPE 144 (2003), p. 125-140 [BE 2004, 150]: B. shows convincingly that P.Oxy. 2082, DTA 55 (SEG XXXVII 215, late 4th cent.), and a dedicatory inscription from Piraeus ( $I G \mathrm{II}^{2} 1954$, late 4th cent.) refer to the same group of people, soldiers stationed in the harbour city of Athens

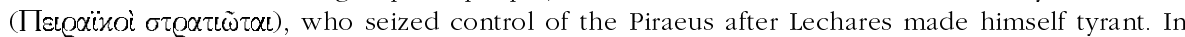
at least one case there is even an exact correlation between the defixio and the dedicatory inscription: Oineides, son of Apollodoros, of Eroiadai appears in both texts: DTA 55, lines 9-11 and $I G \mathrm{II}^{2} 1954$ line 10. [JM]

13) R. BehrWald, "Inscriptions from Pednelissus", AS 53 (2003), p. 117-130: During an epigraphic campaign in Pednelissos (Pisidia) in 2000, B. revised 21 inscriptions and discovered 5 new texts (marked with an asterisk). The most interesting text is a dedication made to Hadrian and the Demos by the priest of Zeus and prothytes of the emperor cult, after his term of office; the dedication consisted of an inscription and 200 denarii $(5=S E G$ II 718); the interest of the text

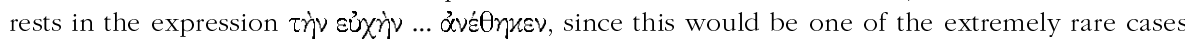
of a vow addressed to an emperor. [But $\tau \dot{\gamma} v \varepsilon \dot{x} \chi \dot{\eta} v$ may be used as a synonym of $̇ \pi \alpha \gamma \gamma \varepsilon \lambda \dot{\alpha} \alpha$, i.e., the promise made by the priest upon assuming his office; see A. CHANIOTIS, "Der Kaiserkult im Osten des Römischen Reiches im Kontext der zeitgenössischen Ritualpraxis", in H. CANCIK - K. Hitzl (eds), Die Praxis der Herrscherverehrung in Rom und seinen Provinzen, Akten der Tagung in Blaubeuren vom 4. bis zum 6. April 2002, Tübingen, 2003, p. 19f.; for such summa honoraria

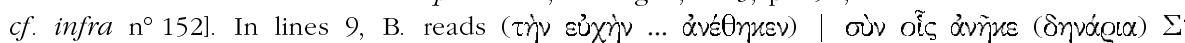
("according to his vow dedicated this, together with 200 denarii to which it belongs"), instead of oùv yuvaxí [rather: "dedicated this vow"; what the priest dedicated is probably not the inscription, but an object or building standing next to the inscription]. A father and his son, designated as

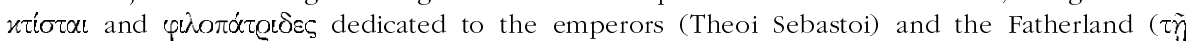
$\gamma[\lambda u] x u \tau \dot{\alpha} \tau \gamma, \pi \alpha \tau \in \dot{\delta} \delta l)$ a temple (obviously for the emperor cult) and its pronaos with all their decoration ( $3=S E G$ II 724 , 2nd cent. AD). The object of another dedication to Antoninus Pius

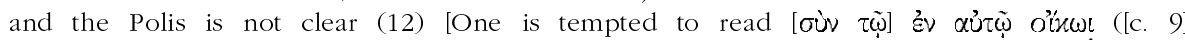
FN MYTQOIKSI, B.), but on the (not very clear photo) I read $\sum$ YNTEN $\Lambda$ YTSOIKQ]. A priest of Ares for life contributed during his term as high priest to the construction of an arena

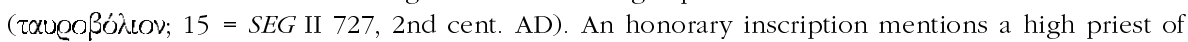
the civic emperor cult $(8 \mathrm{~d}=S E G$ II 714). A local benefactor bequeathed 215 denarii to Zeus Sosonianos $\left(9=S E G\right.$ II 719 , 3rd cent. AD). A fragmentary text refers to panegyriarchoi $\left(11^{*}\right.$, 2nd.

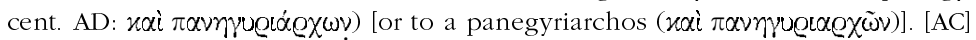

14) A. BeTORI, Quaderni della Soprintendenza Archeologica del Piemonte 19 (2002), p. 59-66 [SEG LII 949; non vidimus; cf. B. PuECH, An.Ép. (2002) [2005] n 484]: Ed. pr. of a gold leaf/amulet (Forum Fulvii, Imperial period) inscribed with a magical text aiming at protecting the owner from headache. The text consists of logoi inspired by Egyptian words and

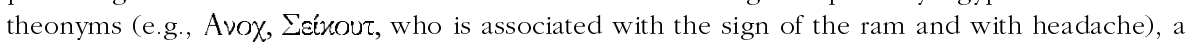

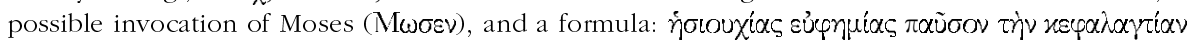

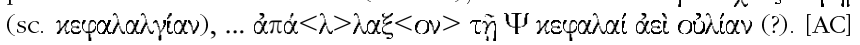

15) J. Bingen, "Le décret sacerdotal de Karnak (142 a.C.)", CE 77 (2002), p. 295-302 [SEG LII 1805; BE 2003, 631]: B. republishes four fragments of a decree of priests from Karnak in honor of Ptolemy VIII and Kleopatra II (142 BC; SB 4542), suggesting a new arrangement of the fragments, new restorations and interpretations, and a historical context (the visit of the royal couple in $142 \mathrm{BC}$ ). The decree refers to sacrifices and libations (B 2) and to a ship used in

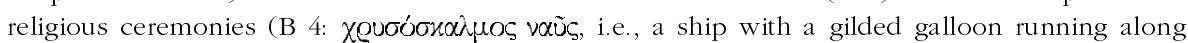
the row of tholes) and summarises the benefactions of the kings (C+D 31-46), who inter alia

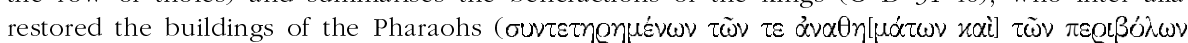

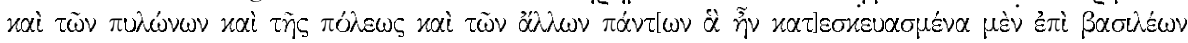

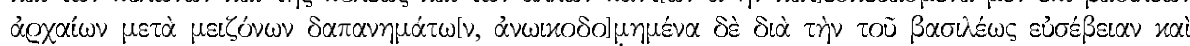

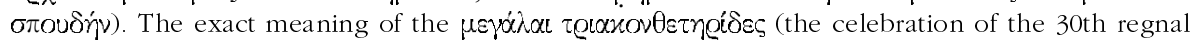
year of Ptolemy VIII?, anniversary of a regnal year?, a sacred cycle?) is not clear. [AC] 
16) J. Bingen, "SEG XLVII 1866: Cléopâtre et Chypre", CE 78 (2003), p. 236-240: B republishes a dedication made by a lampadarches to Herakles in a gymnasium in Amathous ( $S E G$ XLVII 1866) [EBGR 1997, 196], determining the date (36/35 BC) and discussing the titulature of

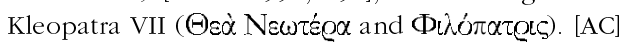

17) Bonhams \& Brooks, Antiquities. Thursday 8 November 2001, London, 2001 [SEG LI 2220]: Ed. pr. of a gray marble statuette of an enthroned goddess (p. $40 \mathrm{n}^{\circ} 121$, Phrygia?, 2nd/3rd

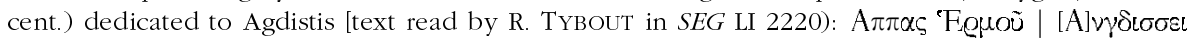
sủxón| v. [AC]

18) D. Bosnakis - K. Hallof, "Alte und neue Inschriften aus Kos I", Chiron 33 (2003), p. 203-262 [BE 2004, 211, 225, 237-238]: The edition of 19 new or rediscovered inscriptions from Kos includes several texts of religious interest. Several texts mention the dedication of the inscription in the sanctuary of Asklepios (2A, 4-6, 8-9). Common honors are the crowing of the honorands, to be announced under the responsibility of the agonothetes during the Dionysia (2A, $4-5,8-9)$. The crowing of a Sikyonian honored by the Koans ( $2 \mathrm{~A}, 2$ nd cent.) was to be announced during the next contest of the Dionysia directly after the libations and during the next contest of the Great Asklepieia ( $c f .8-9$ ). In an unknown Ionian city Koan judges were honored during the Dionysia, on the first day of the competition of the flutists under the responsibility of the agonothetai of the music contest ( 7 , late 2nd cent.). The Samothrakians honored Praximenes from Kos (4, c. 250-200), who was sent to Samothrake as Koan theoros (line 12, to the mysteria?). A building inscription records building activities in the cixos of the association of the winners at the

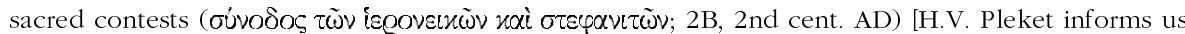
per ep. that the synodos is one of Dionysian technitai, i.e., the special group of sacred-crown

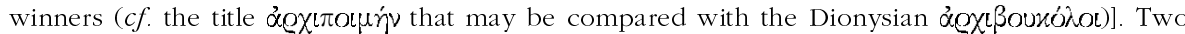
honorary decrees for unknown persons $(12,3 \mathrm{rd}$ cent.) were to be erected in the sanctuary of the Twelve Gods. A fragmentary decree (13, c. 250 BC) refers to sacred precincts for Alexander and

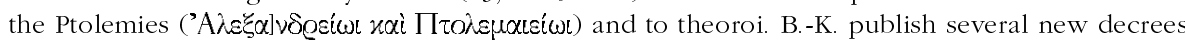
of cities (Gonnoi, Homolion, Phthiotic Thebes, Megara, Thessalian cities, unknown cities) and a letter of Ptolemy III recognizing the asylia of the Koan Asklepieion (14-19). [JM]

19) B. Boyaval, "Notes d'épigraphie funéraire. I", CE 78 (2003), p. 248-250 [BE 2004 , 407 and 413]: B. republishes and discusses a passage of a funerary epigram for a woman from Pisidia, buried in Memphis (BerNAND, Inscr. métr. 32), near her pious father, improving the translation: "Toutefois, s'il est vrai que les tombes de ta patrie ne te renferment pas, toi la Pisidienne (car Memphis, consacré à Danaos, t’a cachée dans sa poussière), du moins tu habites avec les hommes pieux et tu partages la même demeure que ton père Diogène." [AC]

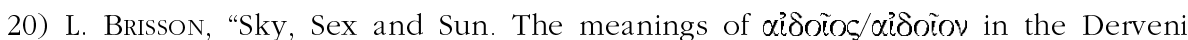
papyrus", ZPE 144 (2003), p. 19-29: According to B. the Derveni papyrus seems to be mainly a commentary on the Orphic rhapsodies, apart from the divine figure of Chronos (Time), which does not appear in the papyrus. The traditional succession can be found in the papyrus: Night, Protogonos, Ouranos, Kronos, Zeus, and Dionysos. The commentator is apparently playing with

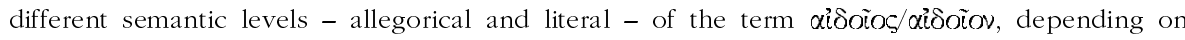
whether it is used as a masculine or a neuter. As an adjective $\alpha i \delta c i o c$ can characterise a divinity, according to B. the luminous Protogonos (col. XIII and XVI). Aisoiov designates literally the penis of Ouranos, and metaphorically the sun, i.e., the transformed penis of Ouranos after its amputation by Kronos. The designation of Kronos as aionoios should then in this context characterise him as the one who castrated. By swallowing Protogonos Zeus (the cooling effect of the air) swallows at the same time a penis/sun as the origin of everything. B. concludes that the commentator is apparently singing a hymn to the sun, since Protogonos is in a way the sun, Ouranos has originally the sun/penis as a part of him, which after the castration becomes literally the sun. Finally, Zeus, as the cooling effect of the air and the one who swallowed Protogonos/penis/sun, is the ultimate instrument of generation, the sun. [JM]

21) P. BRUNEAU - P. Fraisse, Le monument à abside et la question de l'autel de cornes Athens/Paris, 2002 [SEG LII 758; BE 2003, 102]: The Delian 'altar of horns' (Kegatív) 
mentioned in the Delian accounts should be identified with an apsidal monument (Guide de Délos n 39; p. 59-79). B.-F. present a detailed architectural study of this monument. [AC]

22) B. Burrell, "Temples of Hadrian, not Zeus", GRBS 43 (2002/2003), p. 31-50: B. argues that the assumption that Hadrian was worshipped in his temples in Kyzikos ( $c f$. IGR IV 140), Smyrna (cf. I.Smyrna 595 and 697), and Ephesos as Zeus Olympios or together with Zeus Olympios is unfounded. The neokoria was awarded to Kyzikos in AD 123 or 124, i.e., before Hadrian received the epithet Olympios in Athens (AD 128). The same applies to Smyrna (neokoria in $124 \mathrm{AD}$ ), where Hadrian's temple should be distinguished from that of Zeus Akraios. The Ephesian neokoria was awarded by Hadrian in AD 132 ( $c f$. IG II $^{2}$ 3297), but there is no reference to Hadrian Olympios or Zeus Olympios in the evidence for his cult (cf. I.Ephesos 279, 428, 742, 814, 921), and the cult of Zeus Olympios in Ephesos predates Hadrian. The epithet Olympia in the name of the agon for Hadrian in Kyzikos (Hadrianeia Olympia, Olympia) does not prove that Hadrian shared a temple with Zeus Olympios in this city; the attribute Olympia refers to Hadrian's own epithet. In Smyrna and Ephesos, where Olympic festivals (Olympia) already existed, the new agons for Hadrian were distinguished from them and were called Hadrianeia or Hadrianeia Olympia (Smyrna) and Hadrianeia (Ephesos), never simply Olympia [ $c f$. infra $\left.\mathrm{n}^{\circ} 70\right] .[\mathrm{AC}]$

23) H. Buyukliev - N. Sharenkov, "Novootkrit epigrafski pametnik za stritelnata deinost i obstestvenija zivot v Avgusta Trajana pri Severite", in Jubilaeus V 82-93 (in Bulgarian) [SEG LII 694]: Ed. pr. of an honorary inscription for the benefactor M. Aurelius Asiaticus (Augusta Traiana, early 3rd cent. AD), who had served in many offices including those of the

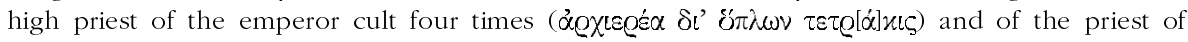
Rome (izQźa 'Póurs). [AC]

24) F. CAmia, "IG IV 203: La cronologia di P. Licinius Priscus Iuventianus, archiereus della lega Achea", ASAA 80 (2002), p. 361-378 [BE 2004, 38]: The high priest of Achaia P. Licinius Priscus Iuventianus is known through an inscription that records his building activity in the sanctuary of Poseidon at the Isthmus (IG IV 203; $c f$. EBGR 1989, 39) and through several other fragmentary inscriptions (Corinth VIII.3, 199-201; SEG XXVI 410 = XLIV 309; XXXIX 340). From this evidence one should exclude an inscribed statue of Poseidon (IG IV 202) which mentions the priest P. Licinius Priscus; this person was probably a sculptor from Aphrodisias (p. 363). The date of Iuventianus' building activity in the sanctuary and in particular in the Palaimonion, has been disputed in recent research (late 1st-late 2nd cent. AD). After a detailed analysis of the various phases of the construction of the Palaimonion and taking into consideration the dates of other high priests of Achaia for life (Cn. Cornelius Pulcher under Hadrian, Tib. Claudius Saithidas Caelianus and Tib. Claudius Polykrates under Antoninus Pius) and the use of the title Helladarches by the high priests after c. AD 125-128 and until the late 2nd cent ( $c f$. IG IV 590) C. dates Iuventianus' priesthood to the period before Hadrian and argues that the temple of Palaimon (the

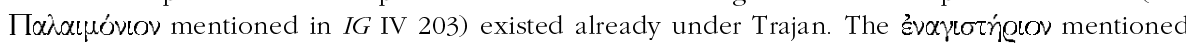
in IG IV 203 among Iuventianus' constructions may be identified with the eschara B. [C.'s arguments should be taken seriously under consideration in future studies concerning the Palaimonion, but there is a series of problems with his analysis. In addition to the fact that the letter forms of the relevant inscriptions favour a date in the late 2 nd and not the late 1st cent. AD, the wording of $I G$ IV 203 implies that Iuventianus was not responsible for the construction of the monopteros of Palaimon. The author of the text seems to make a distinction between temples

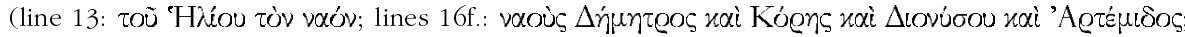

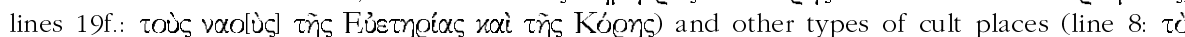

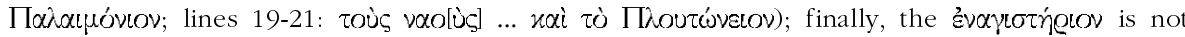

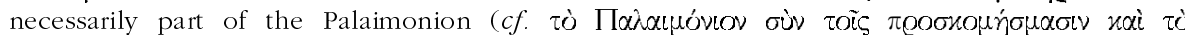
Evay see now the thorough discussion by J. MYLONOPOULOS in infra $n^{\circ}$ p. 174-182]. [AC]

25) A.C. CAssio, "Un epigramma votivo spartano per Atena Alea", RFIC 128 (2000), p. 129-134 [BE 2003, 328]: C. presents a new critical edition of a dedicatory epigram addressed

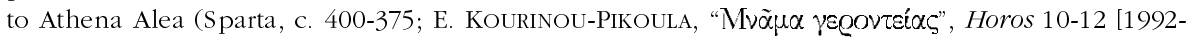


98], p. 259-276; cf. P. GaUTHIER, BE 1999, 241 and L. Dubois, BE 2000, 279) [SEG XLVI 400]:

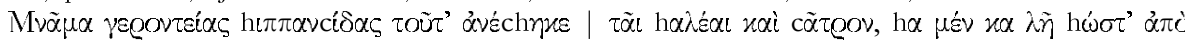

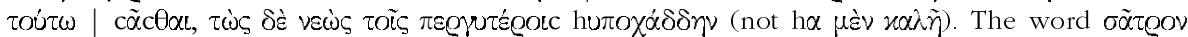
(sc. Ox̃ $\tau \varrho \circ v)$ designates a construction that allowed the observation of public festivals. ["Hippanthidas dedicated to Alea this monument and a satron in commemoration of his service as a member of the gerousia, so that anyone may watch whatever one may wish, under the condition that the young men give their place to the older men"]. [AC]

26) E. Cavada - G. PACI, "Un amuleto contro l'epilepsia dall'Alto Garda (Trentino sudoccidentale)", ArchClass 53 (2002), p. 221-256 [SEG LII 948; BE 2004, 76]: Ed. pr. of an inscribed silver leaf originally rolled up and placed into a silver case, found in a grave (Arco, Trentino, near Lago di Garda, 2nd/3rd cent.). The text begins with an invocation of "A

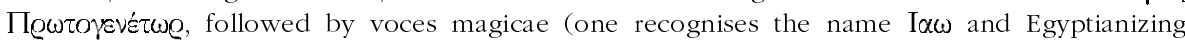
epithets; $c f$. PGM I Lines 204f.) and the long request of the owner of the amulet, Tertios, son of Sira (the Syrian?) to the sacred guardians to protect him in all circumstances from all kinds of dangers, fears, demons, ghosts, illnesses, and spirits, and in particular from the symptoms of

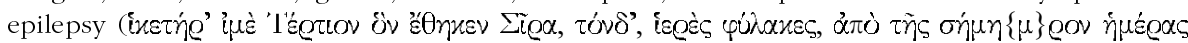

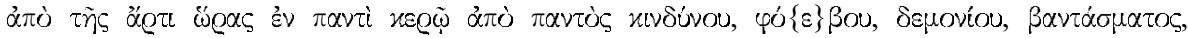

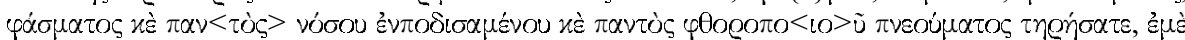

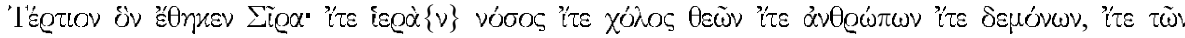

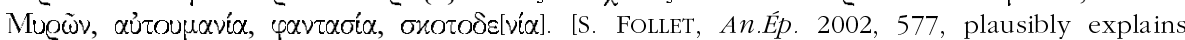

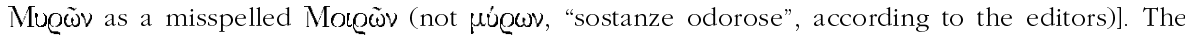

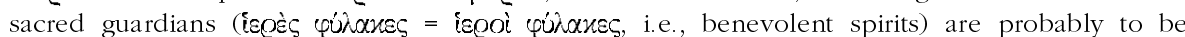
identified with the Sacred Procreator (not necessarily a reference to Christ) and Iao. The editors mention recently found amulets on gold leaves from Como (D. CAPORUSSO, "Como: i rinvenimenti archeologici di viale Varese", NAC 30 [2001], p. 229-233; A. MASTROCInQUE, "Una donna di Comum che credeva nella magia", NAC 30 [2001], p. 235-250), Aquileia and SammardenchiaPozzuolo (A. Giovannini, "Un pendente-amuleto del Museo Archaeologico Nazionale di Aquileia", Aquileia Nostra 72 [2001], p. 157-184). [AC]

27) A. Chaniotis, "Negotiating Religion in the Cities of the Eastern Roman Empire", Kernos 16 (2003), p. 177-190: Based on a detailed study of decrees regulating and organising religious activities initiated by members of the local elites in Athens (LSCG 8, c. AD 220), Ephesos (LSAM 31, c. AD 162-164), Miletos (LSAM 53, mid-1st cent. AD), and Stratonikeia (LSAM 69, late 2nd cent.), C. analyses the strategies of persuasion used by leading members of civic communities in the Imperial period in their dialogue with the community in cases such as celebrating religious banquets (Miletos), dedicating a whole month to the patron deity of a city (Ephesos), regulating the singing of hymns in the bouleuterion by young boys (Stratonikeia), or reorganising a procession according to the ancestral customs (Athens). The members of the elite seem to focus on gods with a privileged position in a city's pantheon (Artemis Ephesia, Apollon Didymaios, Demeter Eleusinia), to emphasise the material advantages of new or renewed festivals, and in almost all cases to refer to moral, educational, and religious values. C. also underscores the significance of individual religiosity in such initiatives. [For a German version, with a stronger focus on the notion of 'ritual dynamics' see $i d$., "Das Bankett des Damas und der Hymnos des Sosandros: Öffentlicher Diskurs über Rituale in den griechischen Städten der Kaiserzeit", in D. HARTH - G. SCHENK (eds), Ritualdynamik. Kulturübergreifende Studien zur Theorie und Geschichte rituellen Handelns, Heidelberg, 2004, p. 291-304]. [JM]

28) K. Clinton, "Maroneia and Rome: Two Decrees of Maroneia from Samothrace", Chiron 33 (2003), p. 379-417: Ed. pr. of two decrees of Maroneia, brought probably in Byzantine times to Samothrake. Both decrees were issued during the reign of Claudius and concern the dispatch of ambassadors to the emperor in order to persuade him to restore or maintain privileges having previously been granted to Maroneia by Rome. The first decree documents a successful embassy to the emperor. Lines $35 \mathrm{f}$. briefly mention the oath of the ambassadors without any details. The most interesting feature is the clause determining that the ambassadors were to receive a copy of the decree, with their names registered on it, sealed with 
an official seal carrying the image of Dionysos, Maroneias' principal deity, which they desired

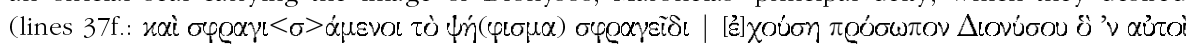

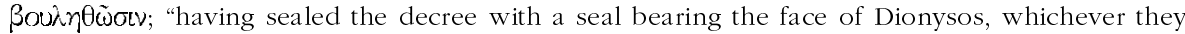
themselves wish"). The second fragmentary decree concerns a new embassy to the emperor, giving instructions to the ambassadors on how they were to behave in the emperor's presence. The decree stipulates that the ambassadors (lines 21-31) and all the citizens of Maroneia (lines 3140) were to take oaths. In the ambassadors' oath, the divine emperors and the senate are invoked first, followed by the formula "and all the other gods". The oath of the Maronites invokes first "all gods and goddesses", followed by Augustus, Tiberius, Claudius, and the senate. [JM]

29) K. Clinton - O. Palagia, "The Boy in the Great Eleusinian Relief", $\operatorname{MDAI}(A) 118$

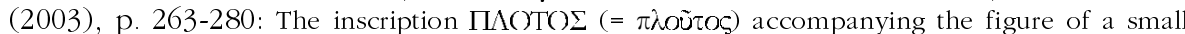
child on an Attic red-figure chous now in Berlin (Antikensammlung F 2661) should not be interpreted as a pet name of the child but as the name of the god Ploutos. The iconography of the child on the vase correlates to that of the boy on the so called Great Eleusinian relief. C.-P. interpret this figure as Ploutos as well. [JM]

30) V. Cojocaru, "Din nou despre 'Ahile la Tyras", Thraco-Dacica 22.1/2 (2001), p. 211-212 [German summary; SEG LII 749]: Ed. pr. of a graffito on the sherd of a vase

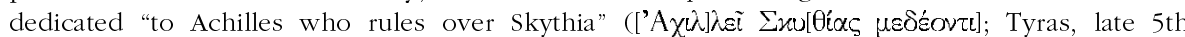
centt.). The cult of Achilles was already attested in Tyras (SEG L 715 bis; SEG LI 37). The

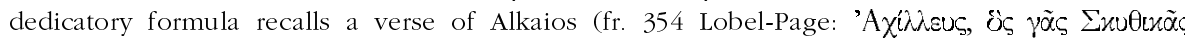

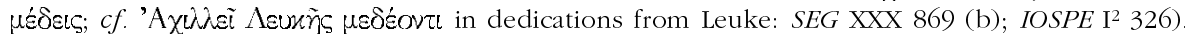
The new find calls for a reconsideration of the relations between the cult of Achilles in the North Shore of the Black Sea and Skythian mythological traditions. [AC]

31) T. Consten, "Prosopographische und onomastische Notizen", EA 35 (2003), p. 113122 [BE 2004, 262]: Four reliefs from Miletupolis in Mysia, three of them with dedicatory inscriptions (I.Miletupolis 12a-c, Imperial period), concern the cult of Meter. Apparently all four objects were dedicated by the same person, named Matron. C. offers a conclusive interpretation

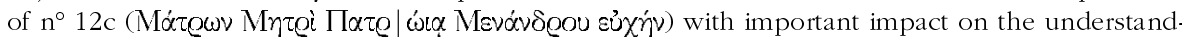
ing of the cult. According to C., Menandros is not the patronymic of Matron but the name of the founder of the cult: Matron (dedicated this) to Meter Patroa Menandrou in fulfilment of a vow. [On names of divinities followed by the name of the cult's founder see EBGR 2000, 108 (Dionysios Kallonos). Menandros, the founder of the cult, may nevertheless be Matron's father. Matron has a theophoric name deriving from Meter, and the epithet Patroia may be an allusion to the foundation of Meter's cult by Matron's father]. [JM]

32) J. Curbera - D. Jordan, "Curse Tablets from Pydna", GRBS 43 (2002/03), p. 109-127 [SEG LII 617; BE 2004, 12]: Ed. pr. of six lead curse tablets found in graves in Pydna (4th cent.). Three texts consist of names in the nominative (1: at least 13 names, one of which is a female name; 2: 15 names, of which at least 4 belong to women; 3: 5 names of men), the other three texts give information about the context (lawsuits). $\mathrm{N}^{\circ} 4$ is addressed against Euhippas, another

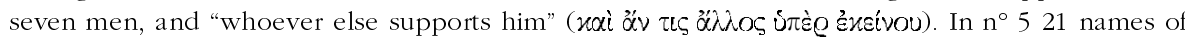
men (in the nominative) are followed by the phrase "and whoever is an advocate of Simmias and

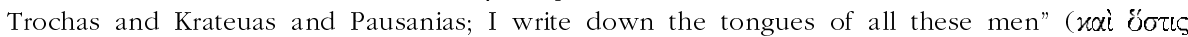

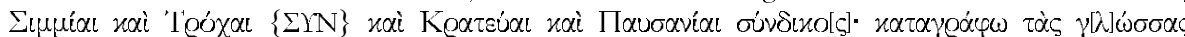

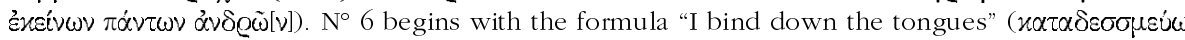
$\left.\tau \dot{\alpha} \varsigma \gamma_{\lambda} \omega \sigma \sigma \sigma \alpha c\right)$ followed by the names of six men and the phrase "and if another enemy rages for

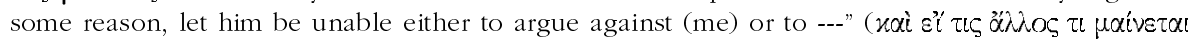

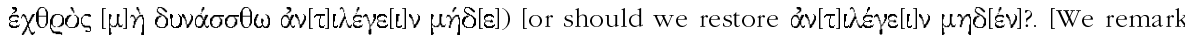

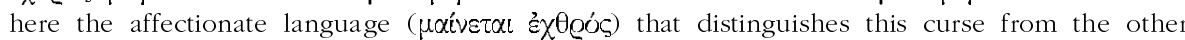
formulaic texts; as the editors point out, the verb 'rage' is new among fourth-century defixiones]. An Attic influence is possible, since the verb $x \alpha \tau x \delta \varepsilon \sigma \mu \varepsilon u ́ \omega$ occurs only in defixiones from Attika and Oropos; $x \alpha \tau \alpha \gamma \in \alpha \dot{\alpha} \varphi \omega$ is rare in Attika, but occurs in Arethousa in Macedonia (SEG XLVII 885; EBGR 1997, 271). [AC] 
33) H. Cuvigny, "Claudius Lucilianus, préfet d'Aile et de Bérénice ", in T. Gagos - R.S. Bagnall (eds), Essays and Texts in Honor of J. David Thomas, Oakville, CT, 2001, p. 171-174 [SEG LI 2134]: Ed. pr. of a dedicatory inscription, probably referring to the construction of a shrine in the praesidium at Didymoi (Egypt, AD 190); the building was a

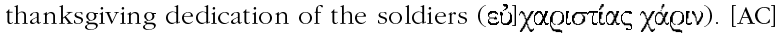

34) R. CZech-Schneider, "Das Apollonheiligtum von Aktion in hellenistischer Zeit: Überlegungen zum wirtschaftlichen Verhältnis zwischen Heiligtum und profanem Inhaber", Klio 84 (2002), p. 76-100 [SEG LII 481]: After an overview of the financial aspects of cult, in particular in the Hellenistic period, and of the history of Apollon's sanctuary in Aktion and its regional significance, C.-S. studies in detail the financial aspects of the treaty between the Akarnanian koinon and Anaktorion concerning the future status of the sanctuary as a sanctuary of the Koinon $\left(I G \mathrm{IX}^{2} .1,583 ; 216 \mathrm{BC}\right)$. The provisions of the agreement concern inter alia the financial aspects of this agreement, i.e., the expenses for the cult (repairs of buildings, contests, sacrifices, and musicians) and the revenues of the sanctuary (revenues from the festival and the property of the sanctuary, harbor taxes). C.-S. argues that the property of the sanctuary (dedications and sacred money) was rather limited and did not include land or buildings. This explains why the city of Anaktorion was unable to cover the cult expenses (repairs and festival), although it presumably had access to the sacred property and the other revenues. The Akarnanian Koinon was willing to take over the sanctuary and the financial burdens involved because it aimed at creating a cultural and political center. Clarification about the revenues was necessary because the sanctuary continued to be part of the territory of Anaktorion. [AC]

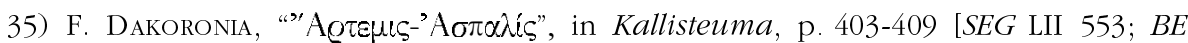
2004, 209]: Ed. pr. of a dedication to Ennodia by a woman, written on a marble base found in a small temple at Melitaia (Thessaly; c. 150-100 BC) [or rather c. 150; for the date see B. HeLLY - J.C. DeCOuRT, BE 2004, 209]. Archaeological finds (statuettes of Artemis and of a goddess with a torch) identify the cult as that of Ennodia-Artemis ( $c f . S E G$ XXVII 209) who was associated with the heroised Aspalis (cf. ANTON. LiB., Metam. 13). [AC]

36) R.W. Daniel, "Some Magical Gems in the British Museum", ZPE 142 (2003), p. 139142 [BE 2004, 80]: D. suggests new readings of the texts on magical gems in the British Museum published by S. Michel, Die magischen Gemmen im Britischen Museum, London, 2001. N 68: D.

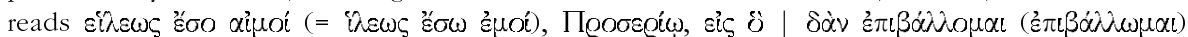

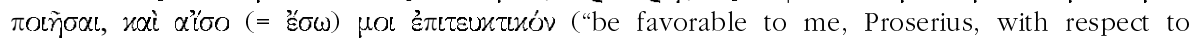
whatever I undertake to do, and be for me a promoter of success"). $\mathrm{N}^{\circ} 159$ : The name is

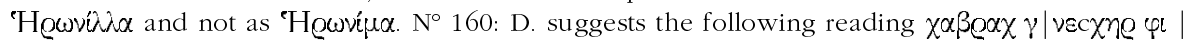

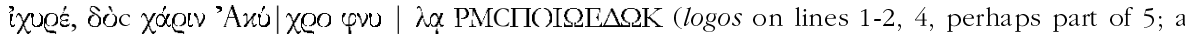

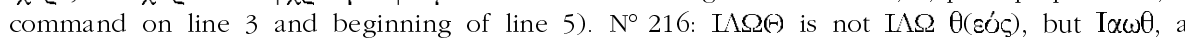
common name for gods, angels, and demons in $-\omega \theta$. $\mathrm{N}^{\circ} 304$ : The vox magica $\triangle \Lambda \Lambda \mathrm{MBHT} \Omega P$ occurs also in PGM IV 281 and is not a novum as suggested by MiCHEL. N $\mathrm{N}^{\circ}$ 546: ГП $\Delta \Phi I() \triangle(\Theta I T() C$ does not contain the otherwise unattested name Aphiodotos, but should be

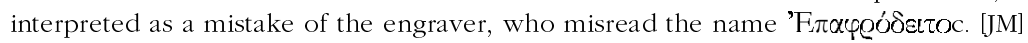

37) G. DAverio Rocchi, "Topografia dello spazio internazionale. La hierà hodós da Atene a Delfi", in Stuttgarter Kolloquium 7, p. 148-159 [SEG LII 32 and 518]: Analysis of

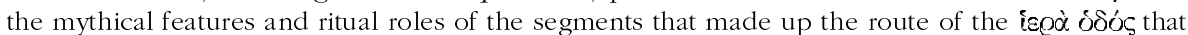
lead from Athens to Delphi, via Eleusis and Panopeus ( $c f$. IG $\mathrm{I}^{3}$ 791, 1096; IG $\mathrm{II}^{2}$ 1095, 1126, 2624; Agora III 730; Agora XIX H34; F.Delphes III.2, 138; CID I 10). [AC]

38) L. Del Verme - G. SACco, "Cuma: Frammenti ceramici iscritti dagli scavi dell'Orientale", Annali di Archeologia e Storia Antica 9/10 (2002/2003), p. 251-270: The authors present inscribed sherds found in the area of the late Archaic fortifications of Kyme. One of the

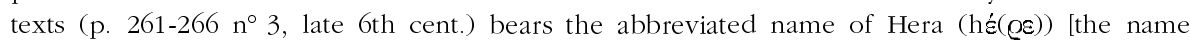
should be restored in the genitive, rather than in the nominative ('belonging to Hera')]. Vases inscribed with the name of Hera had already been found in Kyme (SEG XIII 898), Elea/Velia (SEG L 1071), and Poseidonia (G. SACCO, "Le epigrafi greche di Paestum lucana", in M. CIPRIANI - 
F. LONGo [eds], I Greci in Occidente. Poseidonia e $i$ Lucani, Naples, 1996, p. 206f.). The cult of Hera was attested in Kyme through an oracular response (SEG XL 816, c. 650-600: hŕon củx ¿̇ã

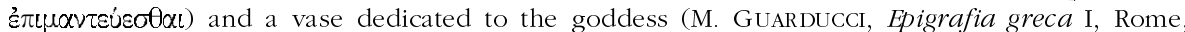

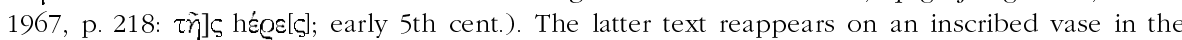
Museum in Baranello (SEG XL 817), which S. regards as a modern forgery. The sanctuary of Hera may be located in the area of Fondo Valentino. [AC]

39) M.W. Dickie, "Who Were Privileged to See the Gods?", Eranos 100 (2002), p. 109127 [SEG LII 1968]: The idea that a god appeared to virtuous persons (e.g., IG IV ${ }^{2} 128$ ) and the feeling that the god might take umbrage if he knew his sanctuary was desecrated by the presence of unworthy persons ( $c f$. CALLIM, $b$. Apoll. 1-11) lead D. to the assumption that the regulations against the presence of ritually impure and morally stained persons in sanctuaries (e.g., SEG XLIII 710; LSAM 29; LSCG Suppl. 59 and 108; cf. EBGR 1997, 71) are connected with the anxiety aroused by the imminent arrival of the god. [These regulations forbid the presence of unworthy people not only on the day of a festival, but in general, and consequently, this cannot be the only explanation for the development of the idea of a moral impurity. To the evidence collected by $\mathrm{D}$. one should add the only text which explicitly states that the presence of an impure person disturbs the performance of rituals: LSAM 20 LL. 36-41 (Philadelpheia). On this subject see A. CHANIOTIS, "Rituals between norms and emotions: Rituals as Shared Experience and Memory", in E. Stavrianopoulou (ed.), Ritual and Communication in the Graeco-Roman World, Liège, 2006 (Kernos, suppl. 16), p. 211-238]. [AC]

40) B. Dignas, "Rhodian Priests after the Synoecism", AncSoc 33 (2003), p. 35-51: In a thorough study D. discusses many aspects of Rhodian priesthoods. Numerous inscriptions found show that the eponymous magistrate in Lindos was the priest of the Athana Lindia, in Kamiros the damiourgos of Hestia and Zeus Teleios, and in Ialysos (perhaps) the priest of Apollon Ere-

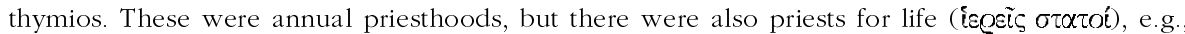
in the cult of Poseidon Hippios. After the Rhodian synoikismos and the foundation of the new city of Rhodos, Halios became the patron deity of the whole island and his priest the most important priest. According to inscriptions - most of them from Lindos - many priests of Halios had previously been priests of other cults, following in a way a priestly career (e.g., I.Lindos 1) [cf. the article of E. LIPPOLIS summarised in EBGR 1991, 149]. In Lindos the priesthood of Athana Lindia was apparently the culmination of such a Lindian cursus honorum. Epigraphic material from Kamiros and Lindos reveals the existence of a hierarchical structure of the cult personnel: In Kamiros, the damiourgos is named first, followed by the 12 bieropoioi and the archiaristas/archieristas. In Lindos the priest of Athana is followed by one or two priests of other cults and then by the archierothytas and his board of the nine bierotbytai. It seems that in Lindos, some time after the end of the $3 \mathrm{rd}$ cent., the bierotbyteion took over the function of the prytaneion as

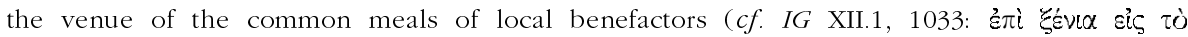

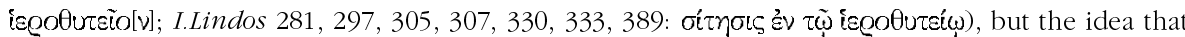
the hierothytai had taken over the function of the prytaneis should be rejected. D. collects also epigraphic evidence suggesting the existence of a "priestly" group identity: priests designated the priests of other cults serving in the same year as synhiereis (I.Lindos 131, 229, 248, 293, 344, 349, 378 ); the former priests of a given cult are frequently characterised as bierateukotes (not bierateusantes), the perfect tense emphasising the permanent status of priesthood (I.Lindos 346,

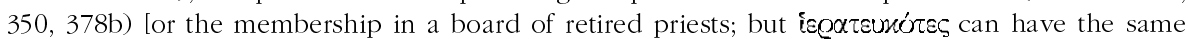

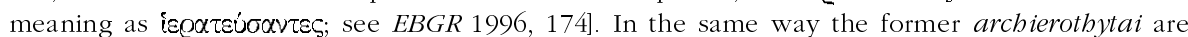
called archierothytekotes (cf. I.Lindos 346). Apparently at least in Rhodos the annual priesthoods were an important part of a priestly career which did not end after the term of office, while priests and cult personnel in general understood themselves as "fellow priests" (synhiereis). After discussing briefly the phenomenon of adoption in Rhodos and its Peraia (more than 500 cases of adoption from the middle of the 3 rd cent. onwards), D. suspects a connection between adoption

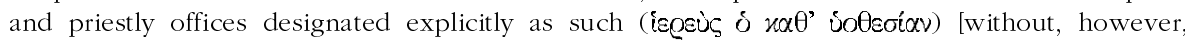
offering a convincing interpretation]. [JM] 
41) B. Dignas, "Urban Centres, Rural Centres, Religious Centres in the Greek East: Worlds Apart?", in E. SCHWERTHeIm - E. WinTER (eds), Religion und Region. Götter und Kulte aus dem östlichen Mittelmeerraum (Asia Minor Studien, 45), Bonn, 2003, p. 7791: D. rightly points out that no strict distinction should be made between urban and rural religious centers. The designation of a divinity as a patron of a community ( $\left.\pi \varrho 0 \varkappa \alpha \theta \gamma^{\prime} \mu \varepsilon v \circ c\right)$ is not confined to a rural context [but it may have been transferred from the urban centers to rural sanctuaries; for the strong representation of such epithets in the cities of the Imperial period see A. CHANIOTIS, supra n $^{\circ} 27$, p. 185 note 35 ]. Appeals to divine justice are not specifically connected with remote rural sanctuaries, but are in fact also attested in civic sanctuaries (e.g., of Demeter in Knidos). Similarly, the consignation ( $\alpha_{\left.\alpha \tau \alpha \gamma 0 \alpha \varphi \alpha^{i}\right)}$ of persons (slaves, children, nurslings) to deities [see EBGR 2000, 155 and 169; 2001, 124] is attested in Macedonia (Leukopetra) [EBGR 2000, 155, not accessible to D.] and in Kos (LSCG 171) in urban contexts [but in Macedonia perhaps in connection with a population substratum similar to that of rural Phrygia]. The epigraphic evidence from the sanctuary of Apollon Lairbenos in Phrygia [EBGR 2000, 169] reveals very complex relations between the sanctuary and the neighboring cities, in particular Motella (which seems to have administrated the sanctuary still in the 3rd cent. AD), Hierapolis, Dionysopolis, and Blaundos. Future prosopographical studies may show the activities of urban elites in rural sanctuaries. $[\mathrm{AC}]$

42) M.P.J. Dillon, "Did Parthenoi attend the Olympic Games? Girls and Women Competing, Spectating, and Carrying out Cult Roles at Greek Religious Festivals", Hermes 128 (2000), p. 457-480: D. plausibly argues that girls - unlike women - were allowed to attend the Olympic festival as spectators ( $c f$. PAUS. VI 20,9). They also competed in the Heraia at Olympia, a festival that probably attracted mainly or only local competitors. Women sponsored chariots at Olympia and elsewhere (e.g., $I G$ V.1, 1564 A). The prohibition against women spectators was a peculiarity of the Olympic Games. D. collects evidence for the participation of girls in athletic contests (F.Delphes III.1, 534 [for the date of this text see now EBGR 2002, 69]; SEG XIV 602; IAG p. 168), which seems to be a late development, as well as for the part played by physical training in the education of girls. A large part of his article deals exclusively with female festivals (Thesmophoria, Skira, Stenia, Haloa, Adonia; $c f$. LSCG 128, for a Dionysiac festival in Methymna), the performance of ritual roles by girls (e.g., the Athenian Praxiergidai; $c f . I G \mathrm{I}^{3} 7=$ LSCG 15; the alektrides, arktoi, arrhephoroi, kanephoroi, and hydrophroi in Athens), and the exclusion of women from certain cults (STRAB. XIV 6.3; PLUT., mor. 300d; PAUS. III 22, 7; VII 5, 8; FGrHist 26 F 1; 81 F 33; LSAM 42 A; LSCG 82, 96, 109, 110, 124; LSCG Suppl. 56, 63, 66, 88). [AC]

43) G. Di Vita Evrard, "Il Serapeo di Leptis Magna: Le iscrizioni latine", $Q A L 18$ (2003), p. 285-286: Among the inscriptions found during the excavation of the Sarapis temple in Leptis Magna, D. publishes three Latin texts: an altar dedicated to Sarapis and Isis (17), an altar dedicated by a man with the theophoric name Syrapiacus (= Serapiacus) in fulfilment of a vow (votum solvit), and an epitaph (19). [For the Greek dedications see infra ${ }^{\circ}{ }^{139}$ ]. [AC]

44) C. Dobias-Lalou, "Notes sur le Supplemento Epigrafico Cirenaico", QAL 18 (2003), p. 211-221 [BE 2004, 431]: Two fragmentary inscriptions from Kyrene (SECir 123 and 176, 4th/3rd cent.) belong to the same text; their joining shows that SECir 123 is not a dedication to the Dioskouroi (line 1: 'Av $\alpha$ \& [--]), but a dedicatory inscription recording the dedication of a stone

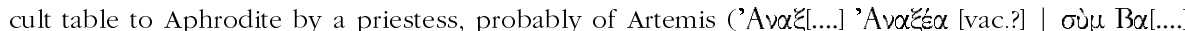

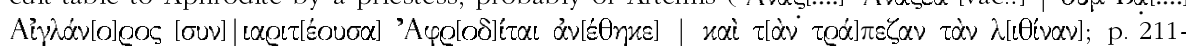

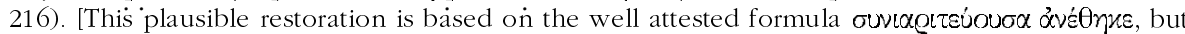

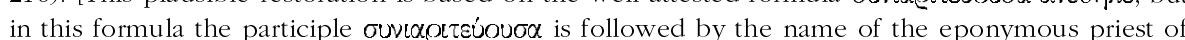

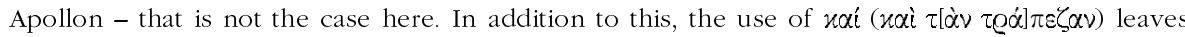
the possibility open that the priestess dedicated more than one object and that, consequently, the

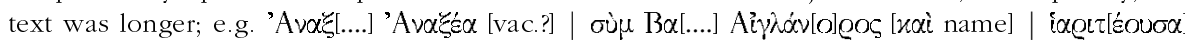

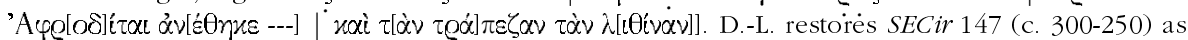
a dédication of two men and a woman to Apollon and Artemis (p. 219f.). SECir 258 (4th/3rd cent.) commemorates the dedication of the statue of Charitimos by a relative (son?, father?). [AC] 
45) I. Doncheva, "Iconographic features of Athena's Images on Votive Reliefs from Moesia and Thracia", Arheologija (Sofia) 43.3 (2002), p. 18-27 (Bulgarian; English summary) [SEG LII 657]: D. studies the iconography of Athena in votive reliefs from Thrace and Moesia in the Imperial period. The inscriptions reveal the official character of the cult and its relation to the emperor cult. Athena's worshippers in Thrace were primarily colonists of Eastern origin and veterans who were settled in Moesia Inferior and Thracia. Athena is represented both alone and in the company of other deities (Hermes, Zeus, Hera, and Hephaistos). Her iconography follows the types of Athena Promachos, Polias, Nikephoros, and Ergane. The representations of Athena, Zeus, and Hera are related to the worship of the Capitoline triad which is epigraphically attested, in particular in Nicopolis ad Istrum. [AC]

46) N. Ehrhardt, "Poliskulte bei Theokrit und Kallimachos: das Beispiel Milet", Hermes 131 (2003), p. 269-289: Two Milesian cults mentioned by Hellenistic poets, the cult of Aphrodite at Oikous (THEOCR., Id. 7, 116) and that of Athena Chitone (CALlim., bymn. in Dianam 225-227), are placed by E. in a historical context. The sanctuary of Aphrodite, one of the most important sanctuaries of Miletos since the Archaic period (cf. POSEIDIPPOS, Anth. Pal. XII 131), has been located at Zeytintepe (see EBGR 1994/95, 163 and 169; SEG XLIII 846; XLV 1613). Theocritus must have seen the sanctuary when he visited Miletos ( $c f$. Id. 28). The mention of this sanctuary in his poem was a homage to his Milesian friends. In the case of Callimachus, the reference to the cult of Athena Chitone (sc. Kithone; see LSAM 51; SEG XXXVIII 1213; cf. EBGR 1988, 63 and 1998, 119) should not be attributed to his well attested interest in Milesian cults, but to his effort to describe the extension of the power of Ptolemy II by mentioning important cults of areas under Ptolemaic control (Ikaros, Perge, Miletos, Samos, and Ephesos). [On the close connection between Callimachus' poetry and contemporary cults see EBGR 2001, 33]. [AC]

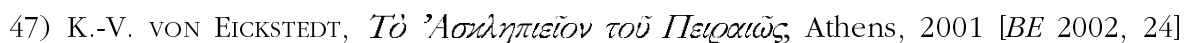
Study of the history of the cult of Asklepios in Athens, with particular emphasis on the sanctuary in Piraeus; E. collects the evidence for the rituals (esp. sacrifices) and the cult personnel ( $c f . I G \mathrm{II}^{2}$ 47, 4538, 4589, 4618, 4621, 4639, 4962; I.Oropos 344). [AC]

48) G. Еквотн, "Inventing Iphigeneia? On Euripides and the Cultic Construction of Brauron", Kernos 16 (2003), p. 59-118: After a thorough study of the archaeological, literary, and epigraphical evidence concerning the sanctuary of Artemis Brauronia, E. shows that the presence of Iphigeneia in Brauron is a creation of Euripides based on features of divinities already present at the sanctuary. E. argues that the importance of the arkteia for Athenian society and the construction of the great stoa - finished around $420 \mathrm{BC}$ - could have drawn the attention of Euripides on Brauron. In a useful appendix (p. 102-118) E. discusses the historical development of Brauron on the basis of the archaeological material and the important inscription [cf. $E B G R$ 1996, 29 and 194] documenting reconstruction work in the sanctuary [E. could not take into consideration the relevant article by P. THEMELIS summarised in EBGR 2002, 144]. [JM]

49) A. Farnoux, "Homère à Délos", Ktema 27 (2002), p. 97-104 [SEG LII 759]: A study of the evidence on the Homereion of Delos (I.Delos 433 Bd 147) and of the literary traditions on the relations of Homer to Delos leads F. to the assumption that the Homereion was not a gymnasium, but a small building of unknown location that housed the poet's statue, but not necessarily his cult. In the Hellenistic period the Delians attempted to appropriate Homer. [AC]

50) D. FeISSEL, "Ėres locales et frontières administratives dans le Proche-Orient protobyzantin", in K. BelKe et al. (eds), Byzanz als Raum. Zu Methoden und Inhalten der historischen Geographie des östlichen Mittelmeerraumes, Vienna, 2000, p. 65-74 [SEG LI 2005-2006]: F. briefly discusses two dedications to Zeus Tour Barachos (p. 70 with note 40; Srîr in Syria, AD 131 and 134; J. JARRY, Annales Islamologiques 7 [1968], p. $164 \mathrm{n}^{\text {os }}$ 44/45). determining their date and arguing that the sanctuary was located on the boundary between the Antiochene and the Chalkidene. [AC]

51) N. Franken, "Lampen für die Götter. Beobachtungen zur Funktion der sogenannten Vexillumaufsätze", MDAI(I) 52 (2002), p. 369-381 [SEG LII 1858-1860; BE 2004, 83]: F. collects bronze lamp hangers from the Roman East (3rd cent. AD), formerly interpreted as parts of 
army banners. The dedicatory inscriptions, which are addressed to Theos Hypsistos (SEG XXX 1791; LII 1859, from Hypaipa?; LII 1858) and Zeus (IGBulg V 5261, from Novae), show that these objects were used in the cult of these gods ( $c f$. TAM V.2, 1400). One of the inscribed lamps was dedicated by an association of traders (SEG LII 1860). [AC]

52) P.M. Fraser, "Agathon and Kassandra (IG IX.12 4.1750)", JHS 123 (2003), p. 26-40: F. discusses an interesting inscribed bronze plaque from the sanctuary of Zeus at Dodona (IG $\mathrm{IX}^{2}$.1, 1750; late 4th cent.). The bronze plaque was a gift sent to the sanctuary at Dodona by the

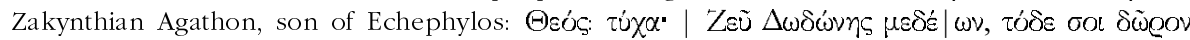

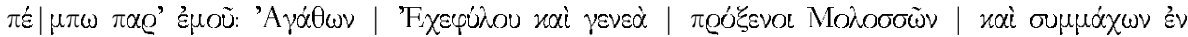

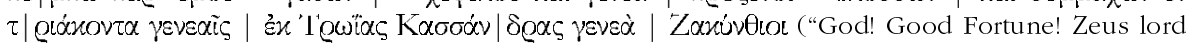
of Dodona I send this gift to you from me: Agathon, the son of Echephylos, and his offspring, proxenoi of the Molossians and their allies throughout thirty generations from Troy, the race of Kassandra, Zakynthians") [the last three lines are interupted by a phallus in relief]. F. demonstrates that the gift was sent to Dodona upon a renewal of the apparently hereditary proxenia of Agathon and his family. In this context Agathon tried to create a link to the Molossians and the sanctuary of Dodona going back to mythical traditions connected to the Trojan War. F. suggests that Agathon and his family traced their origins back to the brother of Kassandra, the Trojan Agathon. The depiction of the phallus is according to F. not apotropaic, but a symbolic demonstration of Agathon himself as a vital junction between the past and the future of his family. [JM]

53) P. Gauthier, "Deux décrets hellénistiques de Colophon-sur-mer", REG 116 (2003), p. 470-493 [BE 2004, 284]: Ed. pr. of two honorary decrees of Kolophon (3rd cent.) found in the sanctuary of Apollon at Klaros. The first decree honours Sosias, son of Sokrates, from Herakleia, giving him inter alia the right of access to the council and the assembly immediately

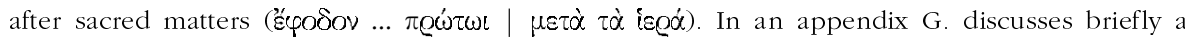
Kolophonian decree for a man from Temnos (L. ROBERT, OMS II 1245-1247) who was honoured for reporting a sacrilege against the sanctuary of Meter. G. suggests that the decree refers to the Metroon of New Kolophon, although the inscription was found during excavations in the old city. [JM]

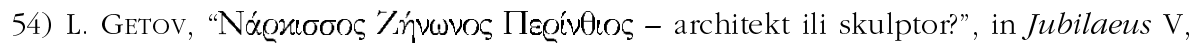
p. 109-110 [SEG LII 701]: The sculptor Narkissos of Perinthos (SEG XLII 647, c. 150 AD) was not the architect of the temple of Herakles Agoraios in Kabyle (IGBulg V 5636, 144 AD), but made the sculptures in this sanctuary. [AC]

55) V. GHEzzI, "Una svolta politica a Siracusa. L'iscrizione del tempio di Apollo e le leggi suntuarie", Acme 55.2 (2002), p. 115-124 [SEG LII 935]: G. discusses the dedicatory inscription on the temple of Apollon in Syracuse (c. 600-575; IG XIV $1=$ IGDS 86; $c f$. SEG XLVI

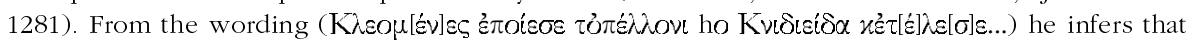
Kleomenes cannot have been the architect; he must have been a member of the wealthy class of the gamoroi, who had been assigned the task of supervising the building of the temple. He may have inspired the story narrated by Diodoros (8.11) about an epistates (Agathokles) who appropriated the most beautiful stones for the building of his own house. [But this person was sentenced to death. Why should the Syracusans keep the inscription that reminded them of the epistates' crime?]. The introduction of sumptuary laws in 6th cent. may have been a response to ambitious men such as Kleomenes. [AC]

56) M. Girone, "Per un lessico del furto", Annali della Facoltà di Lettere e Filosofia di Bari 44 (2001) [2002], p. 183-200 [SEG LII 2002]: In an overview of the large variety of terms related to theft, $G$. briefly mentions the references to theft in the healing miracles of Epidauros (IG IV 2121 VI-VII; p. 184/185) and in a confession inscription (BIWK 3; p. 199); she also briefly considers epithets of Athena that allude to war booty (Leitis, Syleteira, Skyletria) and the

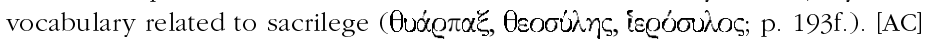

57) M. Girone, "Una particolare offerte di chiome", EA 35 (2003), p. 21-42 [BE 2004 , 314]: At least 100 inscriptions from Stratonikeia (I.Stratonikeia 42, 401-420, 422-469, 472-475, 477, 
$478,480,481$, and 483-500) attest to the practice of hair dedication to Zeus Panamaros during the Imperial Period. According to G. after the miraculous salvation of Panamara by Zeus Panamaros during the siege of the city by Labienus' troops (42 BC; $c f$. I.Stratonikeia 10), the Stratonikeis organised competitions to honor the god and introduced the practice of annual hair dedication during the festival of the Komyria. In G.'s view the dedicators were participants or winners at these competitions [but this cannot be confirmed by the inscriptions]. [JM]

58) Z. GočEva, "Kaiserkult in Nicopolis ad Istrum", in The Roman and Late Roman City, p. 81-84 [SEG LII 717]: G. collects the epigraphic and numismatic evidence for the emperor cult [only part of the evidence she discusses is related to the emperor cult, since she fails to make a distinction between dedications and honorary inscriptions for emperors]. The fact that the hymnodoi served both in the cult of the Capitoline Triad (Zeus Olympios, Hera Zygia, and Athena Polias) and in that of the emperor leads G. to the conclusion that the two cults were connected. For this reason $G$. assumes that the local high priest and high priestess were also responsible for the cult of the Capitoline Triad. [AC]

59) Z. GočEva, "Svetilisteto pri Glava Panega i problemat za romanizacijta na Dolna Misija", in Jubilaeus V, p. 111-118 (in Bulgarian): G. studies the iconography of the dedicatory reliefs found in the sanctuary of the Thracian Rider God (Heros, Heros Saldobysenos, Saldokelenos, Saldenos) at Glava Panega (cf. IGBulg II 510-586). This divinity was later assimilated with Silvanus and Asklepios (Saldobysenos, Saldokelenos, Saldenos, kyrios, epekoos), worshipped together with Hygieia and Telesphopros. Artemis was also worshipped here (as Saldobysene) as well as a female companion of the Rider God (Kyraikne). The sanctuary primarily attracted Thracian worshippers . [AC]

60) GORNy \& Mosch, Giessener Münzhandlung, Auktion 124. Kunst der Antike. Dienstag, 27. Mai 2003, Giessen, 2003: This catalogue of an auction of antiquities includes several inscribed objects, identified for us by J. Bauer (Vienna). A bronze applique represents the Tyche of Kaisareia in Kappadokia; on her head she bears a crown representing the city walls; a figure on the crown offers a wreath to a personification of Mt. Argaios. From the inscription, only

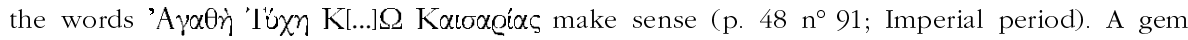
made of hematite represents Abrasax on the obverse [one recognises the inscription I $\alpha \omega$ in his shield, $\Sigma \alpha \beta \alpha \epsilon^{\prime}(\theta)$ under his legs, A above his head and $\Omega$ on his left], and the magical names

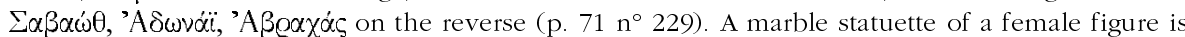
inscribed on the base (p. $96 \mathrm{n}^{\circ} 367,2 \mathrm{nd} / 3 \mathrm{rd}$ cent.). [We read the text as follows: ['F $\pi$ ] $\alpha \rho \subset \tilde{\alpha} \subseteq \varkappa x \tau$ '

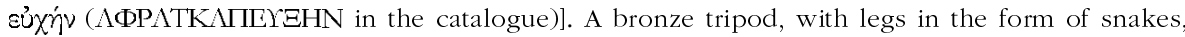
supporting a bowl was used in the cult of Asklepios and Hygieia ('Y yi $\alpha \varsigma$, 'A $\sigma \lambda \lambda r \pi\llcorner O \tilde{\text {; }}$ p. 112 $\mathrm{n}^{\circ}$ 442; from the Eastern Mediterranean, Imperial period). [AC]

61) GORny \& Mosch, Giessener Münzhandlung, Auktion 128. Kunst der Antike. Samstag, 13. Dezember 2003, Giessen, 2003: We present two of the objects offered for sale. A bronze plaque has the form of an aedicula, with a seated Apollon of the type of the cult statue of Apollon Klarios in the aedicula; the monogram $\Pi \Lambda$ is on its back (unknown provenance, Imperial period, $107 \mathrm{n}^{\circ}$ 480) [for similar objects (or the same object?) see EBGR 2002, 52 and 53]. A dedicatory relief representing Hekate with three bodies offering sacrifices (Eastern Mediterranean, 2nd/3rd cent.) was dedicated by a decurio (p. $113 \mathrm{n}^{\circ} 355$ ) [we read the text: $B \alpha \lambda \dot{\varepsilon}(c\llcorner 0 c)$

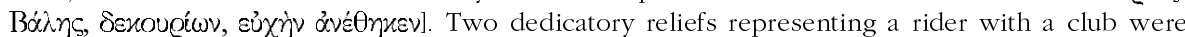
dedicated as vows (p. $114 \mathrm{n}^{\text {os }} 357$ and 358, 1st/2nd cent. A.D.). [We read the texts as follows:

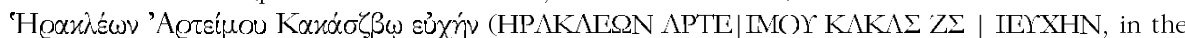

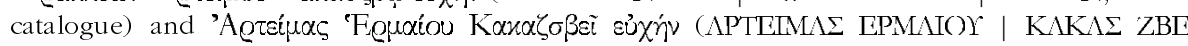
IEYXHN, in the catalogue). The vows were addressed to the Anatolian god Kakasbos/Kakasbeus, which makes a provenance from south Asia Minor probable; the dedicants seem to belong to the same family (perhaps father and son)]. A marble relief plaque represents two oxen on either side of a vase; above them an inscription (p. $114 \mathrm{n}^{\circ} 359$; North Syria, 1st cent. BC). [It is a dedication

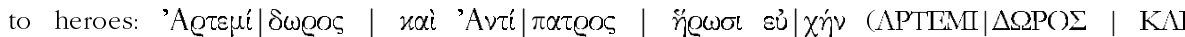
$\Lambda \mathrm{NTI} \mid \Pi \Lambda T P O \Sigma$ HPQSIE|XHN, in the catalogue]. [AC] 
62) A.J. Graham, "Thasos and the Bosporan Kingdom", Ancient West and East 1 (2002), p. 87-101 [SEG LII 740; BE 2003, 393]: G. presents a new critical edition and commentary of the metrical dedication of Leukon I, king of the Bosporan kingdom, to Apollon ( $\Phi$ cí $\beta \omega$ t

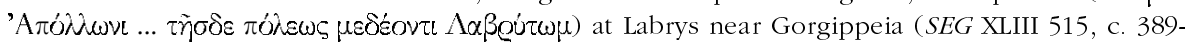
349). The dedication was made after Leukon's victory in a war against those who had expelled Hekataios, king of the Sindians, from his throne. [AC]

63) Y. Grandjean - F. Salviat, "Travaux de l'École française en Grèce en 2001 Thasos", BCH 126 (2002), p. 519-522 [SEG LII 814]: An inscription which may refer to suppliants or supplication (on line 8 perhaps a form of $i x[\varepsilon \dot{\varepsilon} \tau \alpha] \iota$ or $i x[\varepsilon \sigma]^{i}(\alpha)$ was found near the theater of Thasos (5th/4th cent.). [AC]

64) W. GÜNTHER, “'Unsterbliche Kränze'. Zur Selbstdarstellung milesischer Propheten in didymeischen Inschriftendenkmälern", Chiron 33 (2003), p. 447-457 [BE 2004, 296]: Ed. pr. of a fragmentary inscription found in Didyma (1st cent.). The fragment seems to be the middle (?) part of a list of prophets in the sanctuary of Apollon at Didyma; the entries do not follow a strict chronological order. Three entries are preserved. From the first entry, only [--] $\tau i \delta \tilde{\nu} v$ is still visible. The second entry concerns the prophet Theokrines, son of Theokrines, natural son of Antigonos, who served during the stephanephorate of Simos and Apollonios (58 BC). The third entry, the longest and most important, concerns Antiochos, son of Antiochos, prophet in 52 BC:

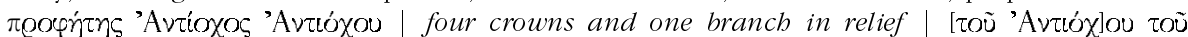

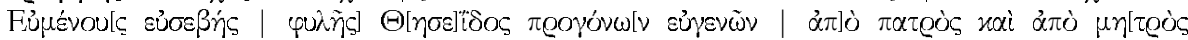

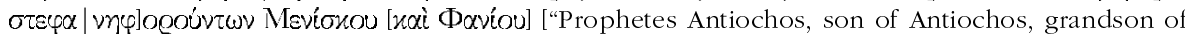
Antiochos, great grandson of Eumenes, pious, member to the phyle Theseïs, of noble ancestors both on the father's and on the mother's side, during the stephanephorate of Meniskos and Phanios"]. A significant detail is the depiction of the four crowns, for which there is a significant parallel: IvDidyma 229 II concerns the prophet $66 \mathrm{BC}$, Philodemos, son of Pamphilos. Above the inscribed text four different crowns are depicted in relief, and L. ROBERT (Hellenica 11/12 [1960], p. 449-453] suggested that they could represent the symbols of the offices of the prophetes and the stephanephoros that Philodemos held simultaneously in $66 \mathrm{BC}$. Based on the new inscription, G. interprets the crowns as variations of the symbols of office of the Didymaean prophets. They

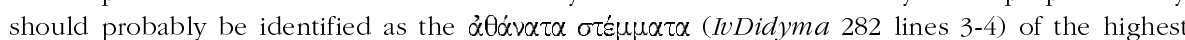
officials in the sanctuary of Apollon Didymaios. [JM]

65) L. Hannestad, "Gods and Agriculture: Evidence from an Agrarian Settlement in the North-Western Crimea", in Studies Skydsgaard, p. 143-151 [SEG LII 743]: In a report on the excavations of the rural settlement at Panskoye (Chora of Chersonesos), H. presents archaeological evidence related to the worship of patrons of agriculture in a house sanctuary (Demeter, Aphrodite, Sabazios, Eros?). The finds include a black glazed cup-skyphos dedicated to

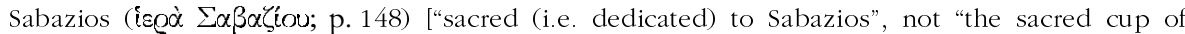
Sabazios"]. [AC]

66) C. Hasenohr, "Les Compitalia à Délos", BCH 127 (2003), p. 167-249: Based on a thorough discussion of the epigraphic evidence, altars and relevant paintings (35 examples of altars and paintings concerning the Compitalia) on the external walls of about twenty Delian houses and shops and the internal ones of three houses, H. convincingly shows that during the celebrations of the Compitalia on Delos in the 2nd and 1st cent. Herakles and other divinities, such as Hermes, Pistis, and Rome, were worshipped together with the Lares. It seems that the owners of the houses themselves for private sacrifices commissioned the altars and paintings. The epigraphic evidence from the Agora of the Competaliasts attest to a celebration of the Compitalia by the community of the Italici. [JM]

67) M.B. Hatzopoulos, "Artemis Agrotera Gazoreitis et Bloureitis, un déesse thrace en Macedoine", in Iıtúr. Studia in honorem Prof. Ivani Marazov, Sofia, 2002, p. 243-248 [SEG LII 648]: H. republishes a dedication to Artemis Agrotera Gazoreitis Bloureitis (Skydra, AD 106; SEG XVII 317), pointing out that there is no lacuna between the two fragments of the

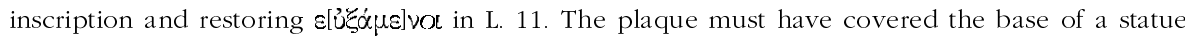


of Artemis. The epithet Gazoreitis derives from Gazoros which should be located in the area

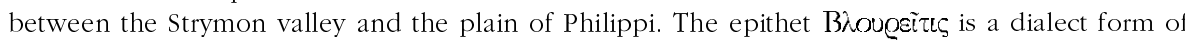

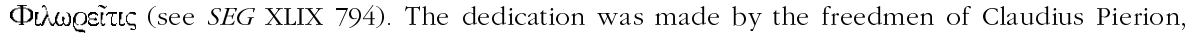
grandson of an homonymous high priest of the Macedonian Koinon (I.Beroia 40, 115/116, 123), Iulia Menneis, who possessed land north of Skydra and west of Kyrrhos, and by Popillia Sosipatra. The origin of the dedicants may have been Odomantike or Edonis, where the cult of Artemis Gazoria was popular. Perhaps the erection of her statue in Skydra signified the introduction of her cult, with the epithet Gazoreitis, which was added to the preexisting epithets Agrotera and Bloureitis. It is not clear whether the goddess was at that point a Thracian or a Hellenised divinity. [AC]

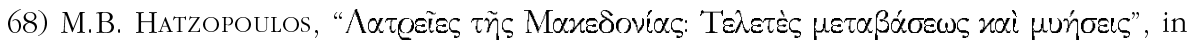
Latreies, p. 11-29 [SEG LII 586 and 606]: Recent research has shown the Greek character of the divinities worshipped in Macedonia (Artemis, Asklepios, Herakles Kynagidas and Patroios, Meter Theon, and Zeus). The cults of a great mother goddess, Dionysos, and Artemis are connected with initiatory rites for girls and young men (cf. EBGR 1993/94, 110). The concepts of afterlife in Macedonia is associated with the Dionysiac-Orphic mysteries, evidence for which has found in Macedonia in recent years (SEG XXXI 633; XL 541; XLV 762, 782/783; LI 788; cf. EBGR 1992,$128 ; 1993 / 94,104 ; 2001,118$ ). H. (p. 28) presents a new text, recently found in a grave at

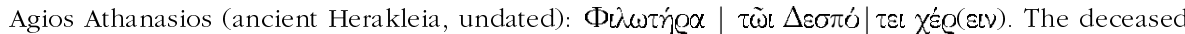

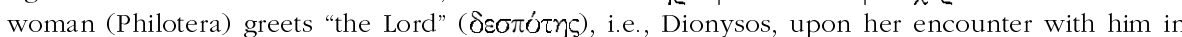
the underworld, requesting her acceptance among the blessed. [But in the Orphic texts the deceased person addresses Persephone and Plouton (e.g., SEG XLVIII $1227=E B G R$ 1998, 89:

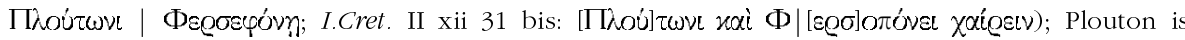
called $\delta \varepsilon \sigma \pi \dot{c} \tau n$ c as the ruler of the Underworld]. [AC]

69) W. HeLD, "Neue und revidierte Inschriften aus Loryma und der karischen Chersones", EA 36 (2003), p. 55-86 [BE 2004, 321]: H. presents texts, translations, and photographs of newly discovered and rediscovered inscriptions found during an archaeological survey

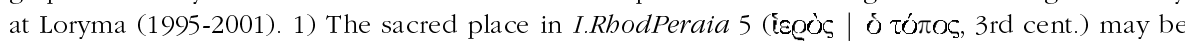
the sanctuary of Zeus Atabyrios. 2) New edition of a sacrificial regulation for the cult of Zeus Atabyrios (I.RhodPeraia 1, 3rd cent.) and an altar for Zeus Atabyrios (I.RhodPeraia 2, 3rd cent.). 3) Ed. pr. of a dedication to Artemis by Xenotimos of Karpathos, first epistates and taxiarchos, and Hagetor of Tlos (3rd cent.). 12) Ed. pr. of an inscription referring to a sanctuary of Artemis

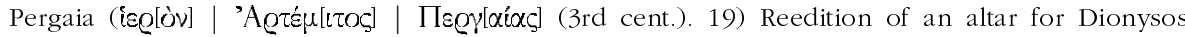
Narthakophoros (I.RhodPeraia 4, 4th/3rd cent.). 26) Reedition of a dedication to Theoi Pantes (?, I.RhodPeraia 35. 30-31) Ed. pr. of small fragments of Hellenistic (sacred) land leasing contracts from the sanctuary of Apollon Samnaios in Amos (cf. I.RhodPeraia 352-354) [and EBGR 2002, 10 = SEG LII 1029-1030]. [JM]

70) P. Herrmann - H. Malay, "Statue Bases of the mid Third Century A.D. from Smyrna", EA 36 (2003), p. 1-10 [BE 2004, 274]: Ed. pr. of six honorific inscriptions for governors of Asia and other members of the imperial administration from Smyrna. The dedicants of four statues were two hitherto unknown high priests of the provincial emperor cult: the Asiarch Quintilius Eumenes (1-3, c. 242-245) and the Asiarch and neokoros of the emperors M. Sellius Hieron (4, c. AD 236-238 or 250/51). The dedicant of a fifth statue, M. Claudius Apellas, was the son of an unknown Asiarch (5). The proconsul L. Egnatius Victor Lollianus (1-2; AD 242/3-244/5) was already known also as agonothetes of the contest of the Koina Asias in Smyrna ( $\pi 0 \tilde{\omega} \tau$ )

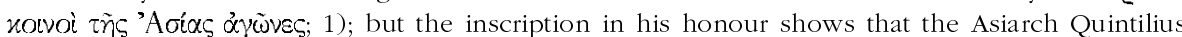
Eumenes served together with Lollianus as agonothetes of the contest (auvajwuvofítrc). Another honorary inscription set up by Eumenes for the philosopher Appius Alexandros (3) states that

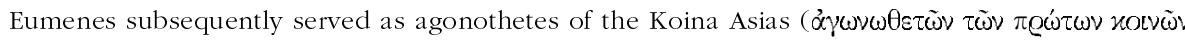

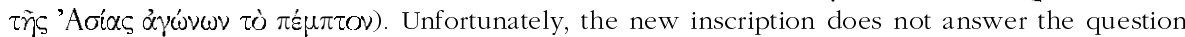
of the periodicity of the Koina Asias (cf. I.Smyrna 635). The inscription set up by M. Claudius

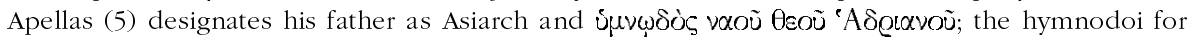
the cult of Hadrian were introduced in $\mathrm{AD} 123$. The peculiarity of the new text is that it mentions 
explicitly the temple of Hadrian [and confirms B. BuRRELL's view that Hadrian's temple in Smyrna was separate from that of Zeus Olympios; see supra $\mathrm{n}^{\circ} 22$ ]. [AC]

71) V. Hirschmann, "Der Schatten der Unsterblichkeit. Der Priester und Prophet Epitynchanos", EA 36 (2003), p. 137-152 [BE 2004, 350]: H. returns to the enigmatic epigram honouring Epitynchanos (AD 313/14, Phrygia; SEG XLIII 943B; SGO III 16/31/10; cf. EBGR 1997, 104; 1999, 161) elaborating on the suggestion by R. Merkelbach and J. Stauber ( $c f . E B G R$ 1999, 161) that $\dot{\alpha} \theta \dot{\alpha} \vee \propto \tau \varnothing c$, a title used by Epitynchanos and his brother Diogas, alludes to the immortality achieved through the initiation in a mystery cult. In a very complex analysis, in which $\mathrm{H}$. adduces many literary, epigraphic, and iconographical parallels, she suggests associating this text to a mystery cult closely connected with the Mithraic mysteries ( $c f$. the terms $\dot{r} \lambda$ loo $Q 0$ ó $\mu \circ$, , i.e. the second rank in the Mithraic mysteries) and the Orphic theogony. Epitynchanos was honored by Hekate, Manes Daos (according to legend, a son of Zeus and Ge), and Apollon through the

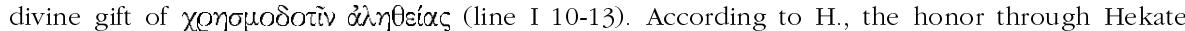
alludes to the rank of a perses in the mysteries of Mithras, while Manes Daos is the mystical name of the Orphic Dionysos. The figures represented on the monument may be Helios, Apollon, and Phanes. [JM]

72) A. Hollmann, "A Curse Tablet from the Circus at Antioch", ZPE 145 (2003), p. $67-$ 82 [BE 2004, 379]: Ed. pr. of a lead curse tablet (5th-6th cent.) discovered in 1934 in the circus of Antiocheia on a limestone block in a trench close to the curved end of the hippodrome. The text consists of sixty-one lines with curses against the horses of the Blues. Thirty-six of these horses are explicitly named, while none of the charioteers is named or even mentioned. The curse begins with a lengthy invocation of deities (lines 1-45), the actual request follows in lines

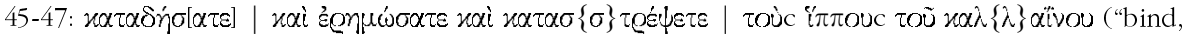
destroy, and utterly subdue the horses of the Blue faction"). Lines 47-61 list the names of the horses. The first line of the defixio contains a reference to the Samothrakian Great Gods. The defigens invokes Arxieris, Kadmilos, Arxierissa, and Kadmilos, whose names recall the names of the four Kabeiroi Axieros, Axiokersa, Axiokersos, and Kasmilos. One also observes allusions to the Eleusinian Mysteries through the invocation of Demeter (lines 5 and 10) and Persephone (lines 2 and 27). Zeus appears four times (lines 2, 7, 8, and 10). Poseidon, who does not belong to the normal repertoire of invoked divinities appears twice (lines 3, 10). The joint invocation of Dionysos, Zeus, Poseidon, Plouton, and Demeter (line 10) seems unparalleled. Dionysos is addressed in line 6 as the leader of the Korybantes. Line 40 contains the otherwise unattested

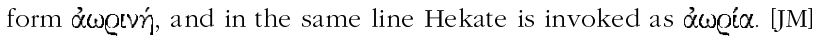

73) T. Howe, "Pastoralism, the Delphic Amphictyony, and the First Sacred War: the Creation of Apollo's Sacred Pastures", Historia 52 (2003), p. 129-146 [BE 2004, 186]: H. aptly underlines the importance of specialised pastoralism in Central Greece, arguing that the development of the sacred land of Apollon in Delphi as an area of protected pasture ( $c f$. CID I 10) is connected with the particular needs of the sanctuary for sacrificial animals. [AC]

74) B.G. Intzesiloglou, "Aiatos et Polycléia. Du mythe à l'histoire", Kernos 15 (2002), p. 289-295 [SEG LII 561; BE 2004, 214]: Ed. pr. of a roof tile with an engraved inscription found in a Mycenaean grave near Metropolis (7th/6th cent.): [---]气 Aiarílcv? F[---] (sc. a shrine of Aiatos). The grave was used as a sanctuary in the Archaic period, possibly of the Heraclid Aiatos, the father of Thessalos, the eponymous hero of the Thessalians. His cult in Metropolis explains the city's name, as the metropolis of the Thessalians. The new find allows us to locate the myth of Aiatos and Polykleia in the area of Metropolis and shows that the Mycenaean tomb was not used for the worship of an anonymous hero, but for that of a specific person. [AC]

75) C. Intzesiloglou, "The Archaic Temple of Apollo at Ancient Metropolis", in Excavating Classical Culture, p. 109-115 [SEG LII 562]: Ed. pr. of a stele supporting a bronze statue found in the cella of the temple of Apollon in Metropolis (Thessaly, 4th cent.).

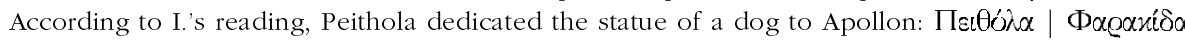
| xúva "A Apollon"]. [AC] 
76) S. Isager, "Halikarnassos and the Well of Aphrodite. On EM 199, Text and Provenance", in Studies Skydsgaard, p. 153-158 [SEG LII 1042]: The provenance of a stele with a list of contributors to the construction of a well, traditionally attributed to Theangela, is Halikarnassos (SEG XLVII 1611; early 2nd cent.). The text is dated by the name of the priest of Apollon Archegetes of Halikarnassos. Consequently, the priest of Aphrodite, named first among the contributors, served in Halikarnassos and not in Theangela that the first sponsor was a priest of Aphrodite is only an indication and not a proof that the well was constructed in a sanctuary of Aphrodite]. Apollonios, who contributed 30 workers, may be identified with the priest of Hekate Laginitis, who dedicated a sanctuary and an altar to the goddess during his term in office (unpublished inscription). [AC]

77) W. Johannowsky, Il santuario sull'acropoli di Gortina II, Athens/Rome, 2002 [SEG LII 859; BE 2003, 172]: Among the finds of an excavation in the sanctuary on the acropolis of Gortyn conducted in the 1950s [cf. infra $\left.\mathrm{n}^{\circ} 105\right]$, J. publishes two inscribed objects: a pinakion with floral decoration and the name of the dedicant (?, Euthetos) painted on it (p. $15 \mathrm{n}^{\circ} 70$, 8 th/7th cent.) and a fragmentary miniature clay shield with a graffito (21 $\mathrm{n}^{\circ} 144$, 6th cent.:

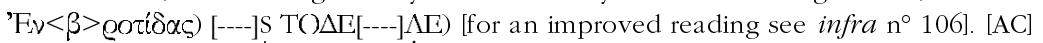

78) A. Johnston, "Notes on Two Inscriptions on Cypriot Statuettes", ZPE 144 (2003), p. 164-166: The inscription on the back of the left leg of the so-called "British Museum Hunter",

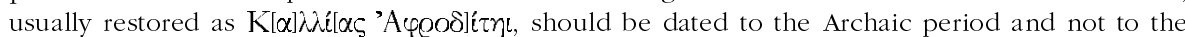
5 th cent. Therefore, statuette and dedicatory inscriptions are contemporaneous. J. questions whether the suggested restoration corresponds to the space available. J. also suggests that the fragmentary graffito on a kriophoros statuette in the Hermitage Museum (from Knidos, Kalymnos, or Asia Minor) could be read as [ $\Delta$ Qlupséo igós, $\Delta$ Qúurç being either a variant of the cult epithet $\triangle$ Quiaios of Apollon in Miletos or the name of a male wood-nymph. [JM]

79) M. KaJaVA, "Eresian Memories", ZPE 139 (2002), p. 89-107 [SEG LII 765, 770-782; cf. $E B G R$ 2002, 71]: K. associates a series of inscriptions of Eresos with the emperor cult, suggesting new restorations. He regards C. Cornelius, son of Zoittas, known as the dedicator of a building to Augustus and the Demos (IG XII.2, 536), as an important promoter of the emperor cult in Eresos was in the early 1 st cent. AD). [The letter forms suggest, however, a date in the 2 nd cent. AD; this text does not necessarily attest a cult of the Demos or the dedication of a temple]. K. identifies C. Cornelius as the anonymous man in $I G$ XII Suppl. 124, who "dedicated to the sons of Augustus a sanctuary and a temple from his own money in the most prominent part of the square", built in the most prominent place of the city "a sanctuary and temple which ... he dedicated to Livia Sebasta Pronoia", "founded at the harbour of the market a temple (or according to K.'s restoration, an altar) to Augustus God Caesar", and "built a temple to Augustus God Caesar" in an unknown place in Asia Minor. He also tentatively attributes to C. Cornelius the dedication of cult buildings (?) for the well-being of Augustus, Caius and Lucius Caesar, and Livia (IG XII.2, 573). [For some problems in these restorations see the comments in SEG LII 781 and 782]. Several honorary inscriptions for Augustus (IG XII.2, $542=$ SEG LII 771), Tiberius and Livia (?, IG XII.2, 539), Germanicus (IG XII.2, 540; SEG LII 775?), and Claudius (IG XII.2, 541) are connected with the activities of Damarchos, son of Leon, priest of Augustus (IG XII.2, 542) and high priest of the emperor cult (IG XII.2, 540); his full title is given in IG XII.2, 541 (according to K.'s restoration): [ $\dot{c}$

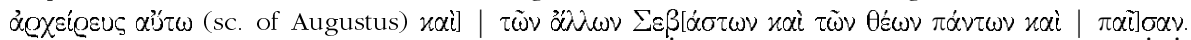
According to K.'s restoration of $I G$ XII.2, 540, Augustus was worshipped as Zeus Caesar Olympios Sebastos. He also identifies the emperor honored with $I G$ XII.2, 545 as Nero and the dedicant as a priest of the emperor cult. He also briefly discusses an honorary inscription from Melos (IG XII.3, 1116; p. 103 note 74), arguing that the honorand was not an ex-priest of Augustus and Tiberius,

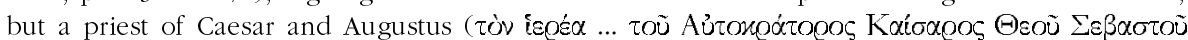

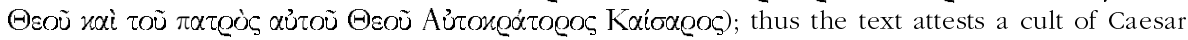

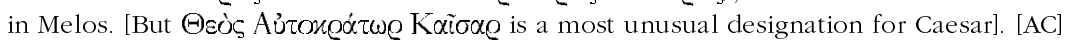

80) M. Kajava, "Inscriptions at Auction", Arctos 37 (2003), p. 69-80: After some general remarks on the habit of recycling statues and inscriptions, $\mathrm{K}$. focuses on a long decree found on the acropolis of Lindos (I.Lindos 419; LSCG Suppl 90, AD 23). As the Lindians had some problems 
in funding their cult activities, they decided to sell during a competitive auction some of the statues ( $\alpha \dot{\alpha} \delta \mathcal{C}(\alpha) \tau \varepsilon)$ standing on the acropolis which were both uninscribed and insignificant

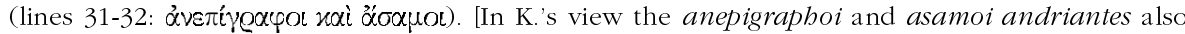
included divine statues. But $\dot{\alpha} v \delta \varrho \alpha \dot{\alpha} \subseteq$ (as opposed to $\not \dot{\alpha} \gamma \alpha \hat{\alpha} \mu \alpha$ ) usually refers to the statues of mortals. The text refers to statues that were not only uninscribed, but also without specific attributes (the opposite of ह̇ioruoc). It follows that no statues of gods were to be sold during this auction]. The money collected during the auction should be part of a fund sacred to Athana Lindia and Zeus Polieus. The verb $\mu \sigma \theta \sigma o ̃ \sigma \theta x i$ (line 34) designates the procedure of becoming the "owner" of the base of an andrias and acquiring in this way the right to inscribe it. This term points to an act of leasing, not of selling. According to $\mathrm{K}$. the decree allowed the lessee of a base to use it (along with the statue on it) until for some unknown reason it would be assigned to a new lessee. [In addition to this, the term $\mu \sigma \theta 0$ vo $\theta x$ made clear to every reader that Athana remained the real owner of the statues, while the person with the highest bid was just the lessee; the inscription also makes a clear distinction between the bronze and iron objects from the nakoreion which were to be sold (lines 21-30), possibly for the recycling of the metal (cf. I. Oropos $324=L S C G 70$ ), and the statue bases which were to be leased out]. The lessees were not allowed to remove the statues from their bases, otherwise they could be accused of impiety, but they could get permission by the Lindians to replace them (lines 40-44). [JM]

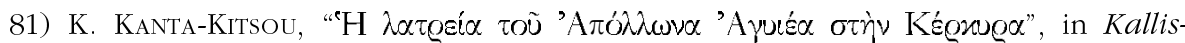
teuma, p. 439-460 [SEG LII 545 quinquies]: K. summarises the evidence for the cults of Kerkyra (p. 442-445) and in particular for the cult of Apollon. She proposes to identify the ancient remains in the area of the monastery of Kassopitra (promontory of Kanoni) with a sanctuary of Apollon Agyieus. Here, a kouros was found in 1992, and in its vicinity a base of a column, interpreted by K. as the base of a 'baetyl', the religious symbol of Apollon Agyieus. Apollon Agyieus must have been worshipped in Korkyra as in other Korinthian colonies. K. adduces as indirect evidence for this cult two inscribed columns (IG IX 1699 and 704). [But see the improved

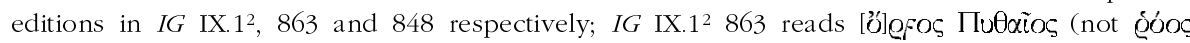
Пu(aios), i.e., the boundary stone of a sanctuary of Apollon Pythaios, and is irrelevant for this question]. [AC]

82) O.E. KAPER, "Review of: A. Hussein, Le sanctuaire de Piyris (Ayn al-Labakha, Oasi de Kharga), Cairo 2000", BiOr 59 (2002), p. 88-93: Ed. pr. of a dedication on a pedestal found in the courtyard of the temple of Piyris ( $2 \mathrm{nd} / 3 \mathrm{rd}$ cent.). [For other inscriptions from this site

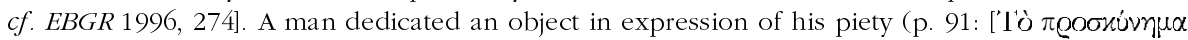

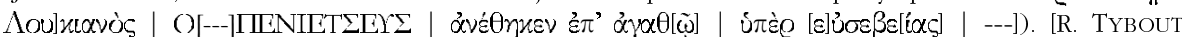

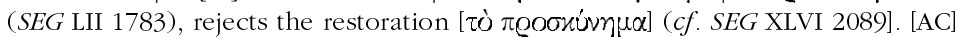

83) C. Karadima-Matsa - N. Dimitrova, "Epitaph for an Initiate at Samothrace and Eleusis", Chiron 33 (2003), p. 335-345 [BE 2004, 247]: Ed. pr. of a grave epigram of unknown provenance (possibly Amphipolis) for Isidoros, son of Nikostratos, from Athens (late

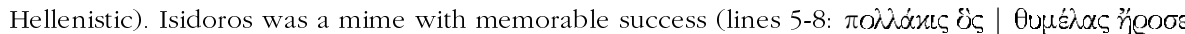

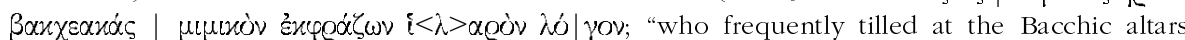
recounting merry speech as a mime"). Isidoros is called $\varepsilon \dot{u} \sigma \Xi ß \dot{c} c$ (line 12) a term recalling the Samothrakian initiates (mysteis eusebeis); he had been initiated in the Mysteries of Samothrake

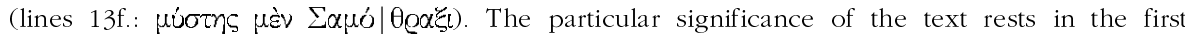
epigraphic attestation of the name Kabiros at Samothrake (line 14). In the epigraphical record the gods of the Samothrakian Mysteries are called Theoi Megaloi, Theoi Samothrakes, or just Theoi,

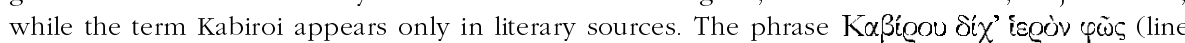
14) is convincingly interpreted by the authors as a poetic manner to say "the sacred light of the two Kabiroi" (not "the doubly sacred light of Kabiros"). While it is well known that viewing sacred light was a central act during the Eleusinian Mysteries, the epigram for Isidoros offers evidence for the same ritual during the Samothrakian Mysteries. Lines 15f. refer to Isidoros'

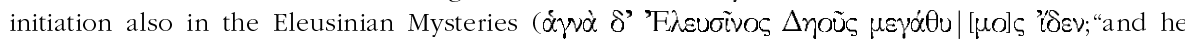
saw [also] the pure rites of Demeter in Eleusis"). The last lines of the epigram demonstrate the interconnection between initiation and blissful afterlife (lines 19-22: $\ddot{\alpha} \lambda \lambda^{\prime}$ 'A 


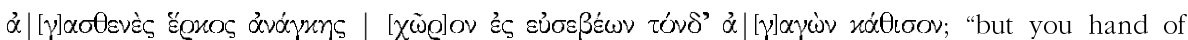
gloomy Hades, extremely powerful bastion of necessity, lead this man to the region of the reverent and place him there"). The authors suggest a semantic connection between $\mu u ́ \sigma \tau \alpha t$

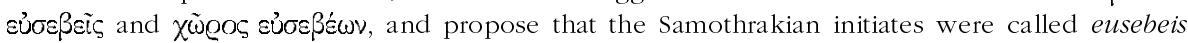
because of their right to be in the place of the pious after death. [JM]

84) I. Karayotov, "Mesambrijskijat panteon", in Jubilaeus V, p. 196-211 (in Bulgarian French summary) [SEG LII 702]: In the light of the epigraphic and numismatic evidence, $\mathrm{K}$. gives an overview of the divinities worshipped in Mesambria (Apollon, Artemis, Asklepios, Athena, Demeter, Dionysos, Hermes, Heros Sosipolis $=$ the Thracian hero Melsa, Hygieia, the Korybantes, Kybele, Nike, Pan, Sarapis, and Zeus) and discusses the cult of personifications (Homonoia, Nemesis, and Tyche) and of the emperor. [AC]

85) R. KaSSEL, "Gesandtschaft nach Ithaka", ZPE 144 (2003), p. 77-78: K. discusses the decree with which Ithaka recognised the asylia of Magnesia on the Maeander and the panhellenic status of the festival of Artemis Leukophryene, and in particular a passage in the narratio (IG

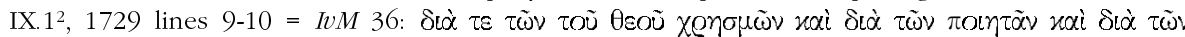

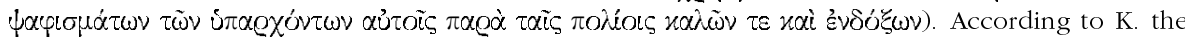
mentioned Delphic oracles were fictitious, the word poets could refer inter alia to Hermesianax, while the psephismata are most probably honorary decrees for Magnesians erected in alien cities, documenting the merits of Magnesians abroad [see already A. CHANIOTIS, Historie und Historiker in den griechischen Inschriften, Stuttgart, 1988, p. 34-37]. [JM]

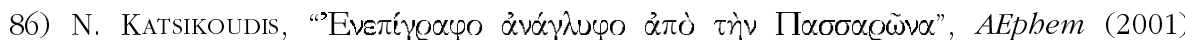
[2003], p. 205-216 [SEG LI 762]: After an iconographical study of a fragmentary relief from Passaron dedicated to Zeus and depicting most probably the god on a wagon drawn by lions (SEG XXXVII 529; XLVII 834), K. concludes that the relief dates to the second half of the 4th cent.

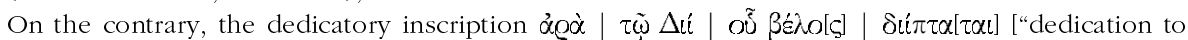
Zeus, whose flying thunder is on its way"] belongs to the end of the 3rd cent. K. suggests that a dedication to Zeus from the 4th cent. was rededicated to Zeus Areios at the end of the 3rd cent., probably in the context of the war between the Aitolians and Philip V (218 BC) [cf. EBGR 1998, 36]. [JM]

87) P. Kiernan, "Did Curse Tablets Work?", in B. Croxford et al. (eds), Proceedings of the Thirteenth Annual Theoretical Roman Archaeology Conference, Leicester, 2003 , p. 123-134: Focusing on British curses that seek the punishment for a thief, $\mathrm{K}$. argues that if the victims of curses knew themselves to have been cursed, this knowledge might have functioned as a traumatic event or an emotional conflict that causes psychosomatic illness. The expected fates of victims of cursing are always plausible elements or real diseases that occasionally have a psychosomatic origin: the defigentes attack the blood of their opponents as a vital fluid; they wish them insomnia, paralysis, weakness of the limbs, an imbalanced gait, reduced motor functions, lethargy, restlessness, loss of memory, blindness, and inability to eat and drink, defecate, urinate, and conceive children. The existence of counter-spells or curses that request the removal of an existing curse suggest that some curse victims did know that they had been cursed. This may have happened in various ways, e.g., by witnessing a loud recitation of the spell or the depositing of the tablets or by being informed by paid professional magicians. Curse tablets may have been displayed or announced prior to their deposition [cf. the practice in Knidos: I.Knidos 147-159]. [AC]

88) T. Korkut - R. Tekoglu, "Grabinschriften aus Pamphylien und Lykien", ZPE 143 (2003), p. 105-116: Ed. pr. and re-edition of epitaphs from Pamphylia, Kilikia, and Lykia. They include three inscribed grave altars, in which the deceased person is designated a hero (1, Patara, 1st cent. AD; 2, Museum of Antalya, 1st cent. BC [rather 1st cent. AD]; 12, Museum of Fethiye, 1st cent. AD). The authors also refer to an epitaph inscribed on a sarcophagus from Deliktas (24, 2nd cent. $\mathrm{AD}$ ), which mentions penalties of unauthorised use of the sarcophagus by persons not belonging to the family [without Greek text or translation]. [JM] 
89) E. Kosmetatou, "Reassessing IG II ${ }^{2}$ 1498-1501A: Kathairesis or Eksetasmos?", Tyche 18 (2003), p. 33-45: K. offers a partially new interpretation of the purpose of a fragmentary decree from the Athenian Akropolis ( $I G \mathrm{II}^{2}$ 1498-1501A, late 4th cent.). The document consisted of two parts: a list of stela $i$ with inventories or accounts issued by the treasurers of Athena and of the Other Gods and a list of dedications and heirlooms. The association of the whole inscription with the activities of Lykourgos on the Akropolis and the general reorganisation of the Attic sanctuaries in the same period is not challenged by K., who suggests that the decree originally listed a large number of objects of different sizes and materials; their only common feature seems to have been most probably their damaged condition. According to K., the decree does not refer to the removal of dedications to be melted down ( $\chi \alpha \theta \alpha i \varrho \varepsilon \sigma \iota)$, but to an inspection of different

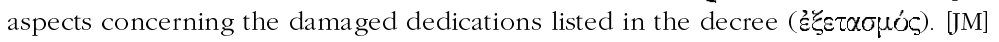

90) N. Kourou, "Tenos - Xobourgo. From a Refuge Place to an Extensive Fortified Settlement", in Excavating Classical Culture, p. 255-268 [SEG LII 803]: K. mentions the discovery of graffiti on vases in a Thesmophorion at Xobourgo on Tenos ( 5 th/4th cent.). The vases are inscribed with the abbreviated theonyms Demeter and Potnia. [AC]

91) S.A. Kovalenko, "Struck Lead Pieces from Tauric Chersonesos: Coins or Tesserae?", NC162 (2002), p. 33-58 [SEG LII 738]: Lead coin-shaped objects found in the Tauric Chersonesos (3rd cent.) had been interpreted as extraordinary coin issues caused by a shortage of copper. An analysis of the iconography, which consists of divinities (Parthenos, Hermes, Athena, Nike), animals (eagle, dolphin, crab, swan), flowers, and objects (bucranium, lyre, cornucopia, star, vessel, tripod, bow, prow) leads $\mathrm{K}$. to the conclusion that these objects were tokens produced at the city mint (catalogue on p. 52-58). The images suggest a connection with civic cults and festivals. These tokens were probably used for the public distribution of food during

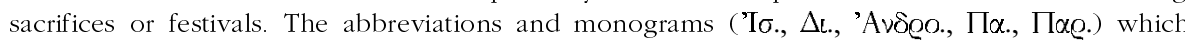
occasionally appear on them may be the abbreviated names of wealthy citizens who had donated money for these distributions, and the abbreviated name of $\Pi x \mathrm{~g}(\theta \hat{\varepsilon} v \mathrm{c} c)$, whose sanctuary also may have funded such distributions. In this context $\mathrm{K}$. discusses the creation of new festivals in the 3 rd cent. and the relation between the iconography of the tokens and local cults. [AC]

92) L. Laugier, De l'Égypte à Pompéi. Le Cabinet d'antiques du duc d'Aumale, Chantilly, 2002 [SEG LII 1789; BE 2003, 624]: Ed. pr. of a small bronze Apis bull (34 n 30, Saqqarah, c. 450-400). After an older hieroglyphic inscription on the front had been erased, the statuette was

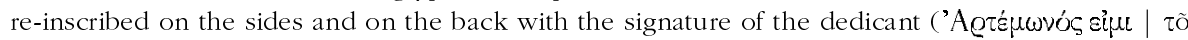
Aúloloc) [as read by J. Bingen, $B E$ 2003, 624, who observes that the dedicant was one of the Hellenomemphites, the worshippers of Osiris-Apis of Memphis]. [AC]

93) F. LeFÈVRE, "Alexandre et l'Amphictionie en 336/5", BCH 126 (2002), p. 73-81 [SEG LII 513; $B E$ 2004, 190]: Brief discussion of the early relations of Alexander the Great and the Delphic Amphictyony immediately after his accession to the throne (336 BC). [AC]

94) P. LIDDEL, "The Places of Publication of Athenian State Decrees from the 5th Century BC to the 3rd Century AD", ZPE 143 (2003), p. $79-93$ [BE 2004, 136]: Overview of the possible locations for the placement of Athenian state decrees. The earliest extant Attic decree $\left(I G \mathrm{I}^{3} 1\right)$ was found on the Akropolis, which was the original and most common location for the publication of decrees. In the periods after 301/300 B.C. a pattern of dispersal away from the Akropolis becomes more and more apparent. One of the reasons for such a tendency could have been the crowdedness of the Akropolis. The Athenian Agora becomes a more popular place for the erection of decrees mainly after the Lykourgan period. Interestingly, the majority of

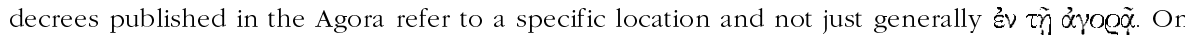
the contrary, in the case of decrees to be published on the Akropolis (¿े $\dot{\alpha} x \varrho 0 \pi \dot{\partial} \lambda \Omega t$ ), no specific location is given; from this L. infers that there must have existed a contextual relationship between the content of the decrees erected in the Agora and their placement. The same interconnection between content and location characterises decrees published in the Amphiareion of Oropos, the sanctuary of Dionysos in Athens, the Athenian Asklepieion, Eleusis, and the city Eleusinion. [JM] 


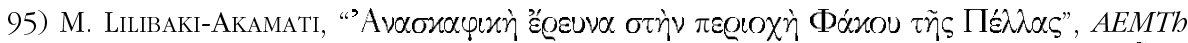
17 (2003), p. 465-483: Ed. pr. of a thanksgiving dedication to Hermes Agoraios (Aữ $\lambda \propto S$

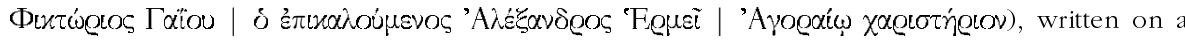
cylindrical marble pedestal, found during rescue excavations in Fakos (near Pella, early 1st cent. BC). [JM]

96) P. Loungarova, "Les cultes du territoire de Nicopolis ad Istrum", in The Roman and Late Roman City, p. 91-98 (in Bulgarian; French summary) [SEG LII 716]: Overview of the cults in Nicopolis ad Istrum, with particular emphasis on the cults of the territory (2nd-3rd cent.). The cults attested include those of Asklepios, Athena, Dionysos, Hermes, Megale Meter, Mithras, Silvanus, Zeus, the Thracian Rider, and the Capitoline Triad. The inscriptions suggest that the worshippers were Romanised Thracians, immigrants from Asia Minor, and veterans. [AC]

97) E. Lupu, "Sacrifice at the Amphiareion and a Fragmentary Sacred Law from Oropos", Hesperia 72 (2003), p. 321-340: L. discusses a fragmentary inscription found in the sanctuary of Amphiaraos at Oropos concerning details of the sacrificial procedure (I.Oropos $278=$ EBGR 1997, 296, 4th cent.). The author recognises a connection between I.Oropos 278, LSCG 69 (= I.Oropos 277, 387-377 BC), and a passage in Pausanias' description of the incubation in the Amphiareion referring to the pre-incubation sacrifice of a ram (PAUS. I, 34, 5). Based on the connection of LSCG 69 lines 25-36 to pre-incubation sacrifice, L. places I.Oropos 278 in the same context. According to his interpretation, at least part of I.Oropos 278 should be seen as a sacrificial tariff. [In LSCG 69 an entire section is devoted to sacrifice (lines 25-36), regulating private and public sacrifices, but L.'s assumption that these regulations refer explicitly to the preincubation sacrifice is highly hypothetical. After a comparison between the literary sources for pre-incubation sacrifices (Pausanias) and iconographical evidence (votive reliefs) L. attributes to the latter an almost illustrative character disregarding the rules that determine the iconography of (votive) reliefs. In addition to this, a comparison between literary sources of the 2 nd cent. AD and reliefs of the 4th cent. BC is methodologically problematic. Although the general interpretation of I.Oropos 278 as a sacrificial tariff remains convincing, the explicit connection with the preincubation sacrifice is problematic]. In a helpful appendix L. presents a selection of sacrificial tariffs prescribing payment for the sacrifice of animals, and a brief commentary [see also E. LuPU, Greek Sacred Law. A Collection of New Documents (NGSL), Leiden, 2005]. [JM]

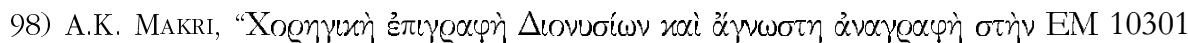
(IG II 23092)", Horos 10-12 (1992-98), p. 61-70 [SEG XLVI 253]: Ed. pr. of a small fragment of a choregic dedication naming the winners in the dithyrambic contest of the city Dionysia (Athens, c. 350 BC). M. observes that the choregic dedication $I G \mathrm{II}^{2} 3092$ (early 4th cent.) is inscribed also on its right side, preserving the names of the choregos and the didaskalos. She suggests that their victory occurred at the rural Dionysia of Acharnai. [AC]

99) H. Malay, "A Praise on Men Artemidorou Axiottenos", $E A 36$ (2003), p. 13-18 [BE

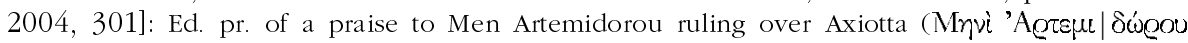

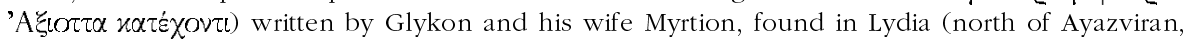
(57/8 AD). Glykon praises Men Artemidorou for punishing his nephew Demainetos, who had arrested and imprisoned him. In line $2 \mathrm{Men}$ is designated as Ouranios, but M. shows convincingly that Ouranios is not a cult epithet. In 1. 8-10 M. interprets the notions of hosion, dikaion, nike and

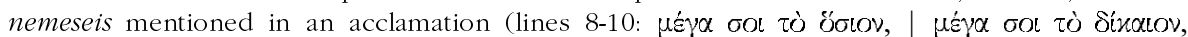

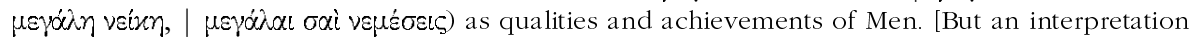
as individual divinities should not be excluded, as a comparison with the acclamation in lines 10-

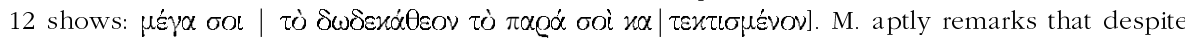
the similarities of this text with proper 'confession inscriptions' it should be separated from them. [JM]

100) H. Malay - G. Petzl, "Posthumous Decree for Philomelos, Son of Ophelas, Issued by the Council and the People of the Mysoi Abaitai", EA 36 (2003), p. 19-22 [BE 2004, 303]: Ed. pr. of a decree (near Silandos, 2nd/1st cent.). Philomelos is honoured posthumously by the council and the people of Mysoi Abaitai inter alia for his piety towards the gods ( $\pi \varrho \dot{c} \varsigma \delta \dot{\varepsilon}$ toù 


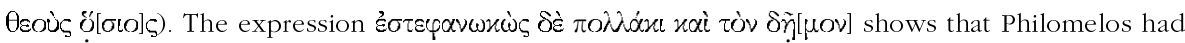
transferred crowns awarded to him (possibly wreaths of victories in contests) to the entire people [cf. the remarks of P. GAUTHIER, BE 2004, 303]. [JM]

101) G. Manganaro, "Delfi, Brindisi e Ancona", ZPE 142 (2003), p. 134-138: Based on two Dephic proxeny decrees of the Hellenistic period M. stresses the religious mobility from the Greek West towards the important sanctuaries of Greece, as this is exemplified by evidence concerning the harbors of Ancona and Brindisi. [JM]

102) G. Manganaro, "Iscrizioni greche del V sec. a.C. della Sicilia", ZPE 144 (2003), p. 147-156: M. offers a new reading of a graffito on a 5 th cent. kotyle found in a grave at

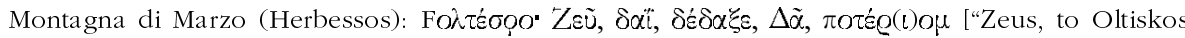
(do I belong); Da, in the contest I taught some lessons, (I) the drink cup"]. An inscription on a tubular terracotta object, most probably the long base of a figurine (late 5 th cent.), records the

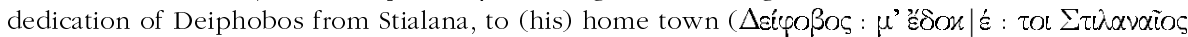

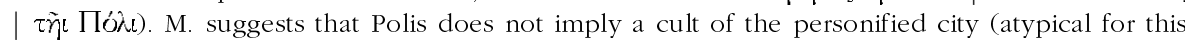
period of time), but perhaps a cult of the eponymous divinity. [JM]

103) G. Manganaro, "Demetra degli Ennaioi", Epigraphica 65 (2003), p. 9-18: M. proposes a new reading of a dedicatory inscription (SEG XIV 598, Enna, 4th/3rd cent.) on a

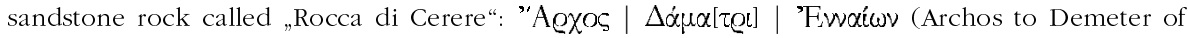

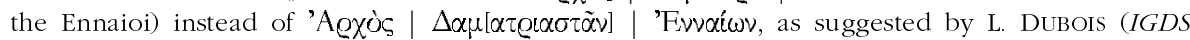
198) [EBGR 1989, 29]. [JM]

104) S.M. Marengo, "L'iscrizione votiva di Claudio Lykos", Quaderni di Archeologia della Libya 18 (2003), p. 205-210: The healing deities Iatros and Iaso are well attested in Kyrenaika (SEG IX 75; XLIII 1189-1191; SECir 165; cf. EBGR 1993/94, 60). One of the known dedications is addressed to Methysis, Minerva, Iatros, and Iaso, called Theoi Epekooi (SECir 165, Balagrai, 2nd/3rd cent.). Minerva/Athena was often associated with healing. The enigmatic worship of Methysis ('drunkeness') in Balagrai may be explained in view of the representation of Methe in the tholos of the Asklepieion of Epidauros (PAUS. II 27, 3). M. tentatively associates Methysis and Methe with the use of wine in healing practices and with the loss of consciousness during incubation. $[\mathrm{AC}]$

105) G. Marginesu, "Due frammenti di iscrizioni vascolari dal santuario sull'Acropoli di Gortina", ZPE 140 (2002), p. 67-70 [SEG LII 861]: Ed. pr. of a graffito on a vase found in the sanctuary on the acropolis of Gortyn (Crete, late 7th cent.). A form of the word $\delta$ É $\sigma \pi \mathrm{s} v \alpha$ may be possibly restored in this fragment ([--]IY[--] | [--]חOIN $\Lambda[--])$. In this case, the later cult of Athena in this sanctuary may have been preceded by the cult of a goddess of fertility. [AC]

106) G. Marginesu, "Lo scudo di Eubolidas", ASAA 81 (2003), p. 351-361 [SEG LII 859]: M. republishes a graffito on a clay miniature shield found in the sanctuary on the acropolis of Gortyn (cf. supra $n^{\circ} 77$ ) on the basis of a photo found in the archive of the Italian Archaeological School (cf. supra $\mathrm{n}^{\circ} 105$ on the dedications in this sanctuary). He reads 'FF $\beta c \lambda i \delta \alpha c$ (sc.

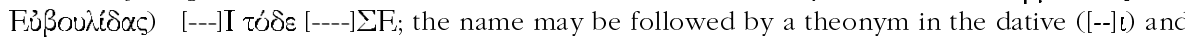

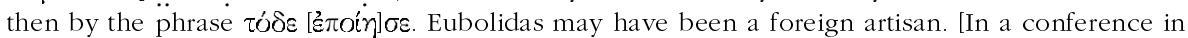
the German Archaeological School in Athens, A. Johnston suggested reading 'Fv $\beta \sigma \lambda \dot{\lambda} \delta \alpha \varsigma=$

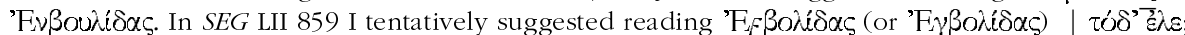

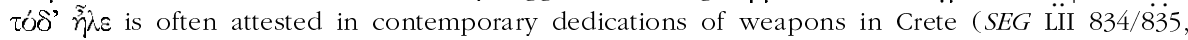
$837 / 838$, and 840); in this case, this is an ironical comment on Eubolidas' failure to capture a real shield: 'this is what Eubolidas was able to capture']. [AC]

107) M. MARI, "Gli studi sul santuario e i culti di Samotracia: prospettive a problemi", in Influenze vicino-orientali, p. 155-167 [SEG LII 809]: Overview of recent research on the cults of Samothrake, including the epigraphic evidence. [For an overview of the mysteries of

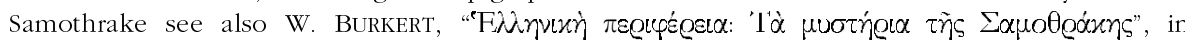
Latreies, p. 31-63]. [AC] 
108) M. MARI, Al di là dell' Olimpo. Macedoni e grandi santuari della Grecia dall'età arcaica al primo ellenismo, Athens/Paris, 2002 [SEG LII 583; BE 2003, 338]: Detailed study of the relations of the Macedonian kings and the Macedonians to the sanctuaries of Delphi, Olympia, Epidauros, Nemea, Isthmia, and Delos, from the Archaic age to Alexander the Great (p. 19-286) with a prosopography of the Macedonians known to have had relations to these sanctuaries as functionaries, recipients of honors, dedicants, artists and scholars, worshippers, victors in contests, and theorodokoi (p. 291-332). [AC]

109) Á. MarTínez Fernández, "Una nueva inscripción votiva de Lisos, Creta", ZPE 145 (2003), p. 131-132 [BE 2004, 254]: Ed. pr. of an inscription on a small gold lamella from the sanctuary of Asklepios at Lisos (3rd/2nd cent.). The inscription documents the dedication of

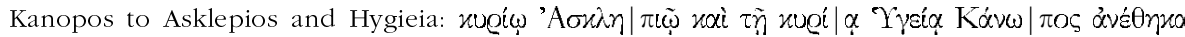

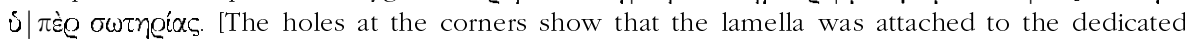
object or at its base]. [JM]

110) M. Melfi, "Il vano del thesauròs nel santuario di Asclepio a Lebena", ASAA 40-42 (1998-2000) [2001], p. 281-314 [SEG LII 872]: M. discusses the room identified as a thesauros (cf. I.Cret. I XVII 6) in the Asklepieion of Lebena (Crete), its mosaic, and its date. A comparison with thesauroi in other cities supports a date of the construction in the first half of the th cent. M. stresses the role of thesauroi in the Asklepieia, but also in the sanctuaries of Apollon, of other healing deities (Amphiaraos, Trophonios), of the Egyptian deities, and in mystery cults (Demeter and Kore, Kabeiroi). This role is connected with the practice of incubation. M. compiled a useful list of the thesauroi in other cities (p. 292-294), with data on their location, their architectural features, and the measures for the security of their content and a list of the archaeological and epigraphic evidence on thesauroi in Asklepieia (p. 301-304). [AC]

111) M. Melfi, "Il complesso del Pythion-Asklepieion a Paro", $A S A A 80$ (2002), p. $327-$ 360 [SEG LII 795; BE 2004, 43]: Detailed study of the archaeological remains of a sanctuary southwest of Paroikia, hitherto attributed to Apollon Pythios and Asklepios. M. argues that the cult of Apollon, practiced here from the second half of the 6th to the 5th cent. ( $c f$. IG XII.5, 147148), cannot have been the cult of Apollon Pythios. A decree that mentions the Pythion (IG XII.5, 110-111) was found at a distance, and it is unlikely that the Pythion, which served as the city's archive ( $c f$. SEG XXXIII 679), was located outside the city. In the 4th cent. Apollon's cult was replaced by that of Asklepios, and the monumentalisation of the Asklepieion started in the later part of the century. The architectural remains belong only to one temple (late 3 rd cent.), dedicated to Asklepios. M. discusses in detail the history of the sanctuary (p. 336-355), its build-

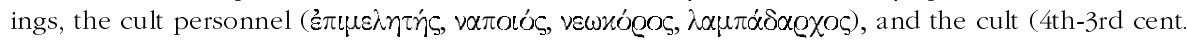
BC and 2nd-3rd cent. AD), in particular the anatomical dedications [cf. EBGR 1996, 86]. In the Imperial period, a new ritual was added to the cult of Asklepios and Hygieia: the consecration of hair locks in the contexts of rituals of the ephebes (p. 350-355) - Asklepios and Hygieia were regarded as patrons of youth (kourotrophoi). M. presents a chronologically arranged catalogue of the inscriptions found in the sanctuary (p. 356f.). [AC]

112) C. Milani, "La madre terra nei nuovi testi micenei di Tebe", Aevum 77 (2003), p. 3-8: M. discusses the theonyms ma-ka, o-po-re-i, and ko-wa in new Linear-B texts from

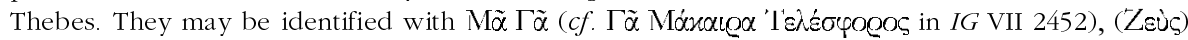
'Orígns (cf. IG VII 2733), and Kógn. The cult of Demeter continued the cult of Mother Earth [cf. EBGR 1997, 155]. [AC]

113) A. MiLČEV, "Nadpis na gracki ezik ot Pliska", in Jubilaeus V, p. 280-284 (in Bulgarian) [SEG LII 724]: Ed. pr. of an important honorary decree for the statesman and benefactor Meniskos (Histria?, c. 200 BC), who saved the city from the danger of war. [We consider here the improved edition by A. Avram in SEG LII 724]. His benefactions included the

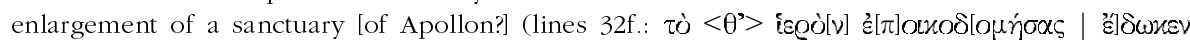
$\alpha \dot{u} \tau \tilde{\omega} ![\tau] \mu \dot{\alpha}(c)$. The stele with the decree was to be erected in the sanctuary of Apollon. Meniskos received 300 gold staters as compensation for the loss of property he had suffered and in order to 


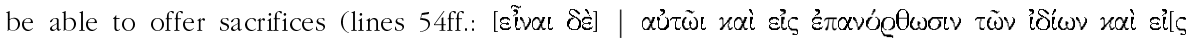

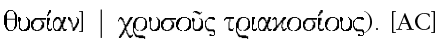

114) S.G. Miller, "Cult Tables from Nemea", in Kallisteuma, p. 461-468 (ph.) [SEG LI 359]: M. studies a particular type of cult tables ('Athenian Tray Design') used as the offering place of the god's share of the meat, presenting two specimens from the sanctuary of Zeus in Nemea. One of them is dedicated to the Epidaurian gods, i.e., Apollon and Asklepios and the Nemean

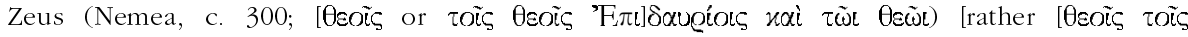
'F $\pi$ ldougiors]. The Athenian origin of this type of cult tables is not certain. [AC]

115) N.P. Milner, "Notes and Inscriptions on the Cult of Apollo at Oinoanda", AS 50 (2000), p. 139-149 [SEG L 1354 bis]: Ed. pr. of two important inscriptions from Oinoanda. The

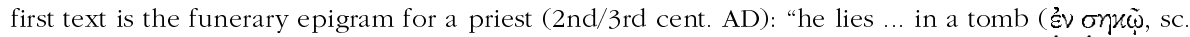
in a heroon) ... [here] beside springs of the Nymphs together with Dionysos; to those praying

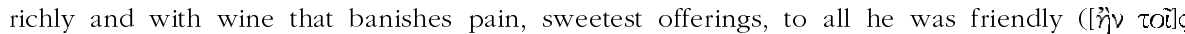

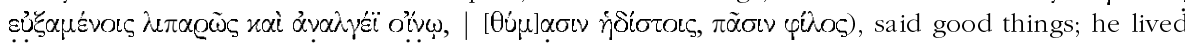
his life flourishingly, in his fine girdle (

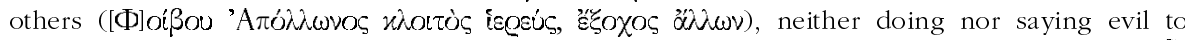

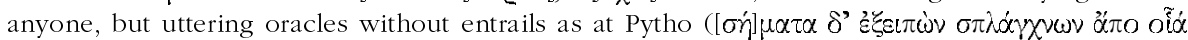
$\tau \varepsilon$ Пu$\theta 0 i \tilde{\imath})$. The priest was buried in a heroon located near a Nympheum; there is a known sanctuary of the Nymphs on the eastern slope just below the city. The sacrifices mentioned by the priest refer to burnt sacrifices of meat, grain, incense, and wine. The $x \alpha \hat{\lambda} \dot{v} \nu \xi_{\omega} \tilde{\mu} \mu \alpha$ refers either to the whole of the sacred vestments or to a particular priestly garb (sacrificial apron?) [to the examples of priestly garments mentioned by $\mathrm{M}$. add the relevant prescriptions in cult regulations collected by A. CHANIOTIS, "Griechische Rituale der Statusänderung und ihre Dynamik", in M. STEINICKE - S. WeINFURTER (eds), Investitur- und Krönungsrituale, Köln/Weimar 2005, p. 50f.]. Apollon's priest did not inspect entrails for signs, but was a prophet who delivered oracles in words ( $\sigma \dot{r} \mu x \tau \alpha)$, inspired by Apollon exactly as the Pythia. M. collects further examples of praises for priests (e.g., SEG XLIV $904=E B G R$ 1993/94, 23; the epitaph of Epitynchanos $=$ supra $\mathrm{n}^{\circ} 71$ ), including Christian priests ( $S E G$ XLV 1701).

The second text is a very fragmentary verse oracle of Apollon (1st cent. BC), which perhaps promises help from Asklepios during a plague: "pronounces ( $\alpha \dot{\delta} \delta \tilde{x})$... the healer of diseases

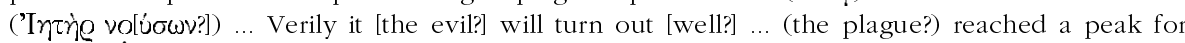
many (people?)... for whom equal to/like these ... of most honoured son as Helper (BotGoũ

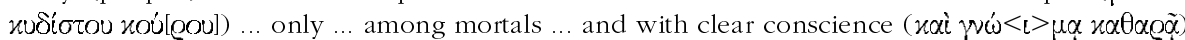

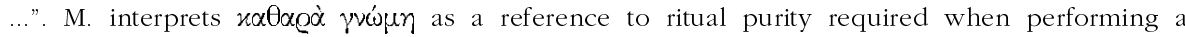
sacrifice [for more evidence see EBGR 1997, 71] and suspects that Apollon instructed the people of Oinoanda to worship Asklepios. A shrine of Asklepios at Oinoanda, later elaborated by the doctor Kapaneus (M. HOlLEAUX - P. PARIs, "Inscriptions d'Oinoanda", BCH 10 [1886], p. 216 n 1), may have been founded as a response to this oracle. [AC]

116) S. Mitchell, "Inscriptions from Melli (Kocaaliler) in Pisidia", AS 53 (2003), p. 139159: Among the new inscriptions found in Melli (Pisidia), the most important text is the basis of a

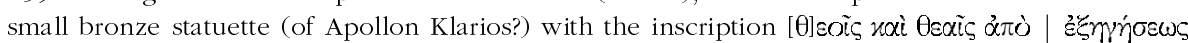

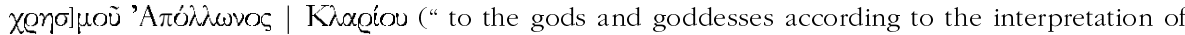
an oracle of Clarian Apollo" (13, second half of the 2 nd cent. AD or later). Latin versions of this text (diis deabusque secundum interpretationem oraculi Clarii Apollinis) are known from various parts of the Empire (Britannia: CIL VII 633; Dalmatia: CIL III 2880; Numidia: CIL VIII 8351; Sardinia: An.Ép. 1929, 156; Italy: An.Ép. 1986, 281; 1991, 564; Mauretania: I.Maroc 344; Hispania Citerior: An.EP. 1990, 545). All the texts may be contemporaneous; Eric Birley attributed them to an initiative of Caracalla, after his consultation of the oracle at Klaros in AD 213. The text from Melli was found in a house that $\mathrm{M}$. interprets as a cult place, originally built for the cult of Theos Hypsistos. He rightly points out the difference of this dedication from dedications made $x \alpha \tau \grave{~}$ xonouciv, since this text refers to the interpretation of an oracle. He suggests identifying this oracle with the theosophical oracle from Oinoanda that explains the nature of god (SEG XXVII 933; EBGR 1998, 164), who is called Theos Hypsistos in another text from Oinoanda. The 
interpretation of this oracle may have recommended continuing the worship of the traditional Olympian gods, although they ranked below the highest god. Thus it reconciled traditional religion with the rising popularity of monotheistic tendencies. It is not clear how the oracle and its interpretation were disseminated, but it is possible that the oracle of Klaros took a lead in sending this message to the Latin-speaking parts of the Empire.

The other texts include a dedication to Zeus Megistos, the other gods of the fatherland ( $\pi \dot{\alpha} \tau \varrho$ lo!

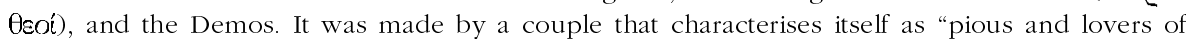

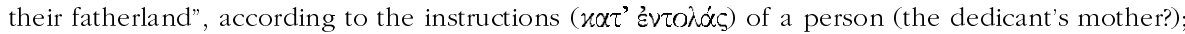
the text is written on the door lintel of a temple or a sanctuary (12, 2nd cent. AD). [For the last

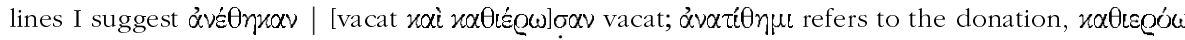
to the rituals of consecration; for this distinction $c f$. SEG XIV 1719; XVLI 1672 B and 1711; for

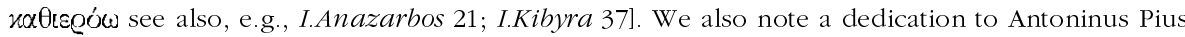
(3) and an epitaph in which the deceased person is called a $\ddot{r} C \omega c$ (15, 3rd cent. AD). [AC]

117) G. Mitrev, "Dionisovite tiasi v rimska provincija Makedonija - tradicii i novovavedenija", in Jubilaeus V, p. 289-297 (in Bulgarian) [SEG LII 586]: Overview of the epigraphic evidence for Dionysiac cult associations in the Roman province of Macedonia ( $c f$. IG X 21244 , 259/260, 309, 503, 506, 666). [AC]

118) H. Müller, "Pergamenische Parerga", Chiron 33 (2003), p. 419-445 [BE 2004, 268]: M. discusses an inscription from Pergamon (IvPergamon 18) in honor of strategoi appointed by

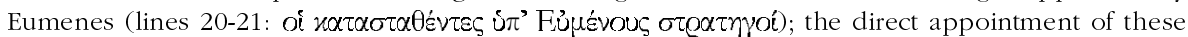
strategoi by the king was a unique instance. The services of these strategoi included the restora-

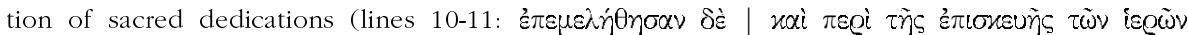

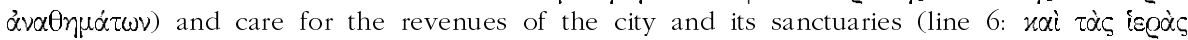
$\pi \varrho c \sigma \delta \delta 0 \cup \varsigma)$. Another inscription from the theater of Pergamon (but originally from the sanctuary of Athena) documents honors for Bito, priestess of Athena Polias (I.Pergamon 223). According to the document, Bito was a priestess during the fourteenth stephanites agon of the Nikephoria,

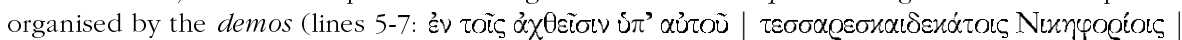

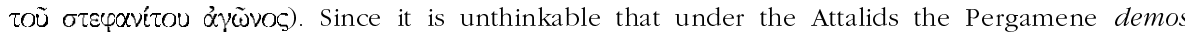
could claim the organisation of the Nikephoria for itself, the inscription must date to a period after the end of the Attalid monarchy. Only if the Nikephoria were a penteteric agon, would such a date for their fourteenth celebration be possible (129 BC). Consequently, this text supports the view of C.P. Jones that the Nikephoria were a penteteric agon, and not a trieteric agon as suggested by D. Musti. [On this controversy see EBGR 1999, 32 and 169; 2000, 90; 2002, 106-197]. [JM]

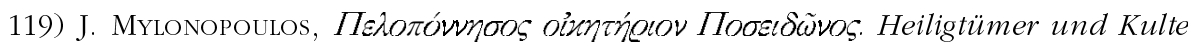
des Poseidon auf der Peloponnes, Liège, 2003 (Kernos, suppl. 13): The first part of the book presents a detailed catalogue of the known cults and cult places of Poseidon on the Peloponnese, adducing and commenting on all the relevant archaeological, literary, epigraphic, and numismatic sources (29-252). On the basis of this material, M. discusses in the second part in a systematic way the various aspects of Poseidon's cult, making extensive use of inscriptions from the Peloponnese and comparanda from other areas. The subjects discussed in this section include the outlook of the sanctuaries (temples, sanctuaries, groves, altars) and their location (agoras, harbors, extra-urban sanctuaries), the cult personnel, the festivals and rituals (in particular sacrifices), the dedicatory practices, the attributes and sacred animals of the god, 28 different epithets, the elements associated with this deity (earthquake, sea, water, horses, underworld), his relation to other divinities, and the political aspects of his cult, in particular his patronage of cities and amphiktyonies. [AC]

120) A.G. Nisoli, "Defixiones politiche e vittime illustri. Il caso della defixio di Focione", Acme 56.3 (2003), p. 271-287: With a defixio as a starting point, addressed against the Athenian statesman Phokion, another seven men, and a woman (DTA 24, mid-4th cent.), N. presents an interesting analysis of curse tablets that mention prominent Athenians, arguing that this evidence shows the practice of magic among the higher strata of society. Eupheros and 
Aristokrates, who were cursed together with Phokion, were brothers of the statesman Kallistratos of Aphidna, who was himself the victim of two other curse tablets (AuDOLLENT, DT 63 and JORDAN, $S G D$ 68); four other men who are mentioned in the same defixio are known for their public activity in Halai, where the tablet was found: Euthemon, Nikomenes, and Astyphilos, who were involved in administrative reforms in Halai ( $c f . I G \mathrm{II}^{2}$ 1174-1175), and Ergokrates. Astyphilos, a prominent public figure $\left(I G \mathrm{II}^{2} 42\right.$ ), is cursed also in another defixio (DTA 47-50), together with his son Menyllos and a certain Philonautes. Philonautes and Astyphilos appear in yet another curse (DTA 57). This evidence shows the interaction among Athenians in a network of political and other relations and confirms the assumption that magical practices were widespread among the higher social strata in Athens. [But these defixiones tell us something only about the status of the victims of curses, not of that of those who applied magic; for a possible exception (Lysias) see infra]. Other defixiones of the second half of the 4 th cent. concern persons involved in the conflict between the friends and the opponents of Macedonia in Athens, including Demosthenes and men associated with him (JORDAN, SGD 48 and DT 60), Lykourgos (DT 60 and SEG XL 269), Hypereides (SEG XL 269), as well as Kassandros, Pleistarchos, Eupolemos, Demetrios of Phaleron, and a man from Piraeus ( SEG XXX $325=$ JORDAN, SGD 13-14). Finally, several tablets concern trierarchs (DTA 103), the victorious generals of the battle at Arginousai (SEG XLIX 314; EBGR 1999, 42), a friend of the general Iphikrates (Diokles: SEG XL 265), and the statesman Aristophon (SEG XXVII 214). The author of a group of defixiones from the Kerameikos may be the famous orator Lysias (SEG XXI 1093). [AC]

121) T. ÖZhan - M. Tombul, "A New Decree of $\tau \dot{c}$ xoıvòv $\tau \tilde{\omega} v \pi \dot{c} \lambda \epsilon \omega \nu$ from Ilion", EA 36 (2003), p. 109-114 [BE 2004, 267]: Ed. pr. of a Hellenistic honorary decree for Antikles, son of Alexandros, from Lampsakos, found near Ilion. The decree is dated by reference to the

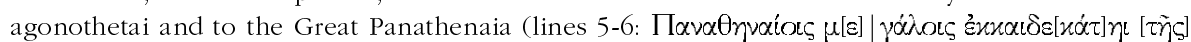

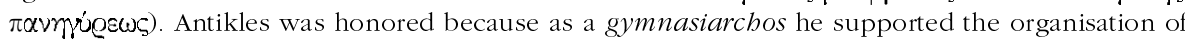
the Small and the Great Panathenaia, upon a request of young men, athletes, and many people who attended the festival that was jointly celebrated by different cities (lines 7-12, 14-24). A

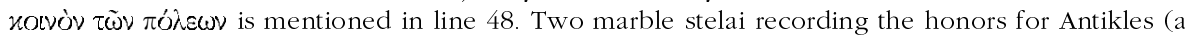
golden wreath and a bronze statue) were to be erected in the sanctuary of Athena at Ilion and in Lampsakos. The synedro $i$ were to send a delegation to Ilion to request the erection of the stele and the statue in the most prominent place in the sanctuary of Athena (lines 56-59). [JM]

122) J.P. Oleson et al., "Preliminary Report of Al-Humayma Excavation Project, 2000

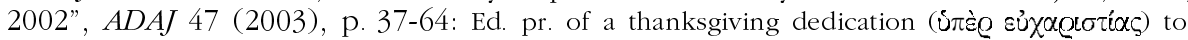
Zeus Sarapis found in a shrine in the Roman vicus of Havarra (Jordan, Imperial period; p. 48). Another dedication by the soldiers of Legio III Cyrenaica Felix is addressed (in Latin) to Jupiter Ammon, pro salute Augustorum (p. 47). [AC]

123) L. Onyshkevych, "Interpreting the Berezan Bone Graffito", in Oikistes, p. 161-179 [SEG LII 731 bis]: An enigmatic text inscribed on a bone (Berezan, c. 525-500; SEG XXXVI 694; $I G D O P$ 93) has been the subject of different interpretations, critically reviewed by O. [cf. EBGR 1987, 32], who presents the text (translation) and a critical review of its previous interpretations (reflection of the demographic development of Olbia, oracle). W. Burkert's interpretation of the text as an oracle $[E B G R$ 1990, 46; 1994/95, 51] is unlikely, since the oracular responses of Didyma did not use the hexameter (Milet I.3, 132 A and 178; Didyma 11), they were introduced by the formula $\theta \varepsilon \dot{c} c$ sĩn $\varepsilon v$, and they concerned laws. O. follows the scholars who have pointed out that

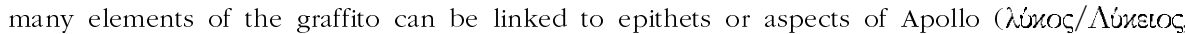

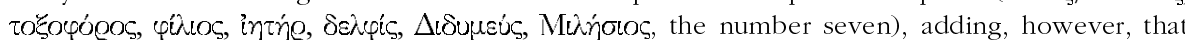
other formulations may be associated with Orphism which is well attested in Olbia. In particular

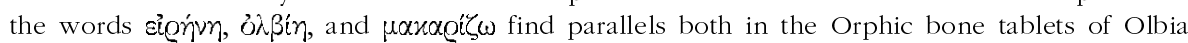
(IGDOP 74; cf. supra $\mathrm{n}^{\circ}$ 6; the opposition peace-war) and in the 'Orphic-Dionysiac' texts

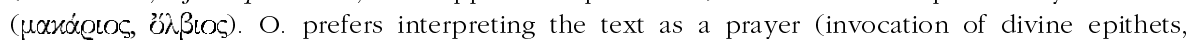
request for peace and happiness) or rather a hymn (epithets, blessings, reference to remembering the deity) [the rhythmical repetition of the number seven and its multiples suggests that the text was meant for oral performance; $c f$. the Orphic lamella from Pelinna (SEG XXXVII 497; EBGR 
1994/95, 148 with further references) and the study of C. Riedweg on the performative context of theses texts (EBGR 1998, 224]. O. does not exclude the possibility of a membership token of a cult group, possibly of a Hebdomadic cult association. [AC]

124) M. Oppermann, "Überlegungen zum Kult des Theos Megas am Westpontos in vorrömischer Zeit”, in Studia Karayotov, p. 50-58 [SEG LII 713]: Overview of the archaeological, numismatic, and epigraphic evidence for the cult of Theos Megas in Moesia (especially in Dionysopolis, Histria, and Odessos), who was associated with Dionysos (with a predominantly chthonic element) and with the Thracian Derzelas/Derzalas . [AC]

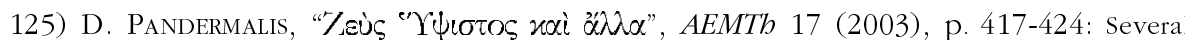
inscriptions referring to the cult of Zeus Hypsistos, the temple, the altar, and perhaps the cult statue of the god were uncovered in Dion in 2003. A small column of green marble bears a

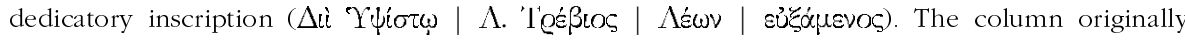
supported an Ionic capital and an eagle found nearby. A marble pedimental crowning is decorated with an eagle flanked by two ears; it was dedicated to Zeus Hypsistos by a former

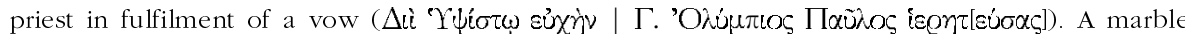

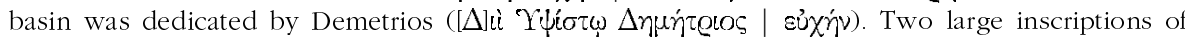
the $3 \mathrm{rd}$ cent. $\mathrm{AD}$ were found in the temple and refer to the persons responsible for the monthly receptions in honor of Zeus Hypsistos and to land belonging to the sanctuary [no text]. Four more inscriptions were found in the cella: a dedication to Jupiter Optimus Maximus, a dedication to Zeus Hypsistos, and two inscriptions referring to donations of stoai to the sanctuary [no texts]). [JM]

126) M.-G. Parissaki, "Mandra, Abdère et Thasos. Remarques sur deux inscriptions errantes", Tekmeria 7 (2002), p. 107-115: [SEG LII 816]: P. demonstrates that an altar dedicated to Isis and Sarapis found in Mandra, near Abdera (BE 1975, 463; 1st cent. BC), is in fact

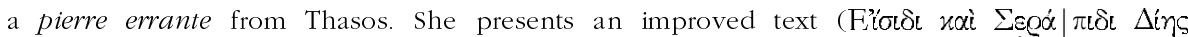
Fủ| 'qCîinou |---]). [AC]

127) O. Peleg, "Roman Marble Sculpture from the Temple Mount Excavations", in A. Faust - E. Baruch (eds), New Studies on Jerusalem. Proceedings of the Seventh Conference, December 6th 2001, Ramat-Gan, 2001, p. 129-150: Ed. pr. of a dedication inscribed on the base of a female statue (of a goddess?; Jerusalem, Imperial period; p. 130). A woman dedicated the statue in fulfilment of a promise (ž $\dot{\varepsilon} \pi 0 \sigma \chi \varepsilon \delta \sigma \omega c$ ) [reading corrected by H.W. PLEKET in SEG LI 2024]. [AC]

128) J.-L. Perpillou, “Animaux d'un an”, $R P h 71$ (2002), p. 233-241: The adjective

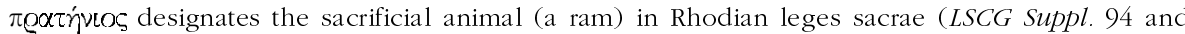
104). Based on these texts and on the few literary sources (Photius, Lexicon p. 115 ed. Naber;

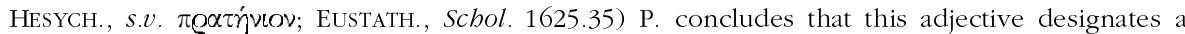

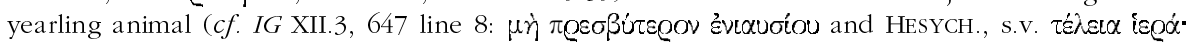

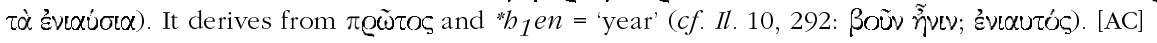

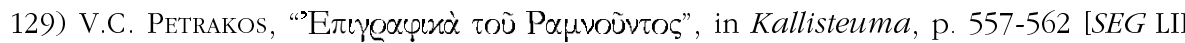
125]: P. presents an improved edition of an honorary decree for general Archandros (Rhamnous, 244 BC?); the joint sacrifice mentioned in the narratio (line 15: [---] $\tau \tilde{r} \zeta$ xovvr̃ $\varsigma$ Avoixc) may be a reference to his service to the paroikoi who served in the fort of Rhamnous. P. also republishes the honorary decree SEG XLI 91 [EBGR 1991, 183] which was set up in the sanctuary of Aphrodite Hegemone (lines 8-9; Rhamnous, c. 221 BC). [AC]

130) V. Petrakos, "Meooŕvr", Ergon (2003), p. 30-47: P. reports the discovery of new inscriptions in Messene. The inscribed limestone base of the central akroterion of the temple of Zeus Soter was found in his sanctuary. According to the inscription Damophon and his sons made the akroteria of the temple and dedicated them to Zeus, all the gods, and to the city

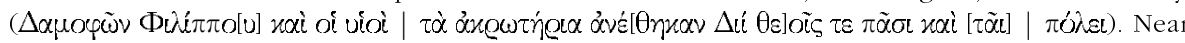
the remains of a Roman villa southeast of the Asklepieion the inscribed capital of a statue base 
was found [no text]: a woman dedicated statues of her three grandchildren to Eileithyia and all the gods. [JM]

131) M. Piérart, "Argos, Philippe II et la Cynourie (Thyréatide) : les frontièrs du partage des Héraclides", in R. FREI-STOLBA - K. GEX (eds), Recherches récentes sur le monde bellénistique. Actes du colloque organisé à l'occasion du 60 anniversaire de Pierre Ducrey, Lausanne, 20-21 novembre 1998, Bern 2001, p. 27-43 [SEG LI 424]: Ed. pr. of a block of an altar (Xeropigadi in Kynouria, c. 475-425; p. 29); two legs in relief are

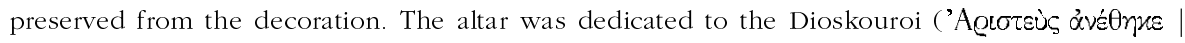
Favxuciv). [AC]

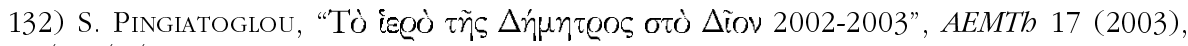
p. 425-434: Inscriptions have identified a sanctuary excavated in 1973 in Dion (Macedonia) as an Asklepieion. The author excavated a sanctuary of Demeter in its direct vicinity. On the basis of literary sources and inscriptions from other parts of Greece, P. attempts to explain the remarkable proximity of the Asklepieion and to the sanctuary of Demeter. [JM]

133) V. Pirenne-Delforge, "La genèse de l'Aphrodite grecque : le 'dossier crétois", in Influenze vicino-orientali, p. 169-187 [SEG LII 825]: In a study of the possible influence of the nature of the cult of Aphrodite from the Near East, P. gives an overview of the cult of Aphrodite on Crete (p. 172-175) and her relation to male rites of passage. An analysis of the elements of nakedness (175-181) and sexuality (181-186) in early literary sources and images suggests that the figure of Aphrodite developed gradually in the beginning of the first Millennium under the influence of an Oriental divinity such as Astarte. [See now also V. KARAGEORGHIS, "H

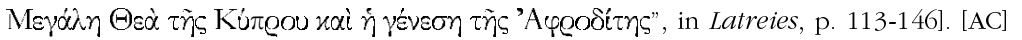

134) E. PÖHLmann - M. West, Documents of Ancient Greek Music: The Extant Melodies and Fragments edited and transcribed with comments, Oxford, 2001: The commented edition of fragments of literary texts accompanied with signs of musical notation includes, in addition to papyri fragments primarily from drama, also the following religious texts inscribed on stone: the Epidaurian hymn to Asklepios (19 = SEG XXX 390, Hellenistic), the Delphic paians of Athenaios and Limenios (20-21 = F.Delphes III 2 137-138; CID III 1-2, late 2nd cent.) [cf. EBGR 2001, 12 and 62], a very fragmentary hymn to Sinuri from Mylasa (22 = L. ROBERT, Le sanctuaire de Sinuri près de Mylasa, Paris, 1945, $\mathrm{n}^{\circ}$ 81, 1st cent.). Various hymns of Mesomedes (24-31, 2nd cent. AD), including his hymns to Helios (27) and Nemesis (28), were transmitted through the literary tradition. A papyrus in Berlin $(50=$ Pap.Berlin $6870+14097,2 \mathrm{nd} / 3 \mathrm{rd}$ cent. $)$ preserves a paian. $[\mathrm{AC}]$

135) R. L. Pounder - N. Dimitrova, "Dedication by the Thessalian League to the Great Gods on Samothrace", Hesperia 72 (2003), p. 31-39 [BE 2004, 205, 246]: Ed. pr. of an inscription found in the sanctuary of the Great Gods in Samothrace. The inscription records a dedication of the Thessalian koinon brought to the sanctuary by theoroi (c. 170-140). After the

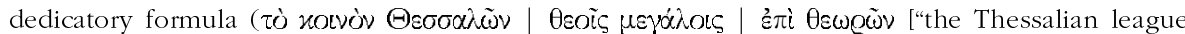
(dedicates this) to the Great Gods during the theoria of"], the names of the four theoroi are given (two from Pherai and two from Larissa) and the date according to the Samothrakian eponymous basileus). The exact purpose and context of such a theoria remains unclear, but this document allows us to include Pherai and Larissa (Thessalian koinon) to the cities which sent sacred ambassadors to Samothrace. [JM]

136) C. Pretre et al., Nouveau choix d'inscriptions de Délos. Lois, comptes et inventaires, Paris, 2002 [SEG LII 753; BE 2003, 396]: Selection of 12 Delian inscriptions (Greek text, French translation, exhaustive commentaries) that provide information on the economy of Delos and the administration and the finances of the sanctuary. The documents are an Athenian administrative document ( $I G \mathrm{I}^{3} 402$, 434-433 BC); an act of the amphyktyones ( $I G \mathrm{II}^{2} 1635+$ add., 377/6-274/3); inventories (I.Délos 104, 364/3; IG IX.2, $287 \mathrm{~B}, 250 \mathrm{BC}$ ); a building contract (IG $\mathrm{II}^{2}$ 1678, c. $350 \mathrm{BC}$ ); an account concerning building works (I.Délos 104-24 + SEG LI 1001, 345/4); accounts of the hieropoioi (IG IX.2, $161 \mathrm{~A}$ and $287 \mathrm{~A}$; I.Délos $399 \mathrm{~A}$ and $442 \mathrm{~A}$, 3rd-2nd cent.); a law concerning the sale of timber and charcoal (I.Délos 509); and an account and leasing 
contracts of the period of the Athenian domination (I.Délos 1417, 156/5). Among the introductory chapters we single out the discussion of the different types of documents and their authors by $\mathrm{V}$. CHANKOwski (p. 15f.). The commentaries address inter alia issues relevant to the administration of the sanctuary of Apollo in Delos, its financial transactions, the artisans in the service of the sanctuary, the inventories, the religious life and the topography of Delos. A series of chapters address a variety of subjects, including the inventories, the administration of the offerings, and the contribution of the inventories to the history of Delos (by C. PRETRE; p. 243-247), the sacred property of Apollo and the economic role of the sacred property during the period of Delian independence (by M. BRUNET; p. 250-255 and 255-258), the debtors and leasers of the sanctuary (by C. Vial and M. BruneT; p. 258-264), and the artisans (by C. FEYEL; p. 264-269). The volume includes a useful glossary of religious terms and types of offerings. [Cf. P. GAUTHIER, BE 2003,

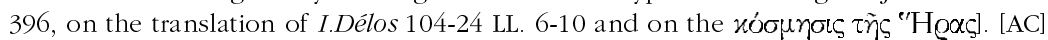

137) W.K. Pritchett, Athenian Calendars and Ekklesias, Amsterdam, 2001 [SEG LI 8]: This study of the Athenian calendar and its complex problems includes also a study of irregularities in the festival calendar (p. 1-40). [AC]

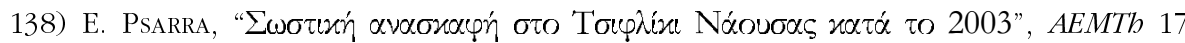
(2003), p. 539-551: During a rescue excavation near the modern city of Naoussa, parts of the narthex of a small basilica with ancient spolia were uncovered. The spolia include a very unusual dedication to Poseidon (2nd cent. AD): a woman dedicated a small relief depicting male genitals

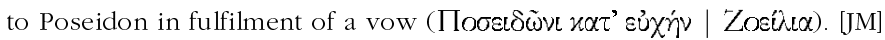

139) G. Pugliese Carratelli, "Il Serapeo di Leptis Magna: Le iscrizioni greche", $Q A L 18$ (2003), p. 271-285 [BE 2004, 459]: PC publishes 15 dedications (pillars, bases, altars) found in the temple of Sarapis in Leptis Magna [for the Latin texts see supra $\mathrm{n}^{\circ}$ 43]; most of them are inedita $(3=\operatorname{IRT} 310 \mathrm{a} ; 7-9=\operatorname{IRT} 311-313 ; 12=\operatorname{IRT} 310 ; 13 \mathrm{~b}=\operatorname{IRT} 559)$. The temple was built during the reign of Antoninus Pius. The majority of the dedicants were Greeks from Egypt. The

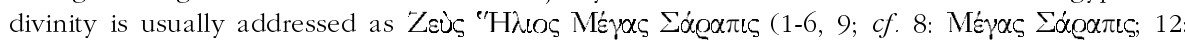

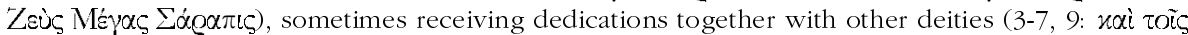

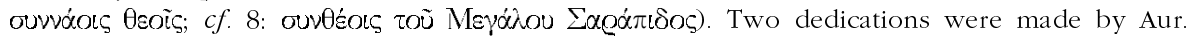
Dioskoros and members of his family, one of them after Dioskoros had been saved from severe

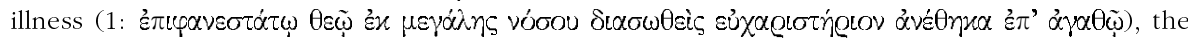

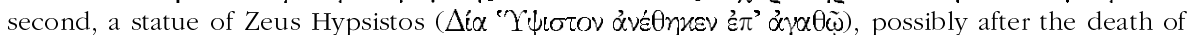

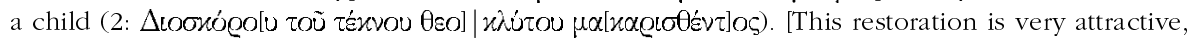

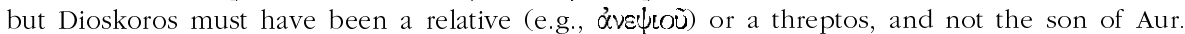
Dioskoros, since a son by this name appears among the dedicants (unless Dioskoros, son of Dioskoros, had two homonymous sons]; two fragments belonging to the same inscriptions are

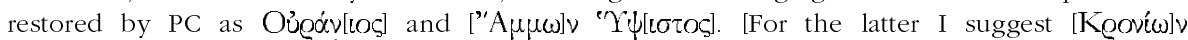

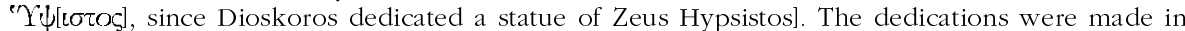

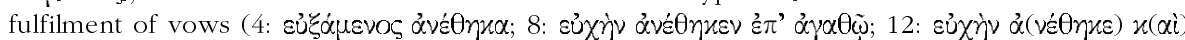

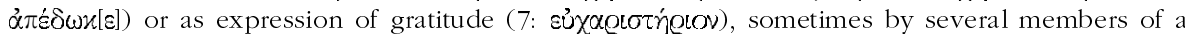

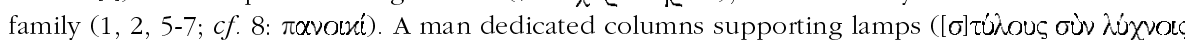
$\delta$ uot) on behalf of a group (association?; 12: $\dot{x} \pi \dot{c}$ xotvavíxc). Three persons are known to have made more than one dedication (Dioskoros: 1-2; Origenes: 5-7; Attalos: 8-9). Three dedications (of statues?) were made in honour of the poet Aurelius Sempronius Serenus Delcitius (13-15; in

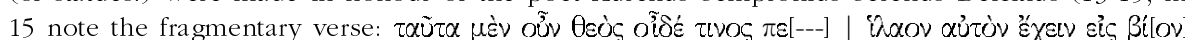
$\varepsilon \dot{b} \xi \alpha \mu[\varepsilon \vee---])$. On two small fragments [certainly of an epigram] one recognises the words

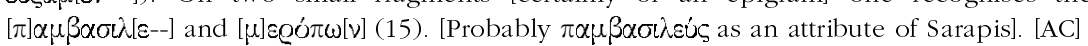

140) K. Reber, "Die Südgrenze des Territoriums von Eretria (Euböa)", $A K 45$ (2002), p. 40-53 [SEG LII 821]: R. shows that a rock-cut inscription in the area of Styra (Metsifi, Euboia), originally interpreted as a boundary stone of a sanctuary of Leto (N.K. MOUTSOPOULOS, "l' $\alpha$

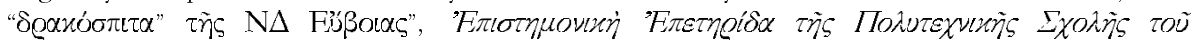

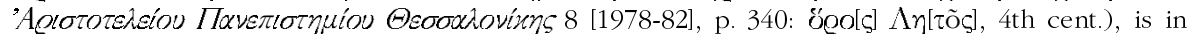
fact a boundary stone of the Eretrian demos of Styra (\&̈oo[c] $\delta \dot{r}[\mu \circ u])$. [AC] 
141) M. RicL, "Society and Economy of Rural Sanctuaries in Roman Lydia and Phrygia", EA 35 (2003), p. 77-101 [BE 2004, 297]: Based almost exclusively on the epigraphic material R. discusses different aspects of rural sanctuaries in Lydia and Phrygia during the Imperial Period:

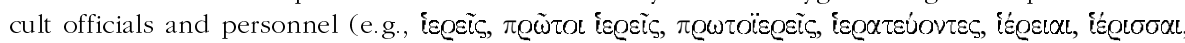

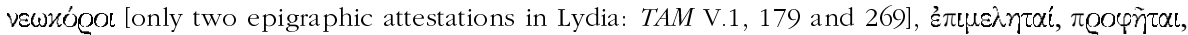

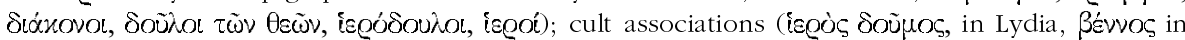
Phrygia, as, e.g., in $S E G$ XL 1221); sacred property (arable land, woods and groves, vineyards, uncultivated plots, houses or parts of houses, cash); temple jurisdiction [ $c f$. also A. CHANIOTIS, "Tempeljustiz im kaiserzeitlichen Kleinasien: Rechtliche Aspekte der Beichtinschriften", in G. THÜR - J. VÉlissaropoulos-KaraKostas (eds.), Symposion 1995. Vorträge zur griechischen und hellenistischen Rechtsgeschichte, Korfu, 1.-5. September 1995, Köln-Weimar-Wien 1997, p. 353-384; id., "Under the Watchful Eyes of the Gods: Aspects of Divine Justice in Hellenistic and Roman Asia Minor", in S. Colvin (ed.), The Greco-Roman East. Politics, Culture, Society, Cambridge, 2004 (Yale Classical Studies 31), p. 1-43]. [JM]

142) M. RicL, "Varia Epigraphica", EA 35 (2003), p. 102-112 [BE 2004, 92 and 304]: Based on different interpretations of syntax and grammar R. offers a new translation of SEG XLVII 1654 (99 AD): "In the year 183, on Pereitios 18. Meis ex Attalou, having punished his own people, (declares) about his own possessions, that no one be allowed to sell or mortgage them, but to provide for himself from his own possessions, and what he desires let him come from his own means. If someone disobeys without his (the god's) permission, he will make restitution from his own funds and appease him (the god) and Meis Labanas." R. also presents a plausible reading of

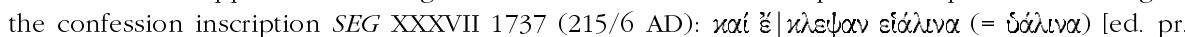

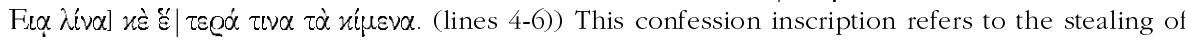
glass objects and other unspecified items from the Lydian sanctuary of Apollon Axyros by Melite and Makedon. In another Lydian confession inscription (BIWK 79), referring to a conflict between

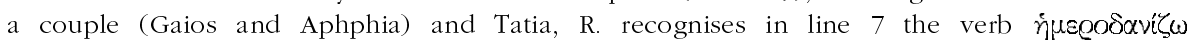
$(\dot{r} \mu \varepsilon \varrho 0 v \delta \alpha\{v\}\{\zeta \omega$, lending on daily interest). Apparently Gaios and Aphphia defrauded their creditor Tatia. Finally, R. offers a new restoration of the first two lines of a dedication to Meter Andeirene found near the village of Eldes (I.Sultan Dagi 404): [Y $\Upsilon$ ]

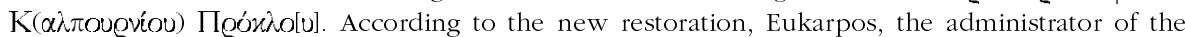
property of L. Calpurnius Proculus, made this dedication to Meter Andeirene for the well-being of his master. [JM]

143) K.J. Rigsby, “Chrysogone's Mother", MH 60 (2003), p. 60-64 [BE 2004, 324]: R. republishes a dedicatory epigram from Knidos (I.Knidos $131=S G O$ I 01/01/06; late th cent.) which reports the dedication of a shrine and a statue to Kore and Demeter by Chrysina after a

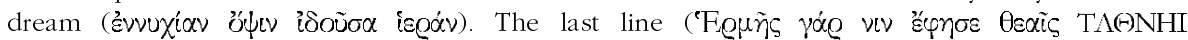
$\pi \varrho C \pi 0 \lambda \varepsilon u ́ \varepsilon I v)$ is taken to refer to Chrysina's vocation to a priesthood ( $c f . I G \mathrm{II}^{2}$ 4969). However, the fact that she introduces herself as 'Chrysogone's mother', and the common meaning of cru' ('say', rather than 'command') suggest that this line does not refer to the dedicant, but to her dead daughter: "for Hermes told (her) that she (Chrysogone) is an attendant to the dread (?) goddess $\left(\theta \Xi \tilde{\alpha} \iota \sigma^{<} \varepsilon \mu>\nu \tilde{r} \mathrm{l}\right)$ )" (for the attribute $\sigma \Xi \mu \nu \dot{\eta}^{\prime}$ in connection with Kore/Persephone $c f$. IG XII 5, 655; Bernand, I.Métr.Eg. 43) Hermes, messenger of Persephone (cf. IG XIV 769), appeared in Chrysina's dream and consoled her by informing her about her daughter's fate in the underworld.

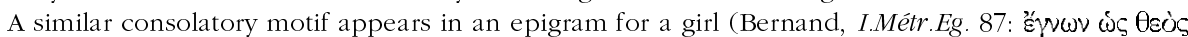

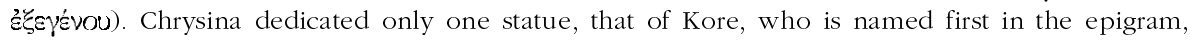
but also Demeter, whose loss, grief, consolation, and honor Chrysina understood. [AC]

144) T. RitTi, "Antonino Pio, 'padrone della terra e del mare'. Una nuova iscrizione onoraria da Hierapolis di Frigia", Annali di Archeologie e di Storia Antica 9/19 (2002/ 2003) [2003], p. 271-282: Ed. pr. of an honorary inscription for Antoninus Pius, who is called

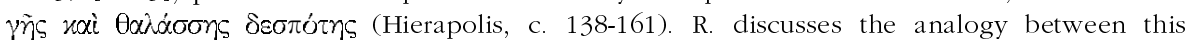
expression, used in connection with the Roman emperor, and the perception of divinities as

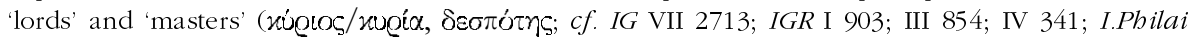

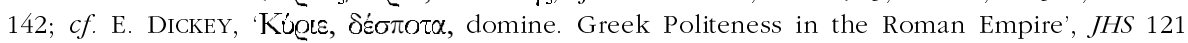


[2001], p. 1-11) [on this subject see now N. BelAYCHE, “'Au(x) dieu(x) qui règne(nt) sur ...' Basileia divine et fonctionnement du polythéisme dans l'Anatolie Impériale", in A. VIGOURT et al. [eds], Pouvoir et religion dans le monde romain. En hommage à Jean-Pierre Martin, Paris, 2006, p. $257-$ 269]. In Hierapolis itself, a new inscription (F. D'ANDRIA, "The Evolution of Hierapolis in Phrygia", in D. PARRISH [ed.], Urbanism in Western Asia Minor, Portsmouth, 2001, p. 23) designates Sarapis

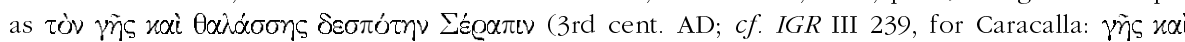

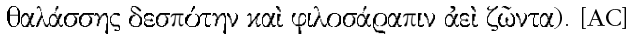

145) D. Rousset, Le territoire de Delphes et la terre d'Apollon, Paris, 2002 [SEG LII 519; $B E$ 2003, 336]: R. presents an excellent study of the historical topography of Delphi and the adjacent areas, the development of the territory of the city of Delphi, and the development of the sacred land of Apollon's sanctuary from the Archaic to the Roman Imperial period. In this context he presents critical editions of inscriptions that concern the delimitations of the territory of Delphi and of the sacred land (p. 71-115), followed by a detailed discussion of the relevant topographical, historical, and legal issues. Drawing primarily upon the relevant inscriptions, R. discusses the notion, origins, and use of the i $\varepsilon 0 \dot{\alpha} \chi \omega \hat{0} \alpha$ of Apollon (183-217), the regulations concerning the use of the sacred land (188-192), the existence of livestock belonging to the god (192-205), and the exploitation of the sacred land (205-211), and the responsibilities of the city of Delphi in the administration of the estates belonging to Apollon (p. 250-282). This is a major contribution to the study of the administration and the finances of Apollon's sanctuary [cf. infra $\mathrm{n}^{\circ}$ 146]. [AC]

140) D. Rousset, "Terres sacrées, terres publiques et terres privées à Delphes", CRAI (2002), p. 215-241: R. presents a useful overview of the extension, development, and use of the sacred land of the sanctuary of Apollon in Delphi [cf. supra ${ }^{\circ}{ }^{145}$ ]. [AC]

147) J. Roy, “The Arkadians in Inschriften von Magnesia 38”, ZPE 145 (2003), p. 123130 [BE 2004, 291]: IvMagnesia 38 is a text inscribed by the officials of Magnesia on the Maeander in the late 3rd cent. and documenting the decision of an Arkadian city to recognise the panhellenic status of the festival in honor of Artemis Leukophryene and the asylia of the city of Magnesia. Appended to this decree are the names of eighteen more cities described as "the other Arkadians". While this decree has been attributed to Megalopolis, R. argues in favor of an attribution to Mantineia. The 'other Arkadians' do not represent a political or institutional unit in Arkadia in the late 3rd cent., but just a grouping made by the Magnesian theoro $i$, who visited the Arkadian poleis, or by the secretary. [JM]

148) A.S. Rusyaeva, "The Temple of Achilles on the Island of Leuke in the Black Sea", ACSS 9.1 (2003), p. 1-16: The literary and archaeological sources allow the assumption that from the late 6th cent. $\mathrm{BC}$ to the $3 \mathrm{rd}$ cent. $\mathrm{AD}$ an Ionic temple of Achilles stood on the island of Leuke (near Olbia); the temple housed a xoanon, a treasury, and an oracle. It is possible that the construction of the temple was a joint project of the Milesian colonies of the Black Sea. In the late 5 th cent. the equestrian statue of a citizen of Olbia (IOSPE $\mathrm{I}^{2} 325$ ) was set up in the sanctuary, and a statue of Achilles was dedicated in or near the temple (IOSPE $\mathrm{I}^{2} 326$ ). R. assumes the existence of a second temple constructed in the 4th cent. [AC]

149) M.C.. SAHIN, "A Hellenistic Decree of the Chrysaoric Confederation from Lagina", EA 35 (2003), p. 1-7 [BE 2004, 309]: During the 1999 excavations near and under the temple of Hekate at Lagina more than 80 fragments of a Hellenistic decree were found (early 2nd cent.). S. presents the Greek text ( 71 lines) and some critical notes without translation. The inscription refers to honors presented to the Stratonikeian Ar[isto]nidas, son of Aristeides, by the Chrysaoric Confederation. Aristonidas was awarded a golden crown and the prohedria during the athletic competitions; his bronze statue was to be erected in the most prominent place of the sanctuary of Zeus Chrysaoreus. The hieromnemones were responsible for the presentation of the golden crown and the bronze statue (lines 65f.). [See the remarks of P. GAUTHIER and C. HABICHT in $B E$ 2004, 309, who point out that the proclamation of the honors took place during the festival of

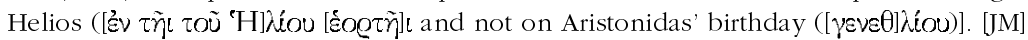

150) G. SAlapata, "Myth into Cult: Alexandra/Kassandra in Lakonia”, in M. Molin (ed.), Images et représentations du pouvoir et de l'ordre social dans l'Antiquité, Paris, 2001, 
p. 131-159: An honorary decree from Amyklai (IG V.1, 26, 2nd/1st cent.) refers to the following honors: "to make also for them a portion of the prostropa on each occasion...; and let also those appointed publish a stone stele on which the decree will be written and set up in the sanctuary of Alexandra." Alexandra/Kassandra is represented in relief holding a kithara, which highlights her association with Apollon and her prophetic abilities. Prostropa (cf. prostropaios $=$ avenger) must have been an expiatory ceremony connected with the tradition of Kassandra's violent death. Kassandra's untimely, violent, and wrongful death may have given the impetus for her heroic worship. In addition to the prostropa, the rituals at Amyklai must have included banqueting and possibly theoxenia. S. argues that Alexandra/Kassandra was not a degraded divinity, but received from the beginning a heroic cult together with Agamemnon at Amyklai, where their graves were shown. Their cult is attested through inscribed clay relief plaques (6th-4th cent.) and continued uninterrupted until the 2nd cent. AD (cf. SEG XXIV 281 and PAUS. III 19, 6); during the Hellenistic period the emphasis shifted from the joint cult to that cult of Kassandra, possibly as a result of territorial developments and the influence of Spartan women. [AC]

151) A. Scholtz, "Aphrodite Pandemos at Naukratis", GRBS 43 (2002/2003), p. 231-242 [SEG LII 1793]: The epithet Pandemos, epigraphically attested for Aphrodite in late Archaic dedications in Naukratis (E.A. GARDNER, Naukratis II, London, 1888, p. $66 \mathrm{n}^{\mathrm{os}} 818$ and 821; D.G. EDGAR, "The Inscribed and Painted Pottery", ABSA 5 [1898/1899], p. $56 \mathrm{n}^{\circ}$ 107) cannot refer to Aphrodite's function as patron of civic unity, since Naukratis acquired the status of a polis later. $\mathrm{S}$. associates this epithet with the goddess' role as protector of seafarers, a goddess 'common to all' - a connection with prostitution should not be excluded. [AC]

152) C. Schuler, "Ein Priestertum der Artemis in Arykanda", Chiron 33 (2003), p. 485504 [BE 2004, 338]: After a thorough discussion of a late Hellenistic inscription from Arykanda in Lykia (I.Arykanda 2), S. presents a new reading of the text, interpreting this inscription as a document regulating the purchase of the priesthood of Artemis at Arykanda. The first two lines apparently belong to a longer part (mostly lost) concerning fines if the purchaser of the priesthood did somebody injustice. The whole amount was to be paid immediately. Lines 4-6 identify the purchaser of the priesthood: Kouava, daughter of Erma[---], and her legal representative, her son Pigres, bought the priesthood for 216 silver drachmas. The publication of the purchase is the subject of lines 7-15. The tamiai were obliged to put a copy of the diagraphe on the anta of the temple of Artemis; if they disregard this duty, they had to pay a fine of 100 silver drachmas to Artemis. [JM]

153) C. SChuler, "Neue Inschriften aus Kyaneai und Umgebung V. Eine Landgemeinde auf dem Territorium von Phellos?", in F. KolB (ed.), Lykische Studien 6. Feldforschungen auf dem Gebiet der Polis Kyaneai in Zentrallykien. Bericht über die Ergebnisse der Kampagnen 1996 und 1997, Bonn, 2003 (Asia Minor Studien, 48), p. 163-186 [BE 2004, 336]: Ed. pr. of 8 inscriptions found at Cardakl1, which S. assigns to the territory of Phellos. The most important text, written on a column, is a fragmentary list of (12 or 13) priests of Zeus which documents the donations they had made for the celebration of a festival (2nd cent. BC-c. 1 st cent. $A D$ ?). With formulaic entries, the priests report that they had fulfilled the promise they

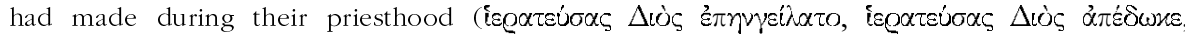

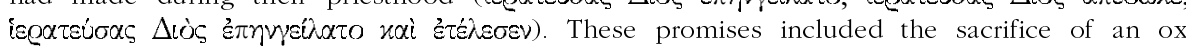

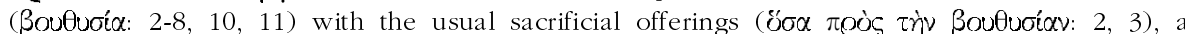

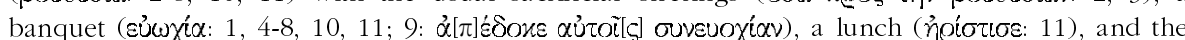

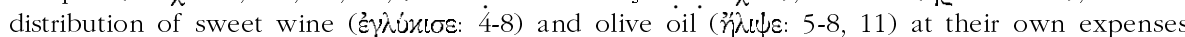
(iónic $\delta \alpha \pi \alpha v_{n}^{\prime}(\alpha \sigma)$ ). [The festival seems to have (occasionally?) included athletic contests, as one may infer from the distribution of olive oil]. The entries were made at the priests' initiative after their term in office. The content of the promise ( $2 \pi x \gamma \gamma \varepsilon \lambda \dot{i} \alpha)$ differed from time to time, but may have been part of the electoral procedure (a kind of summa honoraria) [for this phenomenon $c f$.

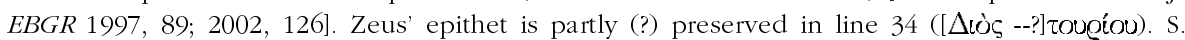
provides numerous parallels for similar lists and evidence for feasts. The other inscriptions from the same site include the posthumous dedication of the statue of a man to the gods by his parents (2, late Hellenistic or early Imperial period) and five funerary imprecations (3-7, 


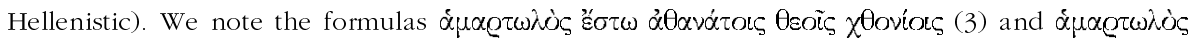

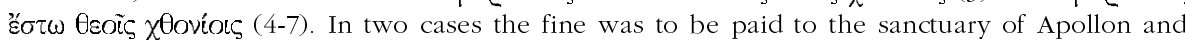

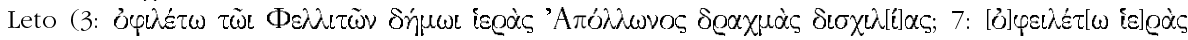

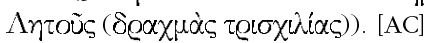

154) N. Sharankov - S. Cherneva-Tiliriyan, "The Life of Ancient Philippopolis in Lucian's Dialogue Runaway", Archaeologia Bulgarica 6.3 (2002), p. 45-61 [SEG LII 705]: In a discussion of the information provided by Lucian's Runaways (165/6 A.D.) on Philippopolis in the 2nd cent. AD, the authors show that the divine persons in the dialogue correspond to contemporary cults known from inscriptions (Apollon, Hermes, Herakles, Orpheus, Zeus; p. 46-48). [AC]

155) J.L. SHEAR, "Prizes from Athens: The List of Panathenaic Prizes and the Sacred Oil", ZPE 142 (2003), p. 87-108 [BE 2004, 138]: After a detailed discussion of two fragments of an inscription listing the prizes presented at the Great Panathenaia ( $I G \mathrm{II}^{2} 2311$, early 4th cent.), S. offers a new critical edition of the preserved text and restorations of the missing parts concerning mainly the musical and equestrian parts of the contest. According to S., the original stele must have been at least $1.122 \mathrm{~m}$ high, listing both the disciplines and the prizes for the victors. $I G \mathrm{II}^{2} 2311$ is the only epigraphical evidence for the recognition of finishers after the victor, and this feature distinguishes the Great Panathenaia from the four Panhellenic games, at least during the 4th cent. On the contrary, the Panathenaic victors' lists of the 2nd cent. record only the winner. The inscription also attests to a major change concerning the sacred oil as the winners' award: At some point in the 380s the eponymous archon seems to have assumed the control over the production of sacred oil. From this period onward the Panathenaic prize amphoras bear the name of the archon. After 312/11 BC, in the course of a new reforms, the eponymous archon was no longer named and the name of other officials, such as the $\tau \alpha \mu i x \varsigma \tau \tilde{i}$

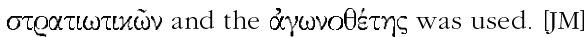

156) A. SIDERIS, "Bronze Drinking Vases Bearing Dedicatory Inscriptions", Eirene 38 (2002), p. 167-201 [SEG LII 1850]: We make a small addition to the summary presented in $E B G R 2002,135$. In an overview of dedicatory inscriptions on metal vases (p. 177-180), S. gives a majuscules copy of a new inscribed bronze phiale of unknown provenance (late 6th cent.; Kunst der Antike 15/06/1998, Basel, 1998, p. $42 \mathrm{n}^{\circ} 102$ ), which attests a new epithet of Athena:

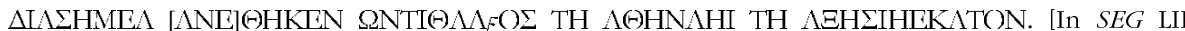

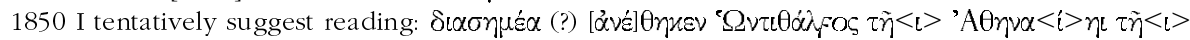

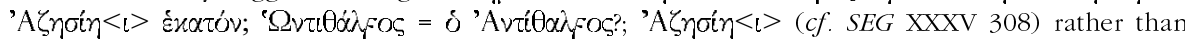
$A<\dot{U}>\xi_{r a i n}<1>$; the mention of Azesia/Auxesia suggests a provenance from Epidauros or Aigina, but this is contradicted by the Ionian forms ('A 1 rvxin, 'AYroir)]. [AC]

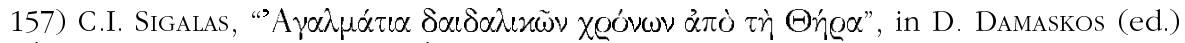

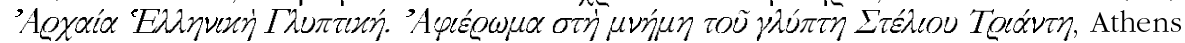
2002, p. 31-36 [SEG LII 787]: Recent excavation at a site outside the acropolis of Thera, originally interpreted as a cemetery (H. DRAGENDORFF, Thera II, Berlin, 1903, p. 291-322), has shown that it was the deposit of a sanctuary founded in the late 8th cent. A graffito on an Archaic Attic kylix (in the Cretan dialect: 'A foc $\delta i \tau x c)$ shows that the sanctuary was dedicated to Aphrodite. This find as well as three Daedalic statuettes suggests close relations between Crete and Thera. Extensive building works were carried out in this sanctuary in the 2nd cent. AD, possibly initiated by the benefactor Ti. Flavius Kleitosthenes (IG XII.3, 326). S. suggests identifying a sanctuary of Eileithyia mentioned in IG XII.3, 326 with this sanctuary of Aphrodite. [cf. $i d$., "Un sanctuaire d'Aphrodite à Théra", Kernos 13 (2000), p. 241-245]. [AC]

158) R. SIMMs, "Agra and Agrai", GRBS 43 (2002/2003), p. 219-229: S. endorses the hypothesis that the expression $2 v$ "A $\gamma \propto \alpha \varsigma$ does not refer to a site, but to the goddess Agra ('in the sanctuary of Agra') - the district Agrai derived its name from the goddess Agra/Agraia ( $c f$. Athena/Athenaia). The cult of Artemis may have supplanted that of Agra, Artemis assuming the name of the older goddess as an epithet (Agrotera). The sanctuary of Agra hosted also the cults of Meter (IG $\mathrm{I}^{3}$ 369), Zeus Meilichios (LSCG 18), Eileithyia (IG $\mathrm{II}^{2} 4682,5099$ ), Demeter, and Kore. 
The Lesser Mysteries of Agrai were probably founded upon the old rites which included a procession and a purification. [AC]

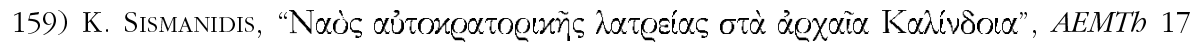
(2003), p. 143-154: During a rescue excavation in 2003 in Kalindoia s. uncovered important architectural members of marble as well as bases and pedestals of monuments, probably statues.

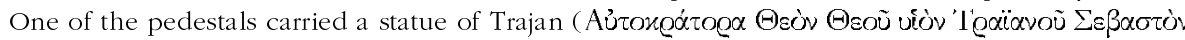
$\dot{\gamma} \pi \hat{c} \lambda(c)$. Based on this text and an honorary decree referring to the cult of Augustus [SEG XXXV 744, $1 \mathrm{AD}$; $c f$. EBGR 1997, 198], and fragments of marble statues of emperors S. suggests that the excavated area belonged to a Sebasteion dedicated to the joint cult of Zeus, the goddess Rome, and the emperor. [JM]

160) M. Stavova, "Administrativna i religiozna nomenklatura v starograckite nadpisi ot cernomorskite kolonii v Balgarija”, in Jubilaeus V, p. 355-361 (in Bulgarian) [SEG LII 656]: S. exploits the epigraphical evidence in an overview of the terminology of the political and religious institutions of the Greek colonies in Thrace and Moesia (especially in Dionysopolis, Mesambria, and Odessos). S. discusses inter alia various cult officials (agonothetes, archiereia, hiera, hiereus, hieronomos, hieropoios, hymnodos, neokoros, panegyriarches, zakoros) and officials cult associations, especially of mystery cults (archimystes, bakcheastes, boukolos, kistaphoros, liknaphoros, thoinites). [AC]

161) R.R.R. SMith, "The Statue Monument of Oecumenius: A New Portrait of a Late Antique Governor from Aphrodisias", JRS 92 (2002), p. 134-156 [SEG LII 1036; BE 2003, 124]: S. publishes the assembled fragments of the statue of the governor of Karia Oecumenius (late 4th cent. AD; $c f . A L A 31$ ). On a newly discovered fragment of the head $\mathrm{S}$. discovered the

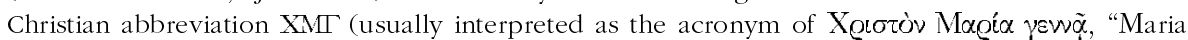
gives birth to Christ"), engraved by a Christian sculptor in a position which was invisible to any ancient spectator, and in such a way as to make it readable only to anyone standing behind it (p. 150-153; for a similar inscription $c f$. ALA 145). Although there is no way we can know for certain why the sculptor engraved this Christian symbol on the head of the statue he was making, S. presents plausible arguments for the assumption that the sculptor's Christian beliefs stood in contrast to those of the governor. It is not certain whether Oecumenius is identical with a governor of Crete by the name of Oecumenius Dositheus Asclepiodotus, who is known to have had connections with the prominent pagan senator Agorius Praetextatus in Rome. Both the governor of Crete and the governor of Caria were men of letters, interested in Latin literature, and that would support this identification, but the governor of Caria could well be a relative, perhaps the son of the governor of Crete, who shared with the father the interest in Latin prose, most probably also the religious beliefs. The honorary epigram for Oecumenius in Aphrodisias is vague with regard to religious beliefs, with the exception of the idea of the purity of the mind, which has deep roots in Greek sacred laws, but was also adopted by Christianity. This graffito may be evidence for the conflict between Christians and pagans in late antique Aphrodisias [cf. EBGR 2002, 20]. [AC]

162) A. Stewart, "Alkamenes at Ephesos and in Athens", ZPE 143 (2003), p. 101-103 [BE 2004, 66]: S. suggests that the sculptor Alkamenes, mentioned in an Ephesian inscription (SEG XLV 1584) that records a dedication to an unknown deity by the enigmatic group of the Naeis, is the famous sculptor of the 5 th cent. The most probable provenance of the dedication is the Artemision; it may be related to the completion of the first great temple of the Ephesian Artemis. According to S., Alkamenes made two herms, the Hermes Propylaios for the Athenian Akropolis and the one for the Ephesian Artemision, which stood on the base dedicated by the Naeis [see also $i d$., "Alkamenes' Two Herms Again", ZPE 145 (2003), p. 107-108]. [JM]

163) J.-Y. Strasser, "Choraules et pythaules d'époque impériale. À propos d'inscriptions de Delphes", BCH 126 (2002), p. 97-42 [SEG LII 501 quater, 511, 528, 529 bis, 530-531]: In a thorough study of the role of flutists in the contests of the Imperial period, S. makes a distinction between the choraulai who accompanied the pantomimes and those who performed compositions for aulos and chorus in contests. S. discusses the career of several 
musicians, presenting new critical editions or prosopographical studies of the relevant inscriptions (IG VII 1776; CIG 1719; SEG XLII 465; F.Delphes III.1, 547, 550; III.4, 478; III.6, 143). He gives an overview of the officials of the Olympic Games in the Roman Empire, who regularly served for

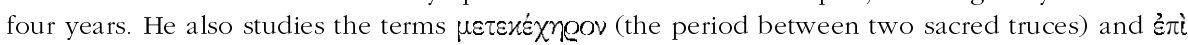
$\tau \tilde{\eta} \varsigma^{\prime}$ 'O $\lambda u \mu \pi \dot{\alpha} \delta \delta \varsigma$ (the period between two Olympic festivals). [AC]

164) J.-Y. STRAsser, "La carrière du pancratiaste Markos Aurélios Démostratos Damas", BCH 127 (2003), p. 251-299: Various inscriptions from Sardeis, Rome, Ephesos, Delphi, and Egypt attest to the remarkable career of the pankratiast Markos Aurelios Demostratos Damas during the reign of Marcus Aurelius and offer invaluable information on the history of the contests he won. S. rejects a connection between two Ephesian inscriptions (I.Ephesos 1160 and 1612) and Demostratos Damas. An inscription in Sardeis (I.Sardis 79 C 8-9) refers to a victory of

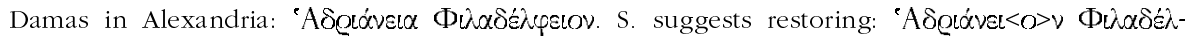
'peเov; the name of this agon was Hadrianeios Philadelpheios. According to S., four fragments of a Delphic inscription (SEG XLII 461) belong to a chronological list of the victories of Demostratos Damas. S. suggests new restorations for all four fragments. [JM]

165) J.-Y. Strasser, "Inscriptions agonistiques de Sidé", EA 35 (2003), p. 63-76: s.

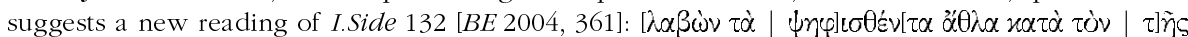

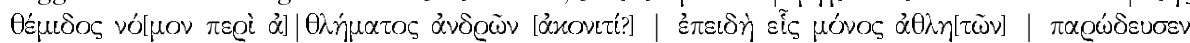
["(the person $\mathrm{X}$, winner in this competition) received the prizes fixed by a decree according to the law of themis for the discipline in the category of men, (without having to fight), since he alone of all the athletes appeared"]. According to $S$. the numbers $T N \Theta$ and $\Sigma(\triangle \Delta$ in two oracular texts on a base dedicated to Apollon (I.Side 134) are cryptic numerological references to the persons (father and son) who received the oracles and dedicated the monument, which was inscribed with a dedicatory inscription and the two oracular texts. [JM]

166) H. TAEubER, "Die Inschriften", JÖAI 72 (2003), p. 263-269: Ed. pr. of an epitaph on a sarcophagus (265-268 n 2, Ephesos, 2nd cent. AD). In his epitaph, Claudius Agathon informs an

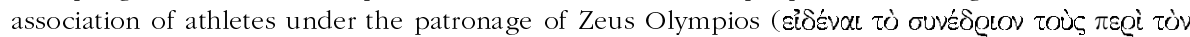

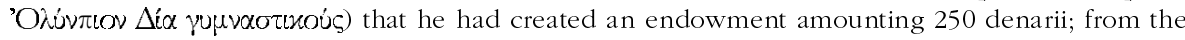
interest, a money distribution was to take place every year on the 8th day of the 10th month, probably in connection with a funerary banquet [on Agathon's birthday]. The recipients, sixty

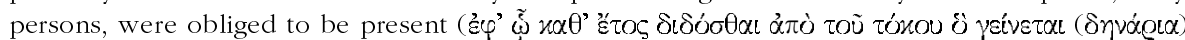

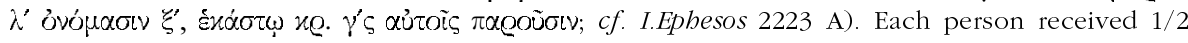
denarius. [The fact that a number of recipients is given implies that the association had a specific number of members]. The association was named after Zeus Olympios, probably after Hadrian's visit in Ephesos and the foundation of the agon Hadriana Olympia (129 AD). [JM]

167) C. TAnriver, "A Dedication to Hosios and Dikaios from Phrygia", EA 36 (2003), p. 29-31 [BE 2004, 62 and 347]: Ed. pr. of an altar dedicated by Aurelios to Hosios and Dikaios in fulfilment of a vow (unknown provenance, after $212 \mathrm{AD}$ ); the gods are represented in relief as standing male figures. The sculptor's signature ("Alexandros of Dokimeion made (this)") suggests a provenance from Phrygia. [JM]

168) C. TAnRiver - M. Yilmaz, "A Dedication to Augustus", EA 35 (2003), p. 46: Ed. pr. of a small altar dedicated to Augustus by the otherwise unattested village of the Olyndondreis

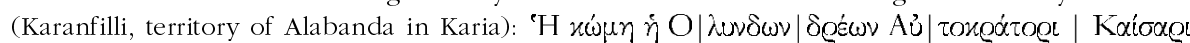

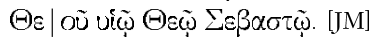

169) I. Tantillo, "Costantino e Helios Pantepoptês: La statua equestre di Termessos", Epigraphica 65 (2003), p. 159-184 [BE 2004, 72]: T. offers a new interpretation of an inscription on a base from Termessos (TAM III.1, 45) which originally supported a rider statue:

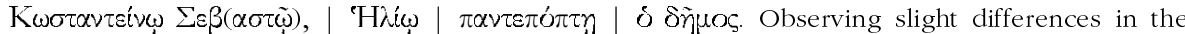
letter forms T. argues that the statue was first dedicated to Helios Pantepoptes; the dedication to emperor Constantine was inscribed later. The only other base for a rider statue in Termessos is a dedication to Augustus (TAM III.1, 36) reused in the theatre of the city in the 2nd cent. AD. The dimensions of the base are quite similar to those of the base for the statue of Helios/Constantine. 
T. suggests that the statue was originally dedicated to Augustus; when the cult of Helios Pantepoptes was introduced to Termessos during the 2nd cent. AD, the rider statue of Augustus was re-dedicated and placed on a newly made base; after AD 325 the rider statue and its base were once more re-dedicated to Constantine simply by adding the name of the emperor above the older dedicatory inscription. [JM]

170) P.J. Thonemann, "Notes on Inscriptions from Konya", EA 36 (2003), p. 87-94 [BE 2004, 368]: T. suggests new readings and restorations of some of the inscriptions kept in the Konya Archaeological Musem (B.H. McLEAN, Greek and Latin Inscriptions in the Konya Archaeological Museum [Regional Epigraphic Catalogues of Asia Minor, IV], London, 2002]. In $n^{\circ} 8$ T.

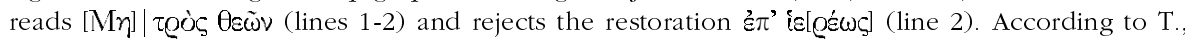

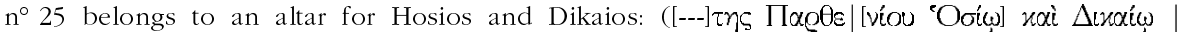

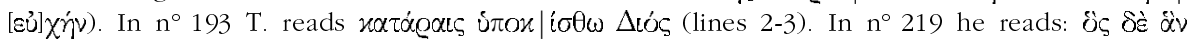

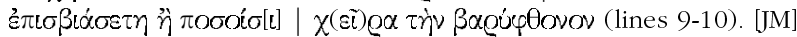

171) S.R. TOKHTAS'Ev, "Ostrakon s poselenija Kosyrka XX Olv́ijskoi chory", Hyperboreus 8 (2002), p. 72-98 [SEG LII 742]: Ed. pr. of an ostrakon with four names (Kozyrka, near Olbia,

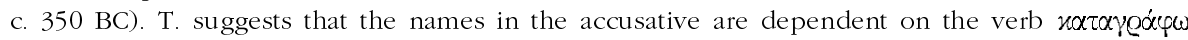
and interprets the text as a defixio. He provides examples of other defixiones written on ostraka (IGDOP 97/98). [AC]

172) M. TRÜMPER, "Das Sanktuarium des 'Établissement des Poseidoniastes de Bérytos' in Delos. Zur Baugeschichte eines griechischen Vereinsheiligtums", BCH 126 (2002), p. 265-303 [SEG LII 758; BE 2004, 71]: On the basis of a detailed analysis of the architectural date and the inscriptions, T. reconstructs the history of the sanctuary of the cult association of the Poseidoniastai of Berytos on Delos, from its construction in ca. $153 \mathrm{BC}$ to the period of its decline after $88 \mathrm{BC}$, making extensive use of the relevant inscriptions (especially I.Délos 1520, 1774, 1778, and 2432) and discussing in detail the introduction of the cult of Thea Rhome (around 130 BC?), her statue made by the Athenian sculptor Menadros, and the Aeci rórqlo! of the Poseidoniastai (Poseidon and Aphrodite/Astarte). [AC]

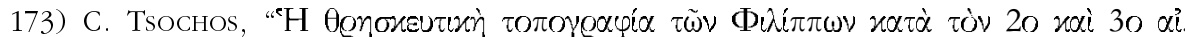
H.X.", AEMTh 17 (2003), p. 71-85: Based on the archaeological evidence and the significant epigraphic material (mainly Latin inscriptions), T. presents a panorama of the religious topography of Philippoi in the 2nd and 3rd cent. AD. The so-called East Temple on the Roman agora can be identified as a building for the cult of the emperor (cf. Philippi II 208, and 231) [EBGR 2002, 121]. The number of inscriptions referring to the cult of Jupiter is strikingly small, while at present we lack epigraphic evidence for the cult of Juno or Minerva. Latin and Greek inscriptions attest to the existence of a Dionysiac thiasos (Philippi II 535). According to T. the cult of the Egyptian deities belonged to the most important of the city, although the number of inscriptions concerning the cult of Isis and Sarapis is rather small [see EBGR 2002, 148]. Reliefs and inscriptions from the city and its territory attest to the existence of cults for Artemis, Liber Pater, the Thracian Rider, and Silvanus. [JM]

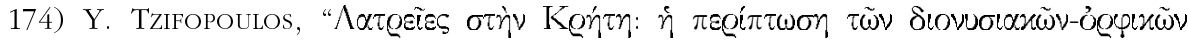
$\dot{\varepsilon} \lambda \alpha \sigma \mu \alpha \tau \tau \omega \nu "$, in Latreies, p. 147-171: T. gives an overview of the recent research on the Dionysiac-Orphic mysteries, focusing in particular on the relevant texts from Crete (SEG XLVIII 1227; I.Cret. II,xii 31a and 31 bis). The Cretan texts imply the existence of a mystery cult in Crete (cf. I.Cret. I,xxiii 3), especially in the Idaean Cave and its vicinity (cf. EBGR 1990, 54). [AC]

175) R. van Bremen, "Ptolemy at Panamara", EA 35 (2003), p. 9-14 [BE 2004, 315]: Ed. pr. of a fragment of an honorific decree (Panamara, 3rd cent.), from which v.B. infers that Panamara was a Ptolemaic possession in the 270s. The privileges of the sanctuary at Panamara (cf. Labraunda III.2, 44 line 2) were probably granted before the early 260s; the asylia renewed by the priest Leon after 167 BC (I.Stratonikeia 7) must have been granted first by a Ptolemaic king. Line 3 mentions the month Apellaios. [JM] 
176) R. van Bremen, "Notes on Some New Inscriptions from Lagina", EA 35 (2003), p. 15-19 [BE 2004, 316]: 1) An inscription found in Lagina (SEG XLVII 1575; EBGR 1997, 326) refers to a dedication by Tib. Flavius Sabinianus to the deity he served as priest for life ( $\delta$ เ̀̀ Biou). In the ed. pr. M.C.. SAHIN identifed the deity as Zeus Papamaros. But since the priesthood of Zeus Panamaros was an annual office, v.B. rightly assumes that the dedication was made to a deity

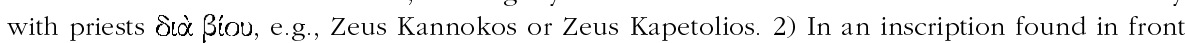
the temple at Lagina (1st cent.) SAHIN restored the office of the kleidophoros (EBGR 1999, 214;

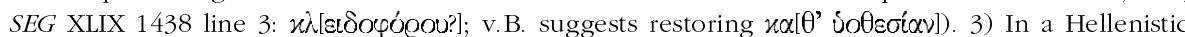
decree from Lagina (SEG XLVII 1588) SAHIN identified the stephanephoros as Apollodotos, son of Chrysaor, of Koraia. According to v.B. there is no need to restore a demotic and the identification is uncertain [but attractive and, despite v.B.'s objections, possible]. [JM]

177) J. Vihonen - Z.T. Fiema, "Greek and Latin Inscriptions", in Z.T. Fiema et al., The Petra Church, Amman 2001, p. 342-345 [SEG LI 2074; BE 2003, 609; AE 2001, 19801981]: Ed. pr. of two dedications to Aphrodite (Petra, 2nd/3rd cent.; p. $342 f . \mathrm{n}^{\mathrm{os}} 1$ and 4 ). The first

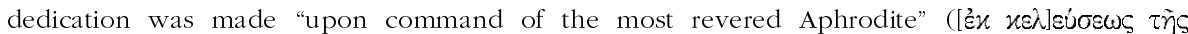

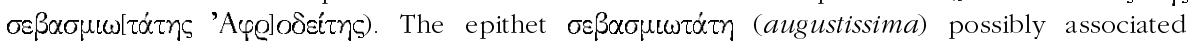
Aphrodite with the emperor cult. The second dedication is addressed to Thea Aphrodite. [AC]

178) E. Vikela, "Continuity in Greek Religion: The case of Zeus Cretagenes", Cretan Studies 8 (2003), p. 199-216: Based on the archaeological evidence, the reference to Dictaean Zeus in the Linear B tablets from Knossos, and the hymn to the Kouros from Palaikastro (2nd-3rd cent. $\mathrm{AD}$ [but perhaps composed already in the 4th cent.; for a new edition and discussion see $E B G R$ 2001, 62]), V. studies the possibility of a continuity in the cult of Zeus Cretagenes from the Bronze Age to historical times. [Despite the indications for such a continuity, V.'s assumptions often go beyond what the evidence would allow]. [JM]

179) D. Viviers, "Le bouclier signé du Trésor de Siphnos à Delphes: 'Régions stylistiques' et ateliers itinérants ou la sculpture archaïque face aux lois du marché", in C. MÜLler - F. Prost (eds), Identités et cultures dans le monde méditerranéen antique, Paris, 2002, p. 53-85 [SEG LII 538]: According to a new restoration of the metrical sculptor's

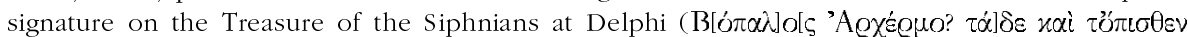
छ $\pi$ cis; $C E G$ 499, c. 530-535) the sculptor of the north frieze of the Treasure was Boupalos of Chios. V. discusses in detail the stylistic identity of the sculptors responsible for the Siphnian treasure and the organisation of the work. [AC]

180) R. WAChter, "Ariston weihte drei Töchter", ZPE 142 (2003), p. 53-63: Ed. pr. of a small bronze tablet with a dedicatory inscription in a private collection in the U.S.A. The text on

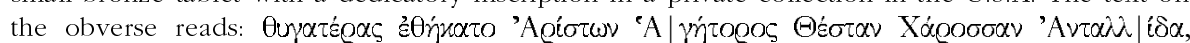

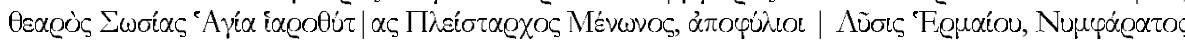

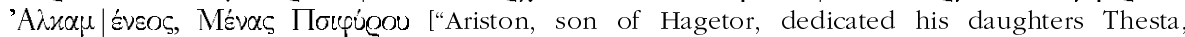
Charossa, and Antallis. Sosias, son of Hagias, was theoros, the bierothytes was Pleistarchos, son of Menon, the representatives of the phylai were Lysis, son of Hermaios, Nympharatos, son of

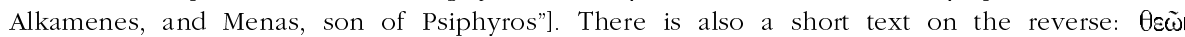

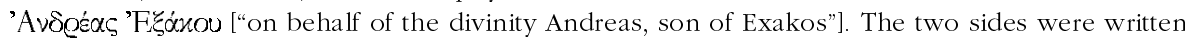
by different scribes. Holes at the right and left part indicate that the bronze tablet was attached to a larger object. W. shows that the inscription dates to the late 5 th cent. and originates from one of the Sicilian colonies of Rhodos. The inscription mentions three offices: Esx@óc (not an envoy, but

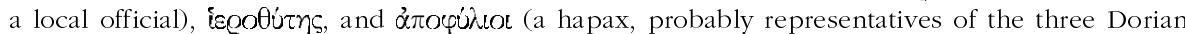
tribes). W. interprets the text of the inscription literally, assuming that Ariston dedicated his three daughters to Athena, so that they serve as priestesses, perhaps in a rite de passage. [An alternative hypothesis is that Ariston dedicated statues or statuettes of his daughters; the bronze tablet was attached to the base; the inscription on the back side of the tablet would simply mean that a representative of the sanctuary accepted (and registrated) the votive offering on behalf of the deity. The theoros and the apophylioi may represent a delegation of officials who accompanied the maidens (or the statues) to an important sanctuary]. [JM] 
181) B. WAGNER-HASEL, "Kommunikationswege und die Entstehung überregionaler Heiligtümer: das Fallbeispiel Delphi”, in Stuttagrter Kolloquium 7, p. 160-180 [SEG LII 528]: The sanctuary of Apollon at Delphi is located on important routes used by transhumant shepherds. The cult activities (meetings of the Amphictyonic council, the coming of Apollon to Delphi) correspond to the beginning and the end of the seasonal movement of flocks. One of the primary functions of the sacred land was its use for pasture (e.g., F.Delphes III.2, 36; III.4, 77 and 282; Syll. ${ }^{3}$ 636). The Amphictyonic council paid great attention to the protection of the roads (CID I 10), which corresponds to one of the functions of Apollon Agyieus. Based on these observations, W.-H. makes a strong case for the assumption that the development of Apollon's sanctuary into a supra-regional cult center is connected with transhumance. The importance of pastoral activities may explain the supra-local significance also of the sanctuaries at Olympia and Dodona. [AC]

182) H.-U. Wiemer, "Käufliche Priestertümer im hellenistischen Kos", Chiron 33 (2003), p. 263-310: W. offers an invaluable overview of the practice of selling priestly offices based exclusively on the epigraphic material (cf. DiOn. HAL., Ant. Rom. II 21, 3). W. concentrates on the evidence from Kos [cf. EBGR 2000, 151 and 2001, 139] but makes ample use of examples from Ionia and Karia. After showing that the term diagrapha (without any additional specification) was used to designate documents concerning the selling of priesthoods, W. discusses the procedures behind and the structure of such documents, examining also the groups interested in these transactions: while the polis aimed at a high profit, the persons who bought a priestly office were not only interested in profit, but also in prestige. An interesting aspect of the Koan diagraphai is that they prescribed very often pre-defined sacrifices to be made by specific groups of persons; e.g., the Koan monarchos had to sacrifice together with the hieropoioi a sheep to Hermes Enagonios amounting to 30 drachmai (IscrCos ED 145A, lines 12-18, 2nd cent.). W. suggests that such strict regulations aimed not only at a better systematisation of sacrificial practices, but also at an assurance of the income of those who were to buy the respective priesthood. Such regulations did not exist for lucrative priesthoods, e.g., for the cult of Dionysos Thyllophoros (LSCG 166). In the closing section of his study W. emphasises the fact that the selling of priesthoods on Kos is apparently a phenomenon of the Hellenistic era connected to the enormous expenditures of that period. [JM]

183) H.-U. Wiemer, "Die koische Opfergebotsliste Syll.3 1000 - diagrapha oder nomos?", ZPE 145 (2003), p. 117-122 [BE 2004, 239]: W. discusses briefly the well known Koan inscription listing numerous groups of persons (no less than 26) obliged to sacrifice inter alia to Poseidon and the nymphs Kos and Rhodos (Syll. ${ }^{3} 1000=$ LSCG 168). In its first part (lines $1-15)$, the inscription lists 15 groups of tenants of public property, without a specific reference to the kind of sacrificial victim or the name of the divinity. The second part (lines 16-24) lists 9 groups and their obligation to sacrifice predefined victims to Poseidon, Kos, and Rhodos. A comparison of this text with the diagrapha for Hermes Enagonios (IscrCos ED 145) leads W. to the conclusion that Syll. ${ }^{3} 1000$ is a sacred law for the Koan cults of Poseidon, Kos, and Rhodos; these divinities must have been the recipients of the sacrifices also in the first part of the inscription. [JM]

184) P. WILson, The Athenian Institution of the Khoregia. The Chorus, the City, and the Stage, Cambridge, 2000 [SEG LI 9, 45-46]: W.'s thorough analysis of the choregia in Athens, based on an analysis of many inscriptions, is a major contribution to the study of dramatic and choral performances at Athenian festivals. W. also collects the evidence for choregoi in other cities (p. 279-302 and 309f.) and treats many relevant subjects, such as competition in euandria and torch-races (p. 35-38) and the institution of architheoria (44-46). [AC]

185) M. WÖRrLe, "Inschriften von Herakleia am Latmos III. Der Synoikismos der Latmioi mit den Pidaseis", Chiron 33 (2003), p. 121-143 [BE 2004, 308]: W. studies anew a decree found in Herakleia and concerning regulations about the synoikismos of the polis of the Latmoi with Pidasa (Herakleia, c. 323-313 BC; SEG LXVII 1563). The first sixteen lines of the preserved text regulate inter alia religious affairs. The timouchoi (a board of officials) were to sacrifice to Athena, the patron of the Latmioi, so that the new city might live in concord (lines 2-4: $\pi$ eoc- 


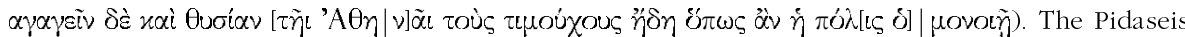
should have the right to participate equally to any religious activity in the new city (lines 10-11:

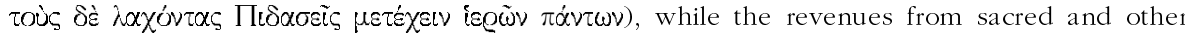

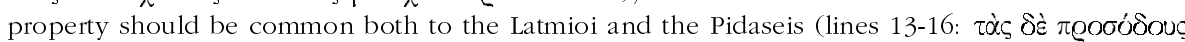

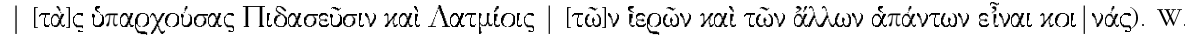
shows that the month Dios (line 18) is to be identified with the Macedonian month. It seems that the Ionian calendar was (re)introduced at a later date, since only Ionian month names are known in Herakleia. The decree was to be sealed through an oath in the agora (of the Latmioi), during which a bull and a swine were to be sacrificed (lines 31f.: $\tau$ xú Stelai with the decree were to be published in the sanctuary of Zeus Lambraundos and in the sanctuary of Athena in Latmos (lines 33-36). The Latmioi were to take an official oath invoking Zeus, Ge, Helios, Poseidon, Athena Areia, and the Tauropolos (lines 38f.). A similar oath by the Pidaseis must have followed in the lost section of the inscription. W. plausibly argues that the initiative for the synoikismos was taken by Asandros, whose name was given to a new phyle (line 6: Asandris). [JM]

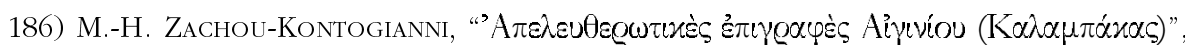
Egnatia 7 (2003), p. 29-49: Z.-K. studies several manumission inscriptions from Aiginion (modern Kalambaka). We remark the theophoric names Apollonios (IG IX.2, 327 C) and Asklapon ( $I G$ IX.2, 324 B), and the month names Agagylios ( $I G$ IX.2, 327 B2), Hermaios (IG IX.2, $324 \mathrm{~B} ; 325 \mathrm{~B}$ ), and Hippodromios (IG IX 2, $325 \mathrm{~A}$ and 326). [JM]

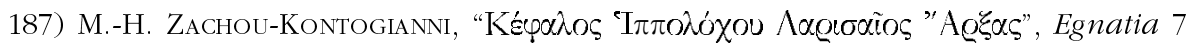
(2003), p. 9-28: Z.-K. reconstructs the career and the family tree of Kephalos, son of Hippolochos, from Larissa, an important general of the Thessalian koinon in the Augustan period. His adopted son Hippolochos was married to a priestess honored by the demos of Larissa ( $A D$ $1927 / 28$, p. 55 f. $n^{\circ} 1$ ). His natural son Hegesaretos won a special horse race during the

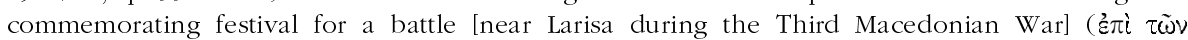

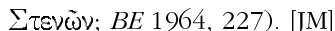

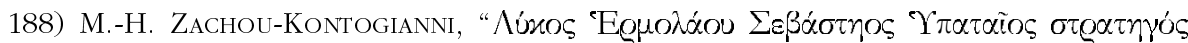

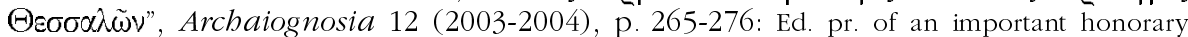
inscription "found" in the courtyard of a private house in the village of Hypate. The inscription refers to a hitherto unknown general of the Thessalian koinon, Lykos Sebasteos, son of

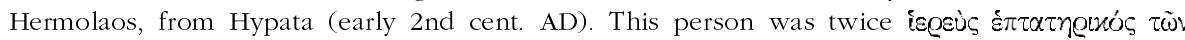

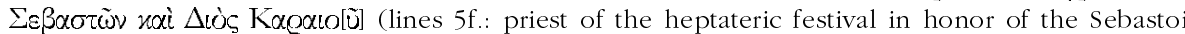

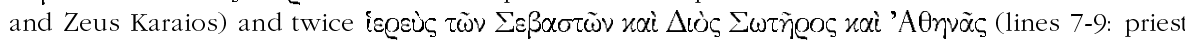
of the Sebastoi, Zeus Soter, and Athena). The word Sebastos is to be associated with the reorganisation of the Delphic Amphictyony by Augustus, as already suggested by L. Robert. [JM]

189) R. ZIEGLER, "Asklepioskult und Kaiserkult im kilikischen Aigeai um die Mitte des 3 Jahrhunderts n. Chr.", Olba 7 (2003), p. 205-217: Based mainly on the numismatic material, but making also use of the epigraphical and the archaeological evidence, Z. argues that the cult of the Roman emperors and their families at Aigeai (Kilikia) was strongly interconnected to that of Asklepios. Inscriptions on coins of Gordian III, Herennius Etruscus, and Hostilian characterise

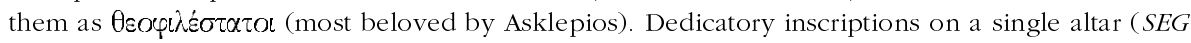
XXXII 1312; XXXVII 1249) addressed to Gordian III as Augustus, the deified Gordian I and II

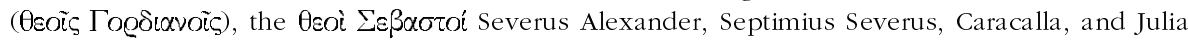

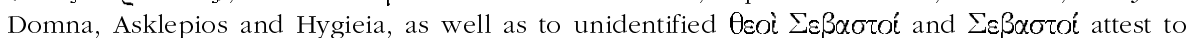
the conjunction of the emperor's cult to that of Asklepios. [JM]

190) A. Zournatzi, "A Goldsmith's Dedication: New Evidence for the Cult of Asclepius at Trajanopolis", Ancient East and West 2.2 (2003), p. 325-347: Ed. pr. of a small altar dedicated to Theos Asklepios and Hygieia by a goldsmith (Traianopolis, 2nd/3rd cent. AD). The cult of these deities was attested through coins of Traianopolis. This cult is connected with the thermal spring in this area. A boundary stone of sacred land, carved on a rock by the foothill of

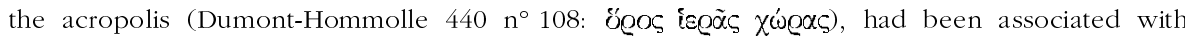


mainland holdings of the sanctuary of the Great Gods of Samothrake (cf. IG XII 8 pp. 39/40), but it may refer to the sacred land of the sanctuary on the hill of Agios Georgios [but then one would

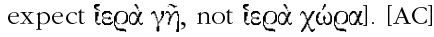

\section{Angelos CHANIOTIS}

Seminar für Alte Geschichte und Epigraphik Marstallhof 4

D - 69117 Heidleberg

angelos.chaniotis@urz.uni-heidelberg.de

\section{Joannis MYLONOPOULOS}

Theorie und Geschichte antiker Religionen Religionswissenschaft Philosophische Fakultät, Postfach 900221 D - 99105 Erfurt joannis.mylonopoulos@uni-erfurt.de 